\title{
Mechanistic Studies of Ethylene Hydrophenylation Catalyzed by Bipyridyl Pt(II) Complexes
}

\author{
Bradley A. McKeown, ${ }^{\S}$ Hector Emanuel Gonzalez, ${ }^{\ddagger}$ Max R. Friedfeld, ${ }^{\S}$ T. Brent Gunnoe, ${ }^{*, \S}$ \\ Thomas R. Cundari, ${ }^{* \neq}$ and Michal Sabat ${ }^{\S}$ \\ $\S^{\S}$ Department of Chemistry, University of Virginia, Charlottesville, Virginia 22904, United States \\ ${ }^{\ddagger}$ Center for Advanced Scientific Computing and Modeling (CASCaM), Department of Chemistry, University of North Texas, \\ Denton, Texas 76203, United States
}

S Supporting Information

ABSTRACT: Cationic platinum(II) complexes $\left[\left({ }^{t} \mathrm{bpy}\right) \mathrm{Pt}(\mathrm{Ph})\right.$ $(\mathrm{L})]^{+}\left[{ }^{t}\right.$ bpy $=4,4^{\prime}$-di-tert-butyl-2,2'-bipyridyl; $\mathrm{L}=\mathrm{THF}, \mathrm{NC}_{5} \mathrm{~F}_{5}$, or NCMe] catalyze the hydrophenylation of ethylene to generate ethylbenzene and isomers of diethylbenzene. Using ethylene as the limiting reagent, an $89 \%$ yield of alkyl arene products is achieved after $4 \mathrm{~h}$ at $120^{\circ} \mathrm{C}$. Catalyst efficiency for ethylene hydrophenylation is diminished only slightly under aerobic conditions. Mechanistic studies support a reaction pathway that involves ethylene coordination to $\mathrm{Pt}(\mathrm{II})$, insertion of ethylene into the $\mathrm{Pt}-$ phenyl bond, and subsequent metal-mediated benzene $\mathrm{C}-\mathrm{H}$ activation. Studies of stoichiometric benzene $\left(\mathrm{C}_{6} \mathrm{H}_{6}\right.$ or $\left.\mathrm{C}_{6} \mathrm{D}_{6}\right) \mathrm{C}-\mathrm{H} / \mathrm{C}-\mathrm{D}$ activation by $\left[\left({ }^{t} \mathrm{bpy}\right) \mathrm{Pt}\left(\mathrm{Ph}-d_{n}\right)-\right.$ $(\mathrm{THF})]^{+}(n=0$ or 5$)$ indicate a $k_{\mathrm{H}} / k_{\mathrm{D}}=1.4(1)$, while comparative rates of ethylene hydrophenylation using $\mathrm{C}_{6} \mathrm{H}_{6}$ and $\mathrm{C}_{6} \mathrm{D}_{6}$ reveal $k_{\mathrm{H}} / k_{\mathrm{D}}=1.8(4)$ for the overall catalytic reaction. DFT calculations suggest that the transition state for benzene $\mathrm{C}-\mathrm{H}$ activation is the highest energy species along the catalytic cycle. In $\mathrm{CD}_{2} \mathrm{Cl}_{2}$, [( $\left.\left.{ }^{t} \mathrm{bpy}\right) \mathrm{Pt}(\mathrm{Ph})(\mathrm{THF})\right]\left[\mathrm{BAr}_{4}^{\prime}\right]\left[\mathrm{Ar}^{\prime}=3,5\right.$-bis(trifluoromethyl)phenyl $]$ reacts with ethylene to generate $\left[\left({ }^{t}\right.\right.$ bpy $\left.) \mathrm{Pt}\left(\mathrm{CH}_{2} \mathrm{CH}_{2} \mathrm{Ph}\right)\left(\eta^{2}-\mathrm{C}_{2} \mathrm{H}_{4}\right)\right]\left[\mathrm{BAr}_{4}^{\prime}\right]$ with $k_{\text {obs }}=1.05(4) \times 10^{-3} \mathrm{~s}^{-1}\left(23{ }^{\circ} \mathrm{C},\left[\mathrm{C}_{2} \mathrm{H}_{4}\right]=0.10(1) \mathrm{M}\right)$. In the catalytic hydrophenylation of ethylene, substantial amounts of diethylbenzenes are produced, and experimental studies suggest that the selectivity for the monoalkylated arene is diminished due to a second aromatic $\mathrm{C}-\mathrm{H}$ activation competing with ethylbenzene dissociation.

\section{INTRODUCTION}

The formation of alkyl arenes by transition metal-mediated addition of aromatic $\mathrm{C}-\mathrm{H}$ bonds across unsaturated $\mathrm{C}=\mathrm{C}$ bonds, olefin hydroarylation, is of considerable importance (eq 1). ${ }^{1}$ Several billion pounds of alkyl aromatics are produced annually and used for plastics, fuels, pharmaceuticals, and surfactants. Historically, Friedel-Crafts catalysts have been used to prepare alkyl arenes including the large-scale synthesis of ethylbenzene, cumene, and long-chain alkyl arenes. ${ }^{2}$ However, such systems suffer from drawbacks that are inherent to the mechanism by which the catalysts function. ${ }^{3}$ For example, the use of a Brønsted acid cocatalyst, often HF, can be problematic due to its corrosive nature, and recycling of the catalyst is not possible due to catalyst decomposition upon neutralization of the acidic solution during product isolation. In addition, polyalkylation is common with Friedel-Crafts catalysts, and the production of monoalkylated arenes in high yield on an industrial scale often requires a second step with a transalkylation catalyst. ${ }^{3-6}$ Furthermore, with Friedel-Crafts catalysts, the selective production of linear alkyl arenes from $\alpha$-olefins is not possible. The synthesis of linear alkyl arenes requires a Friedel-Crafts acylation followed by Clemmenson or Wolff-Kishner reduction. Finally, achieving 1,2-, 1,3-, or 1,4-selectivity for the preparation of dialkyl benzenes is a challenge with Friedel-Crafts-type catalysts. Solid-state catalysts, largely based on zeolite materials, have provided improvements, but these catalysts function by the same general mechanism as traditional Friedel-Crafts catalysts and have some of the same limitations. ${ }^{3-11}$ Despite the advancements with zeolite-based catalysts, it has been estimated that approximately $40 \%$ of global ethylbenzene is still produced using processes with aluminum-based catalysts. ${ }^{5}$

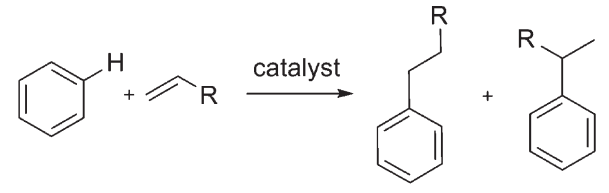

The development of transition metal-based catalysts for the hydroarylation of olefins that operate by olefin insertion into

Received: June 30, 2011

Published: November 08, 2011 
metal-aryl bonds followed by aromatic $\mathrm{C}-\mathrm{H}$ activation offers a complementary route to alkyl arenes. It is possible that such catalysts can be tuned to achieve selectivity including monoversus polyalkylation, linear versus branched alkyl chains, as well as regioselective formation of dialkylated aromatic substrates. Several transition metal systems have been demonstrated to catalyze olefin hydroarylation, but substrate scope is often limited to heteroaromatic compounds or substrates that possess at least one activating group. ${ }^{1,12-17}$ Homogeneous catalysts that initiate olefin hydroarylation of unactivated substrates (i.e., hydrocarbons) have been reported, but these are limited to a few catalyst systems. ${ }^{18-26}$

Despite the importance of aromatic alkylations, detailed mechanistic studies of transition metal catalysts that are active for conversion of alkenes and arenes to alkyl arenes remain relatively rare. ${ }^{18,19,21,26-28} \mathrm{Ir}(\mathrm{III})$ systems of the type (acac) $2^{-}$ $\operatorname{Ir}(\mathrm{Ph})(\mathrm{L})\left(\mathrm{acac}=\kappa^{2}-\mathrm{O}, \mathrm{O}\right.$-acetylacetonate, $\mathrm{L}=\mathrm{H}_{2} \mathrm{O}$ or pyridine $)$ have been studied by Matsumoto et al. and Oxgaard et al. ${ }^{20,28}$ Goldberg and co-workers have reported that (dmpp)PtMe $\mathrm{Pl}_{3}$ [dmpp $=3,5$-dimethyl-2-(2-pyridyl)pyrrolide $]$ successfully catalyzes olefin hydrophenylation to yield alkyl benzenes. ${ }^{21}$ Tilley, Bell, and Karshtedt found that a $\mathrm{Pt}-\mathrm{Ag}$ catalyst system and $\mathrm{Pt}$ (II) catalysts supported by pyridyl-pyrrolyl ligands initiate norbornene hydroarylation, but the observed product selectivity suggests the possibility of a Friedel-Crafts-type pathway. ${ }^{22,29}$ Particularly germane is a recent study that reveals catalytic olefin hydroarylation using $\mathrm{Pt}$ (II) triflate salts likely proceeds by formation of triflic acid, which serves as the active catalyst. ${ }^{30}$

Our groups reported a series of studies on $\mathrm{TpRu}(\mathrm{L})(\mathrm{NCMe})$ $(\mathrm{Ph})\left[\mathrm{Tp}=\right.$ hydridotris (pyrazolyl)borate, $\mathrm{L}=\mathrm{CO}, \mathrm{PMe}_{3}, \mathrm{P}(\mathrm{N}-$ pyrrolyl $)_{3}$, or $\left.\mathrm{P}\left(\mathrm{OCH}_{2}\right)_{3} \mathrm{CEt}\right]$ catalysts for olefin hydroarylation. ${ }^{18,19,23-26,31}$ The primary focus has been to elucidate the effect of the donor and steric properties of the ligand $L$ on the key steps of the catalytic cycle (i.e., olefin insertion and aromatic/ olefin $\mathrm{C}-\mathrm{H}$ activation). ${ }^{19}$ In an effort to understand more broadly transition metal catalyzed olefin hydroarylation, we have begun to probe structure/activity relationships for catalysts outside the octahedral $/ \mathrm{d}^{6}$ motif. Platinum(II) seemed well suited for this transformation as it is known to readily activate $\mathrm{C}-\mathrm{H}$ bonds as well as undergo olefin insertion. ${ }^{32-42}$ In a preliminary communication, ${ }^{43}$ we reported that in situ chloride removal from $\left({ }^{t}\right.$ bpy) $\mathrm{Pt}(\mathrm{Ph}) \mathrm{Cl}$ ( ${ }^{t}$ bpy $=4,4^{\prime}$-di-tert-butyl-2,2'-bipyridyl) using $\mathrm{NaBAr}_{4}^{\prime}\left[\mathrm{Ar}^{\prime}=3,5\right.$-bis(trifluoromethyl)phenyl $]$ provides a catalyst for olefin hydroarylation. Herein, we report a more detailed experimental/computational investigation of catalytic hydrophenylation of ethylene by $\left[\left({ }^{t} \text { bpy }\right) \mathrm{Pt}(\mathrm{Ph})(\mathrm{L})\right]^{+}\left(\mathrm{L}=\mathrm{NCMe}, \mathrm{NC}_{5} \mathrm{~F}_{5}\right.$ or THF) complexes in an effort to delineate the reaction mechanism and develop a better understanding of the individual steps in the catalytic cycle.

\section{RESULTS AND DISCUSSION}

Catalytic Hydrophenylation of Ethylene. The complex $\left[\left({ }^{t} \mathrm{bpy}\right) \mathrm{Pt}(\mathrm{Ph})(\mathrm{THF})\right]\left[\mathrm{BAr}^{\prime}{ }_{4}\right](\mathbf{1})$ has been isolated in $93 \%$ yield from the reaction $\left(-60{ }^{\circ} \mathrm{C}\right)$ of $\left({ }^{t} \mathrm{bpy}\right) \mathrm{Pt}(\mathrm{Ph})_{2}$ with $\mathrm{HBAr}_{4}^{\prime}$ in tetrahydrofuran. In $\mathrm{CD}_{2} \mathrm{Cl}_{2}$, the ${ }^{1} \mathrm{H}$ and ${ }^{13} \mathrm{C}$ NMR spectra of $\mathbf{1}$ reveal inequivalent pyridyl groups, and the resonances for coordinated THF ( ${ }^{1} \mathrm{H}$ NMR) are observed as broad multiplets at 4.14 and $1.86 \mathrm{ppm}$. From complex 1, $\left[\left({ }^{t} \mathrm{bpy}\right) \mathrm{Pt}(\mathrm{Ph})(\mathrm{L})\right]^{+}$ variants can be prepared by substitution of THF with other ligands. For example, stirring complex 1 in neat perfluoropyridine or acetonitrile yields the complexes $\left[\left({ }^{t} \mathrm{bpy}\right) \mathrm{Pt}(\mathrm{Ph})\left(\mathrm{NC}_{5} \mathrm{~F}_{5}\right)\right]$ $\left[\mathrm{BAr}_{4}^{\prime}\right]$ (2) and $\left[\left({ }^{t} \mathrm{bpy}\right) \mathrm{Pt}(\mathrm{Ph})(\mathrm{NCMe})\right]\left[\mathrm{BAr}_{4}^{\prime}\right]$ (3) (eq 2).

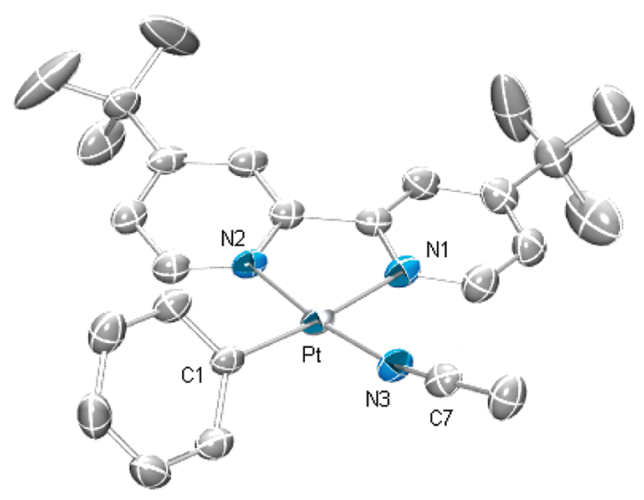

Figure 1. ORTEP of $\left[\left({ }^{t} \mathrm{bpy}\right) \mathrm{Pt}(\mathrm{NCMe})(\mathrm{Ph})\right]\left[\mathrm{BAr}^{\prime}{ }_{4}\right]$ (3) (50\% probability; $\mathrm{H}$ atoms and $\mathrm{BAr}^{\prime}{ }_{4}$ anion omitted for clarity). Selected bond lengths ( $\AA$ ): Pt-N1 2.092(4), Pt-N2 2.000(4), Pt-N3 1.969(4), $\mathrm{Pt}-\mathrm{C} 12.004(5)$. Selected bond angles $\left({ }^{\circ}\right)$ : N1-Pt-N2 79.3(2), $\mathrm{C} 1-\mathrm{Pt}-\mathrm{N} 3$ 88.3(2), Pt-N3-C7 169.7(4).

A crystal of complex 3 suitable for an X-ray diffraction study was grown (Figure 1). The N1-Pt-N2 bond angle is compressed to $79.3(2)^{\circ}$ relative to the ideal $90^{\circ}$ bond angles, which is characteristic of $\mathrm{Pt}(\mathrm{II})$ bipyridyl and diimine complexes. ${ }^{35,44,45} \mathrm{The} \mathrm{Pt}-\mathrm{N} 2$ bond is $0.09 \AA$ shorter than the $\mathrm{Pt}-\mathrm{N} 1$ bond, indicative of a greater trans influence of the phenyl ligand relative to acetonitrile.

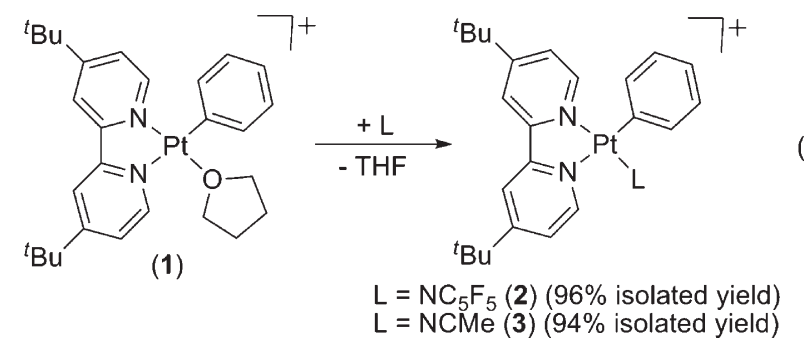

We probed complexes $\mathbf{1}-\mathbf{3}$ as catalyst precursors for the hydrophenylation of ethylene. Heating a benzene solution of 1, 2, or 3 in the presence of ethylene results in the production of ethylbenzene and diethylbenzenes (Table 1). At $100{ }^{\circ} \mathrm{C}$ under $0.1 \mathrm{MPa}$ of ethylene, a solution of $0.025 \mathrm{~mol} \% 1$ (relative to benzene) results in 15.7 turnovers (TO) of ethylbenzene and 3.6 TO of diethylbenzenes after $4 \mathrm{~h}$, corresponding to a turnover frequency (TOF) of $1.3 \times 10^{-3} \mathrm{~s}^{-1}$ (the formation of diethylbenzene is counted as a single catalytic TO; unless otherwise noted, all TOFs are calculated based on product after $4 \mathrm{~h}$ of reaction). After $16 \mathrm{~h}, 63.5 \mathrm{TO}$ (ethylbenzene and diethylbenzenes) were observed. A solution of $1\left(0.04 \mathrm{M}, \mathrm{C}_{6} \mathrm{D}_{6}\right)$ was pressurized with ethylene $(0.1 \mathrm{MPa})$ and monitored by ${ }^{1} \mathrm{H} \mathrm{NMR}$ at $80{ }^{\circ} \mathrm{C}$. Ethylbenzene was produced, and $\left[\left({ }^{t}\right.\right.$ bpy $) \mathrm{Pt}\left(\mathrm{CH}_{2^{-}}\right.$ $\left.\mathrm{CH}_{2} \mathrm{Ph}\right)\left(\eta^{2}-\mathrm{C}_{2} \mathrm{H}_{4}\right]^{+}$was the only Pt complex observed by ${ }^{1} \mathrm{H}$ NMR spectroscopy during the catalytic reaction. The catalysis appears to tolerate aerobic conditions. Setting up the reaction of benzene and ethylene $\left(100{ }^{\circ} \mathrm{C}, 0.025 \mathrm{~mol} \% \mathrm{1}\right)$ on the benchtop (in air) resulted in 17.4 and 55.7 total TO after 4 and $16 \mathrm{~h}$, respectively (compared to 19.3 and 63.5 total TO for the reaction prepared under a dinitrogen atmosphere). Using a calibrated gas buret, a catalytic reaction with a known quantity of ethylene $(0.03$ $\mathrm{MPa}, 4.2 \mathrm{mmol}$ ) as the limiting reagent was arranged. Heating the reaction mixture at $120{ }^{\circ} \mathrm{C}$ for $4 \mathrm{~h}$ resulted in the production of 119.3 TO of ethylbenzene, diethylbenzenes, and styrene, which corresponds to an $89 \%$ yield (eq 3 ). In this reaction, since 
Table 1. Catalytic Hydrophenylation of Ethylene Using Complexes 1-3 As Catalysts ${ }^{a}$

\begin{tabular}{|c|c|c|c|c|c|c|}
\hline Catalyst $^{\mathrm{a}}$ & & & & & $o: m: p^{\mathrm{b}}$ & $\begin{array}{c}\mathrm{TOF}^{\mathrm{c}} \\
\left(10^{-3} \mathrm{~s}-1\right.\end{array}$ \\
\hline$\left[\left({ }^{t} \mathrm{bpy}\right) \mathrm{Pt}(\mathrm{Ph})(\mathrm{THF})\right]\left[\mathrm{BAr}_{4}^{\prime}\right] \quad(\mathbf{1})$ & $\begin{array}{c}15.7^{\mathrm{d}} \\
(52.7)^{\mathrm{e}}\end{array}$ & $\begin{array}{c}0.7 \\
(1.5)\end{array}$ & $\begin{array}{c}1.8 \\
(5.8)\end{array}$ & $\begin{array}{c}1.1 \\
(3.5)\end{array}$ & $1: 2.6: 1.6$ & 1.3 \\
\hline$\left[\left({ }^{\prime} \mathrm{bpy}\right) \mathrm{Pt}(\mathrm{Ph})\left(\mathrm{NC}_{5} \mathrm{~F}_{5}\right)\right]\left[\mathrm{BAr}_{4}\right](\mathbf{2})$ & $\begin{array}{c}8.1 \\
(19.7)\end{array}$ & $\begin{array}{c}0.6 \\
(1.1)\end{array}$ & $\begin{array}{c}1.1 \\
(2.2)\end{array}$ & $\begin{array}{c}0.7 \\
(1.3)\end{array}$ & $1: 1.8: 1.2$ & 0.7 \\
\hline$($ ('bpy) $\mathrm{Pt}(\mathrm{Ph})(\mathrm{NCMe})]\left[\mathrm{BAr}_{4}\right](\mathbf{3})$ & $\begin{array}{c}7.4 \\
(21.3)\end{array}$ & $\begin{array}{c}0.5 \\
(1.2)\end{array}$ & $\begin{array}{c}0.7 \\
(1.7)\end{array}$ & $\begin{array}{c}0.6 \\
(1.3)\end{array}$ & $1: 1.4: 1.2$ & 0.6 \\
\hline
\end{tabular}

${ }^{a}$ Catalyst $(0.025 \mathrm{~mol} \%)$ dissolved in $\mathrm{C}_{6} \mathrm{H}_{6}$ with hexamethylbenzene as internal standard at $100{ }^{\circ} \mathrm{C}$. ${ }^{b}$ Ratio of $1,2-, 1,3$-, and 1,4-diethylbenzene after $4 \mathrm{~h}$. ${ }^{c}$ Turnover frequency calculated after $4 \mathrm{~h}$ with the formation of diethylbenzenes counted as one turnover. ${ }^{d}$ Turnovers after $4 \mathrm{~h}$ as determined by GC/MS (see Experimental Section for details). ${ }^{e}$ Numbers in parentheses are turnovers after $16 \mathrm{~h}$.

ethylene was the limiting reagent, diethylbenzene production was counted as two TO.

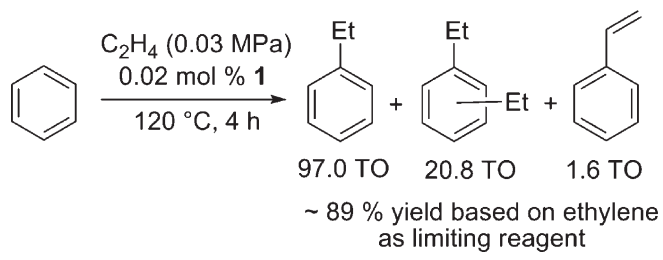

Substitution of THF with $\mathrm{NC}_{5} \mathrm{~F}_{5}$ reduces the extent of ethylbenzene production after $4 \mathrm{~h}$ by approximately $50 \%$ (Table 1). For example, using 2 at $100{ }^{\circ} \mathrm{C}$ results in $8.1 \mathrm{TO}$ of ethylbenzene and $2.4 \mathrm{TO}$ of diethylbenzenes, which gives a TOF of $0.7 \times 10^{-3} \mathrm{~s}^{-1}$. Complex 3 performed similarly to 2 with a TOF of $0.6 \times 10^{-3} \mathrm{~s}^{-1}$ and $\sim 9.2 \mathrm{TO}$ after $4 \mathrm{~h}$.

Using complex 1, we probed the influence of temperature and pressure (Table 2). With increasing temperature, the TOF of ethylbenzene production increases but catalyst decomposition is accelerated. At $90{ }^{\circ} \mathrm{C}$ under $0.1 \mathrm{MPa}$ of ethylene pressure, a solution of 1 in benzene results in a TOF of $0.4 \times 10^{-3} \mathrm{~s}^{-1}$. Increasing the temperature to $100^{\circ} \mathrm{C}$ effectively triples the rate of ethylene hydrophenylation compared to the reaction at $90{ }^{\circ} \mathrm{C}$, and at $120^{\circ} \mathrm{C}$ the rate increases by a factor of $\sim 18$ (compared to the same reaction at $90{ }^{\circ} \mathrm{C}$ ) with a TOF of $7.1 \times 10^{-3} \mathrm{~s}^{-1}$. At $90^{\circ} \mathrm{C}, 100{ }^{\circ} \mathrm{C}$ and $120^{\circ} \mathrm{C}$, increasing the ethylene pressure from 0.1 to $0.3 \mathrm{MPa}$ of ethylene results in a $\sim 63 \%$ to $75 \%$ reduction in the amount of ethylbenzene.

Although increased ethylene pressure suppresses the rate of catalysis, we postulated that catalyst longevity might be enhanced by continuous presence of ethylene. A catalytic reaction under dynamic ethylene pressure was analyzed over $\sim 70 \mathrm{~h}$. After purging the reaction vessel with ethylene and pressurizing with $\mathrm{N}_{2}(0.9 \mathrm{MPa})$, the reaction was then exposed to a constant source of ethylene $(0.9 \mathrm{MPa})$ and heated at $100^{\circ} \mathrm{C}$. A plot of TO versus time demonstrates a linear relationship with no evidence of catalyst decomposition (Figure 2).

Kinetic Studies and Isotope Effects. To determine the dependence of catalytic ethylbenzene production on the concentrations of 1 , ethylene and benzene, three sets of kinetic experiments were performed where the concentrations of two species were held constant and the concentration of the third
Table 2. Impact of Temperature and Ethylene Concentration on Catalysis Using $\left[\left({ }^{t} \mathrm{bpy}\right) \mathrm{Pt}(\mathrm{Ph})(\mathrm{THF})\right]\left[\mathrm{BAr}^{\prime}{ }_{4}\right](1){ }^{a}$

\begin{tabular}{|c|c|c|c|c|c|c|c|}
\hline $\begin{array}{l}\text { Temp } \\
\left({ }^{\circ} \mathrm{C}\right)\end{array}$ & $\begin{array}{c}\mathrm{C}_{2} \mathrm{H}_{4} \\
(\mathrm{MPa})\end{array}$ & & & & & & $\begin{array}{l}\mathrm{TOF}^{c} \\
\left(10^{-3} \mathrm{~s}^{-1}\right.\end{array}$ \\
\hline 90 & 0.1 & $\begin{array}{c}4.9^{\mathrm{d}} \\
(14.3)^{\mathrm{e}}\end{array}$ & $\begin{array}{c}0.4 \\
(0.9)\end{array}$ & $\begin{array}{c}0.6 \\
(1.4)\end{array}$ & $\begin{array}{c}0.4 \\
(0.9)\end{array}$ & 1:1.5:1.1 & 0.4 \\
\hline 90 & 0.3 & $\begin{array}{c}1.8 \\
(4.6)\end{array}$ & $\begin{array}{c}0.3 \\
(0.6)\end{array}$ & $\begin{array}{c}0.3 \\
(0.6)\end{array}$ & $\begin{array}{c}0.3 \\
(0.4)\end{array}$ & $1: 1: 1$ & 0.2 \\
\hline 100 & 0.1 & $\begin{array}{c}15.7 \\
(52.7)\end{array}$ & $\begin{array}{c}0.7 \\
(1.5)\end{array}$ & $\begin{array}{c}1.8 \\
(5.8)\end{array}$ & $\begin{array}{c}1.1 \\
(3.5)\end{array}$ & 1:2.6:1.6 & 1.3 \\
\hline 100 & 0.3 & $\begin{array}{c}4.0 \\
(8.4)\end{array}$ & $\begin{array}{c}0.3 \\
(0.7)\end{array}$ & $\begin{array}{c}0.3 \\
(0.5)\end{array}$ & $\begin{array}{c}0.3 \\
(0.6)\end{array}$ & $1: 1: 1$ & 0.3 \\
\hline 120 & 0.1 & $\begin{array}{c}89.6 \\
(107.5)\end{array}$ & $\begin{array}{c}2.7 \\
(3.5)\end{array}$ & $\begin{array}{c}6.6 \\
(8.7)\end{array}$ & $\begin{array}{c}3.7 \\
(4.7)\end{array}$ & $1: 2.5: 1.4$ & 7.1 \\
\hline 120 & 0.3 & $\begin{array}{c}23.4 \\
(71.8)\end{array}$ & $\begin{array}{c}1.4 \\
(3.8)\end{array}$ & $\begin{array}{c}2.6 \\
(8.2)\end{array}$ & $\begin{array}{c}1.7 \\
(4.6)\end{array}$ & 1:1.9:1.2 & 2.0 \\
\hline
\end{tabular}

${ }^{a}$ Catalyst $(0.025 \mathrm{~mol} \%)$ dissolved in $\mathrm{C}_{6} \mathrm{H}_{6}$ with hexamethylbenzene as an internal standard at $100{ }^{\circ} \mathrm{C}$. ${ }^{b}$ Ratio of 1,2 -, 1,3-, and 1,4-diethylbenzene after $4 \mathrm{~h}$. ${ }^{c}$ Turnover frequency calculated after $4 \mathrm{~h}$; formation of diethylbenzenes counted as one turnover. ${ }^{d}$ Turnovers after $4 \mathrm{~h}$ as determined by GC/MS. ${ }^{e}$ Numbers in parentheses are turnovers after $16 \mathrm{~h}$.

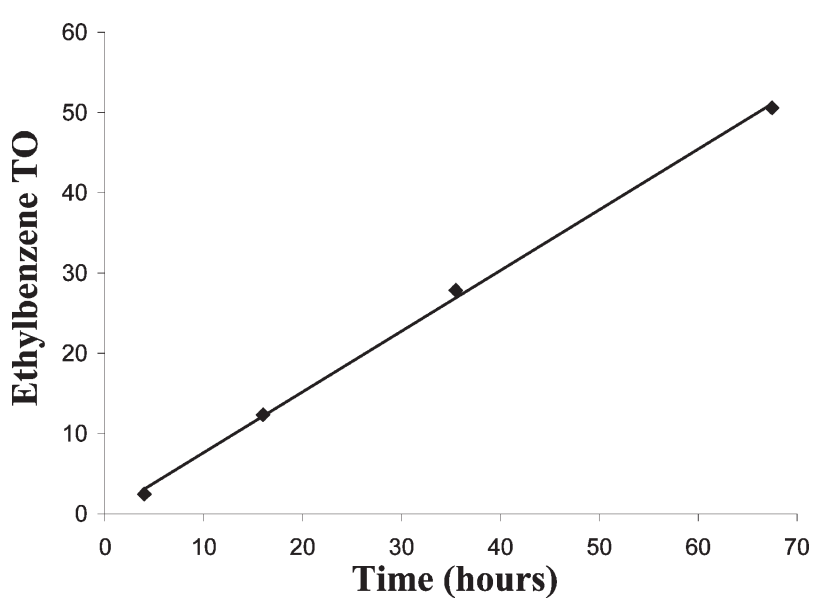

Figure 2. Catalysis using complex $\mathbf{1}$, benzene, and dynamic ethylene pressure maintained at $0.9 \mathrm{MPa}\left(100{ }^{\circ} \mathrm{C} ; R^{2}=0.99\right)$.

species was varied. We used conditions where the rate of catalysis was monitored through $\leq 5$ TOs since data from early in the reaction is not influenced by catalyst decomposition. To show the dependence of rate on the concentration of each substrate, we plotted the concentration of ethylbenzene, at a specified time, versus the concentration of 1 , ethylene or benzene (Figures 3-5). The production of ethylbenzene displays a first-order dependence on the concentration of 1 (Figure 3). Catalytic reactions performed in $\mathrm{NC}_{5} \mathrm{~F}_{5}$ with varying concentrations of benzene $(0.1$ to $2.7 \mathrm{M})$ display saturation kinetics (Figure 4). Catalysis was studied over an ethylene concentration range of 0.04 to $0.13 \mathrm{M}$, and catalyst activity decreases with increasing ethylene concentration, and saturation kinetics are observed at higher ethylene concentrations (Figure 5). Similar effects of increased olefin concentration on rate of catalysis have been observed with $\mathrm{Ru}(\mathrm{II})$ systems. ${ }^{18}$ Comparative rates 


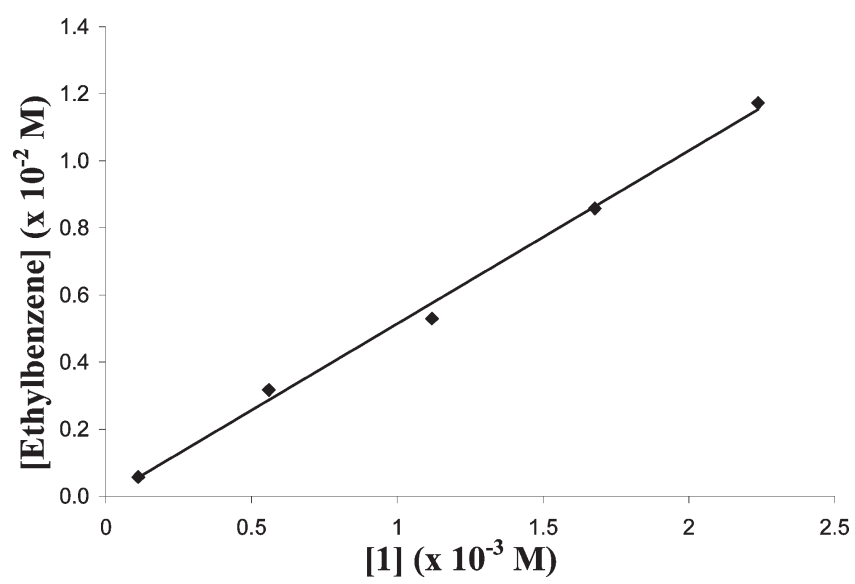

Figure 3. Plot of [ethylbenzene] (M) after $30 \mathrm{~min}$ as a function of [1] (M) at $100{ }^{\circ} \mathrm{C}$ with $0.1 \mathrm{MPa}$ of ethylene in neat benzene $\left(\mathrm{R}^{2}=0.99\right)$.

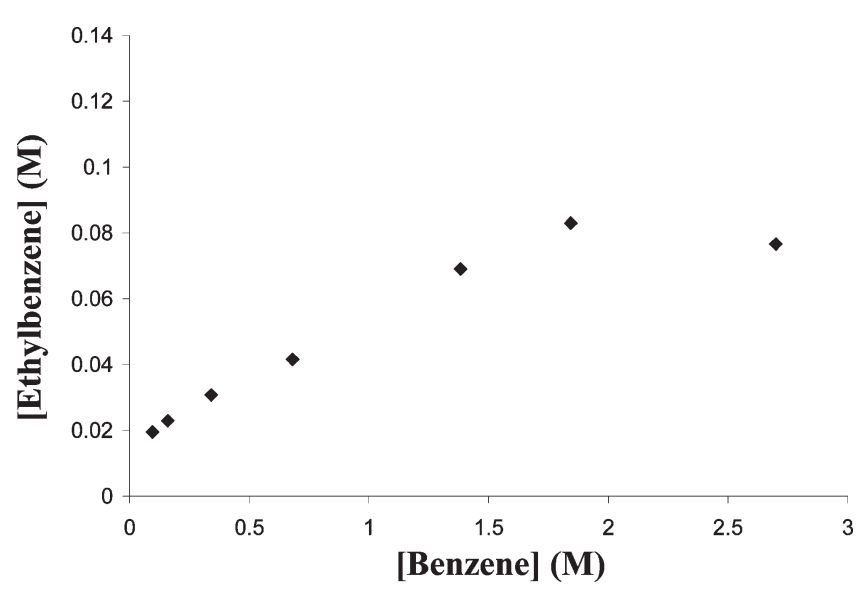

Figure 4. Plot of [ethylbenzene] (M) after $2 \mathrm{~h}$ as a function of [benzene] (M) at $100{ }^{\circ} \mathrm{C}$ in perfluoropyridine with [ethylene] = $0.16(5) \mathrm{M}$ and $[1]=0.03 \mathrm{M}$.

of ethylene hydrophenylation with $\mathrm{C}_{6} \mathrm{H}_{6}$ and $\mathrm{C}_{6} \mathrm{D}_{6}$ were used to determine the kinetic isotope effect (KIE) for catalytic reactions. In separate experiments that incorporated either $\mathrm{C}_{6} \mathrm{H}_{6}$ or $\mathrm{C}_{6} \mathrm{D}_{6}$, using the ratio of total TO after $4 \mathrm{~h}$ of reaction (taken from multiple experiments under identical conditions) a KIE for the catalytic reaction of 1.8(4) was determined.

To study stoichiometric benzene $\mathrm{C}-\mathrm{H}$ activation by $\left[\left({ }^{t} \mathrm{bpy}\right) \mathrm{Pt}(\mathrm{R})\right]^{+}$systems, we used the reaction of $\left[\left({ }^{t} \mathrm{bpy}\right) \mathrm{Pt}-\right.$ $\left.\left(\mathrm{Ph}-d_{n}\right)(\mathrm{THF})\right]^{+}\left[n=5\left(\mathbf{1}-\boldsymbol{d}_{5}\right)\right.$ or $\left.0(\mathbf{1})\right]$ with excess $\mathrm{C}_{6} \mathrm{H}_{6}$ or $\mathrm{C}_{6} \mathrm{D}_{6}$. The reaction of $1-d_{5}$ and $\mathrm{C}_{6} \mathrm{H}_{6}$ at $21{ }^{\circ} \mathrm{C}$ in $\mathrm{CD}_{2} \mathrm{Cl}_{2}$ leads to the formation of 1 and $\mathrm{C}_{6} \mathrm{D}_{5} \mathrm{H}$ with an observed pseudo-firstorder rate constant of 7.1(4) $\times 10^{-5} \mathrm{~s}^{-1}$. A pseudo-first-order rate constant of 5.0(3) $\times 10^{-5} \mathrm{~s}^{-1}$ is observed for the same reaction between $\mathbf{1}$ and $\mathrm{C}_{6} \mathrm{D}_{6}$ to form $\mathbf{1}-\boldsymbol{d}_{5}$ and $\mathrm{C}_{6} \mathrm{H}_{5} \mathrm{D}$. The activation of a benzene $\mathrm{C}-\mathrm{H} / \mathrm{D}$ bond results in a KIE of 1.4(1) (Scheme 1), which is statistically indistinguishable from the catalytic KIE, and the magnitude of the KIE is similar to that previously observed for arene and aliphatic $\mathrm{C}-\mathrm{H}$ activation by $\mathrm{Pt}(\mathrm{II})$ systems. ${ }^{32,34,46,47}$ The impact of the weakly coordinating Lewis base THF on the rate of benzene $\mathrm{C}-\mathrm{D}$ activation by 1 was investigated. The reaction rate decreases with increasing THF concentration (Figure 6). At $30^{\circ} \mathrm{C}$ in $\mathrm{CD}_{2} \mathrm{Cl}_{2}$, the conversion of 1 to $1-d_{5}$ with $0.18 \mathrm{M} \mathrm{C}_{6} \mathrm{D}_{6}$ proceeds with an observed rate of

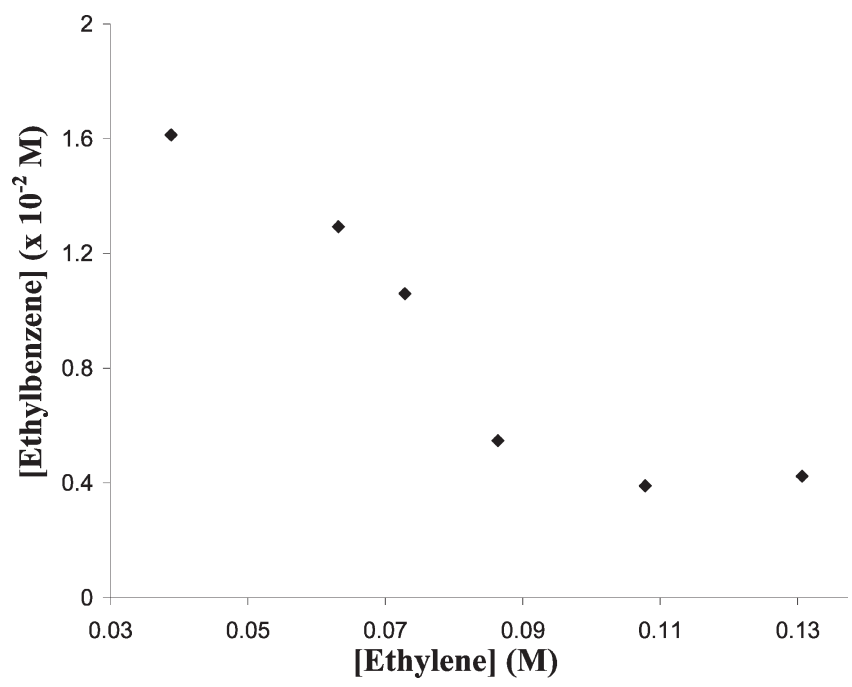

Figure 5. Plot of [ethylbenzene] (M) after $2 \mathrm{~h}$ as a function of [ethylene] (M) at $100{ }^{\circ} \mathrm{C}$ in $\mathrm{C}_{6} \mathrm{D}_{6}$ and $[\mathbf{1}]=0.028 \mathrm{M}$.

4.6(4) $\times 10^{-5} \mathrm{~s}^{-1}$. At low concentrations of $\mathrm{C}_{6} \mathrm{D}_{6}$, a first-order dependence on concentration of $\mathrm{C}_{6} \mathrm{D}_{6}$ is observed, and as the concentration of $\mathrm{C}_{6} \mathrm{D}_{6}$ is increased, saturation conditions are reached (Figure 7).

Two pathways for stoichiometric benzene $\mathrm{C}-\mathrm{H}$ activation by $\mathbf{1}$ are shown in Scheme 2, which are distinguished by associative versus dissociative pathways for benzene/THF exchange. Rate laws were derived assuming that benzene $\mathrm{C}-\mathrm{H} / \mathrm{D}$ coordination is the rate-limiting step and by applying the steady-state approximation (reaction intermediates are not observed). The small primary KIE of 1.4(1) is consistent with similarly small KIEs $\left(k_{\mathrm{H}} / k_{\mathrm{D}} \sim 1.1-1.4\right)$ for $\mathrm{C}-\mathrm{H} / \mathrm{D}$ activation by $\mathrm{d}^{8}$ metal centers, which have been interpreted as rate-determining $\mathrm{C}-\mathrm{H}$ coordination. ${ }^{46,48,49}$ Rate-limiting C-H/D activation by d $\mathrm{d}^{8}$ metals have been reported to exhibit KIEs $\geq 2.5 .{ }^{50,51}$ Both pathways predict an inverse dependence on the concentration of THF; however, only the rate law for the dissociative pathway is consistent with the observation of saturation kinetics for variation of benzene concentration. Thus, we suggest that the dissociative pathway with rate-determining $\mathrm{C}-\mathrm{H}$ coordination is most likely. Studies of $\mathrm{C}-\mathrm{H}$ activation by other cationic $\mathrm{Pt}(\mathrm{II})$ systems with hydrocarbyl ligands suggest similar pathways that likely involve threecoordinate Pt complexes. ${ }^{41}$ It should be noted that rapid preequilibrium conditions would be consistent with either pathway. ${ }^{52}$ The KIE $\left(\mathrm{C}_{6} \mathrm{H}_{6}\right.$ vs $\left.\mathrm{C}_{6} \mathrm{D}_{6}\right)$ for the catalytic cycle is larger $\left[k_{\mathrm{H}} / k_{\mathrm{D}}=1.8(4)\right]$, but the deviation is also larger. Thus, the $\mathrm{KIE}$ for the catalytic cycle is consistent with either rate-limiting $\mathrm{C}-\mathrm{H}$ coordination or $\mathrm{C}-\mathrm{H}$ activation. A change of the ratedetermining step for stoichiometric benzene $\mathrm{C}-\mathrm{H}$ activation versus the catalytic cycle might be explained by a similar magnitude for the two steps (i.e., $\mathrm{C}-\mathrm{H}$ coordination and $\mathrm{C}-\mathrm{H}$ bond breaking) and a change in relative barrier height for $\mathrm{C}-\mathrm{H}$ activation by a $\mathrm{Pt}-$ phenyl versus $\mathrm{Pt}-\mathrm{CH}_{2} \mathrm{CH}_{2} \mathrm{Ph}$.

Computational Study of Benzene $\mathrm{C}-\mathrm{H}$ Activation by $\left[\left({ }^{t} \text { bpy }\right) \mathrm{Pt}\left(\mathrm{CH}_{2} \mathrm{CH}_{2} \mathrm{Ph}\right)\right]^{+}$. The mechanisms by which $\mathrm{Pt}(\mathrm{II})$ systems activate the $\mathrm{C}-\mathrm{H}$ bonds of hydrocarbons have been studied extensively, ${ }^{41,53-55}$ and the two mechanisms most commonly invoked are electrophilic substitution and oxidative addition (Scheme 3). ${ }^{32,41,46,56-59}$ In addition, recent studies suggest that exchange of phenyl groups in $\left[(\mathrm{N}-\mathrm{N}) \mathrm{Pt}(\mathrm{Ph})\left(\mathrm{C}_{6} \mathrm{H}_{6}\right)\right]^{+}$ 
Scheme 1. Rates of Degenerate Benzene C-H/D Activation by 1 and $1-d_{5}$ in $\mathrm{CD}_{2} \mathrm{Cl}_{2}\left([\mathrm{Pt}]=0.03 \mathrm{M}\right.$, $[$ benzene $\left.]=0.5 \mathrm{M}, 21^{\circ} \mathrm{C}\right)$

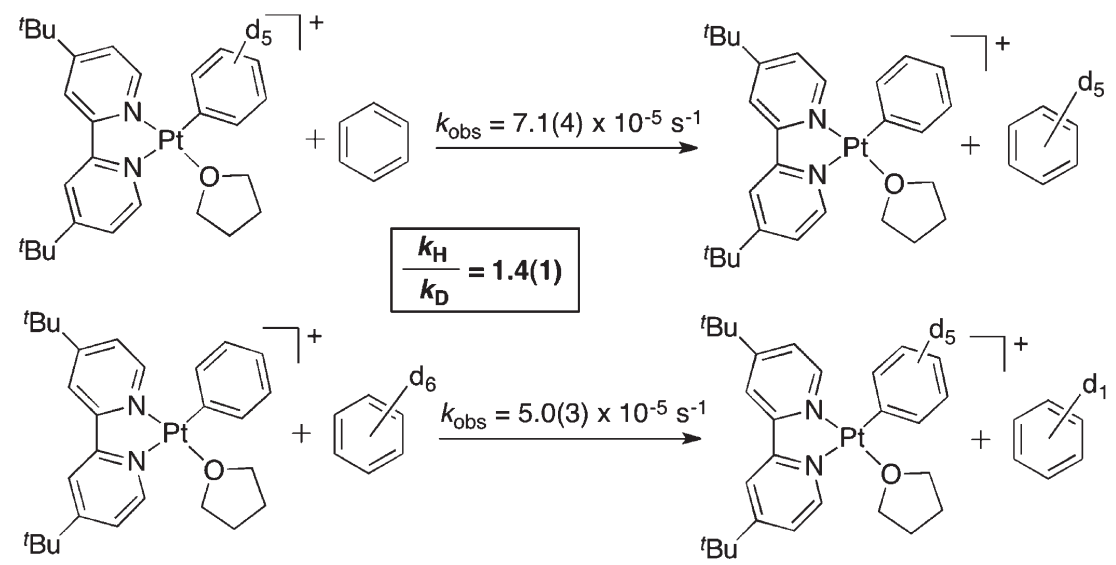

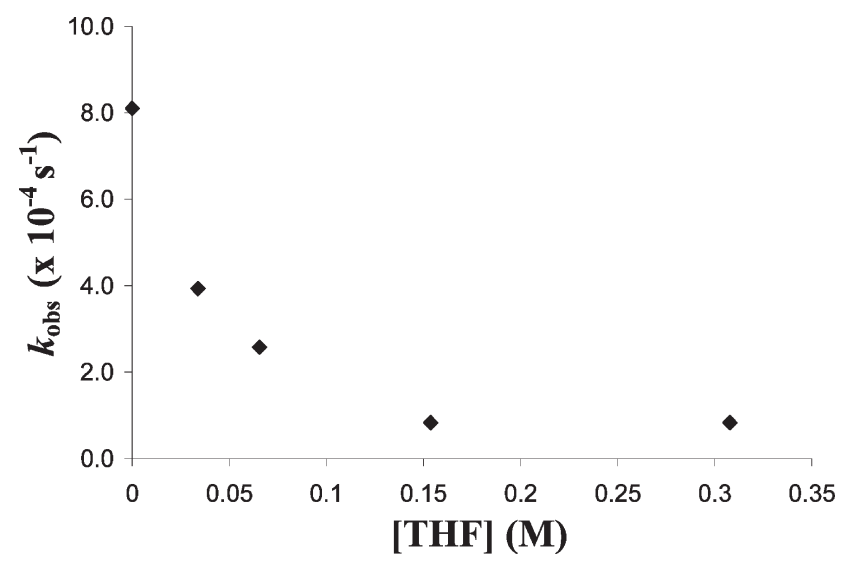

Figure 6. Observed rate of benzene $\mathrm{C}-\mathrm{D}$ activation by 1 as a function of THF concentration in $\mathrm{CD}_{3} \mathrm{NO}_{2}\left([1]=0.03 \mathrm{M},\left[\mathrm{C}_{6} \mathrm{D}_{6}\right]=0.5 \mathrm{M}, 45^{\circ} \mathrm{C}\right)$.

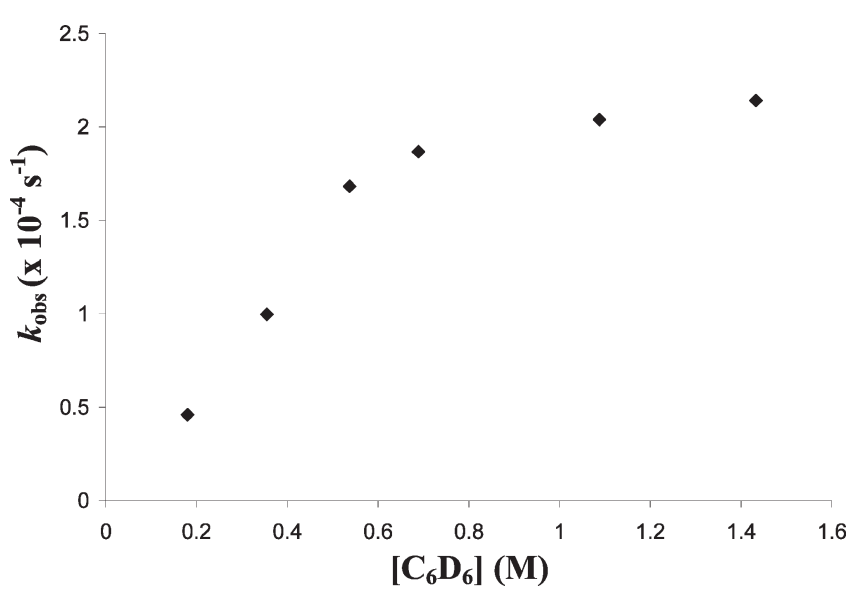

Figure 7. Observed rate of benzene $\mathrm{C}-\mathrm{D}$ activation by 1 as a function of benzene concentration in $\mathrm{CD}_{2} \mathrm{Cl}_{2} .\left([1]=0.03 \mathrm{M}, 30^{\circ} \mathrm{C}\right)$.

$\left(\mathrm{N}-\mathrm{N}=\mathrm{ArN}=\mathrm{CMe}-\mathrm{CMe}=\mathrm{NAr}, \mathrm{Ar}=2,6-\mathrm{Me}_{2} \mathrm{C}_{6} \mathrm{H}_{3}\right)$ occurs by a $\sigma$-bond metathesis pathway with a calculated activation energy $\sim 5.0 \mathrm{kcal} / \mathrm{mol}$ lower than that calculated for oxidative addition. ${ }^{60}$ The calculated transition state is similar to that proposed for $\sigma$-bond metathesis-type transition states in which the metal appears to interact with the activated hydrogen, which have been coined " $\sigma$-complex assisted metathesis" ( $\sigma$-CAM) or oxidative hydrogen migration. ${ }^{27,61-67}$

In our computational modeling, we considered aromatic $\mathrm{C}-\mathrm{H}$ activation by $\left[\left({ }^{t} \text { bpy }\right) \mathrm{Pt}\left(\mathrm{CH}_{2} \mathrm{CH}_{2} \mathrm{Ph}\right)\right]^{+}$, which is likely the catalytically relevant species, via $\sigma$-bond metathesis and oxidative addition/reductive elimination pathways. For all simulations, the parent 2,2'-bipyridine (bpy) was used in place of ${ }^{t}$ bpy. A two-step oxidative addition/reductive elimination pathway was calculated to be favored over a one-step $\sigma$-bond metathesis mechanism by $2.3 \mathrm{kcal} / \mathrm{mol}$ (Scheme 4). The core geometries of the three transition states (i.e., transition states for $\sigma$-bond metathesis, oxidative addition and reductive elimination), plus the fivecoordinate hydride intermediate, are shown in Figure 8. All of these species are calculated to have short $\mathrm{Pt}-\mathrm{H}$ distances, with the longest ( $1.68 \AA$ ) being the kite-shaped $\sigma$-bond metathesis transition state, for which the $\mathrm{H}$ atom is transferred in the equatorial plane from the aryl ring to the alkyl fragment. This distance is similar to bona fide bond distances of isolated $\mathrm{Pt}$-hydride complexes, which are in the range of $1.63-1.68 \AA^{68,69}$

Ethylene Insertion. In contrast to $\mathrm{Ni}$ and $\mathrm{Pd}$ systems, $\mathrm{Pt}$ complexes have not been reported to be efficient catalysts for olefin polymerization, ${ }^{70}$ and five-coordinate $\mathrm{Pt}(\mathrm{II})$ complexes with coordinated olefin have been characterized. ${ }^{71-76}$ Studies of olefin insertion into $\mathrm{Pt}(\mathrm{II})$ hydrocarbyl bonds suggest that insertion of unactivated olefins into $\mathrm{Pt}-\mathrm{R}$ bonds is feasible for cationic systems when $\mathrm{R}=\operatorname{aryl} ;^{74,75,77}$ however, insertions appear to have more substantial barriers when $\mathrm{R}=$ alkyl $^{74,75,77}$ and for overall charge neutral systems. ${ }^{72,76}$ Ruffo et al. have reported the insertion of electron-deficient olefins into the $\mathrm{Pt}(\mathrm{II})-\mathrm{Me}$ bond of a cationic system. ${ }^{78}$ In addition, Templeton and co-workers have reported ethylene insertion into a $\mathrm{Pt}-$ phenyl bond at $80^{\circ} \mathrm{C}$, after which intramolecular $\mathrm{C}-\mathrm{H}$ activation of ethylbenzene occurs to form a stable $\mathrm{Pt}(\mathrm{IV})$ ortho-metalated phenethyl complex. ${ }^{42}$

The reaction of $\mathbf{1}$ or $\mathbf{2}$ with ethylene at room temperature in dichloromethane produces $\left[\left({ }^{t} \mathrm{bpy}\right) \mathrm{Pt}\left(\mathrm{CH}_{2} \mathrm{CH}_{2} \mathrm{Ph}\right)\left(\eta^{2}-\mathrm{C}_{2} \mathrm{H}_{4}\right)\right]$ $\left[\mathrm{BAr}_{4}^{\prime}\right.$ ] (4) in 97\% isolated yield for complex 1 (eq 4). In the ${ }^{1} \mathrm{H}$ NMR spectrum $\left(\mathrm{CD}_{2} \mathrm{Cl}_{2}\right.$, room temperature) of 4 , a single resonance is observed at $4.14 \mathrm{ppm}$ for the coordinated ethylene, which indicates a fluxional process that is rapid on the NMR time scale. A suitable crystal of $\mathbf{4}$ was grown for an X-ray diffraction study (Figure 9). The $\mathrm{Pt}-\mathrm{N} 1$ bond trans to the $\eta^{2}$-ethylene is shortened by $0.06 \AA$ A relative to the $\mathrm{Pt}-\mathrm{N} 2$ bond trans to the alkyl ligand, presumably due to the stronger trans influence of the alkyl 
Scheme 2. Two Possible Mechanisms for Stoichiometric Benzene C-H Activation by $1\left([\mathrm{Pt}]=\left[\left({ }^{t} \mathrm{bpy}\right) \mathrm{Pt}\right]\right)$

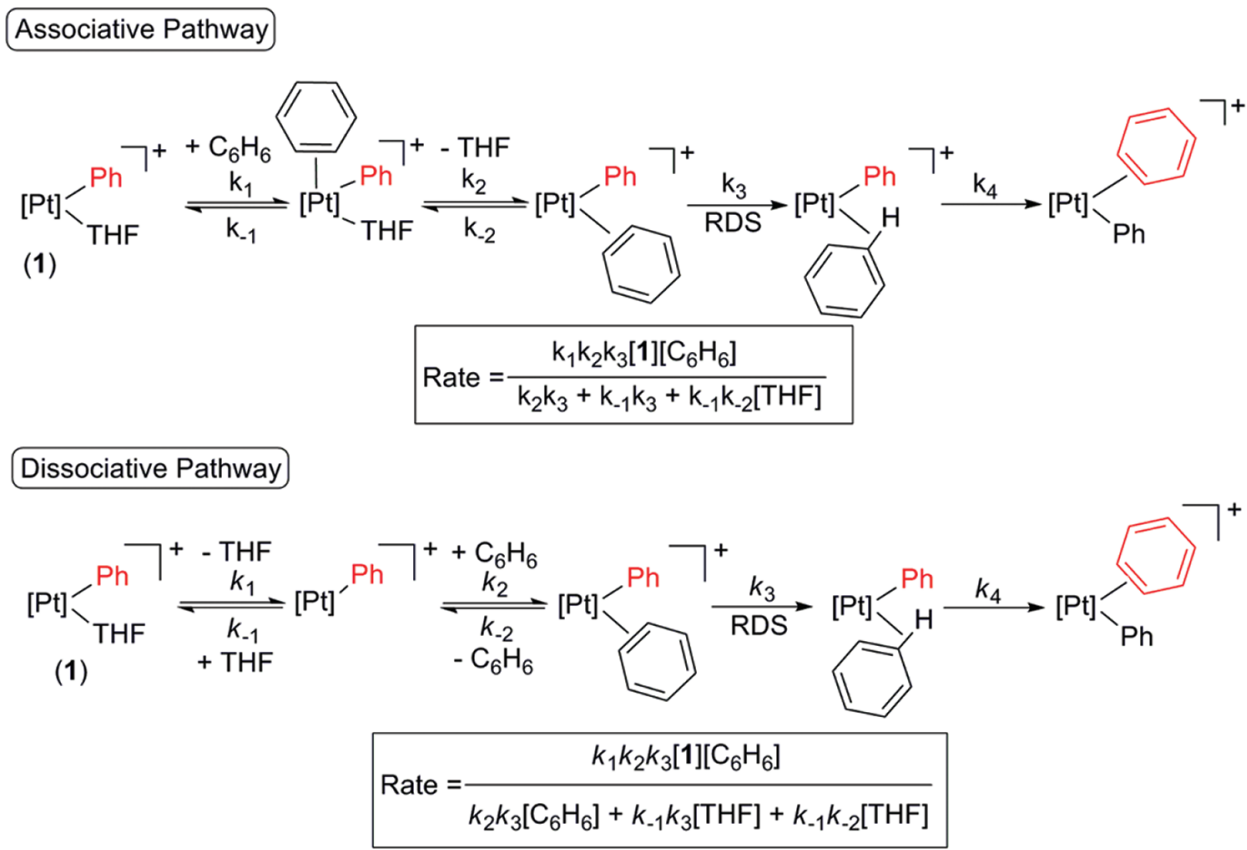

Scheme 3. Pt(II)-Mediated C-H Activation via Electrophilic Substitution, Oxidative Addition or $\sigma$-Bond Metathesis

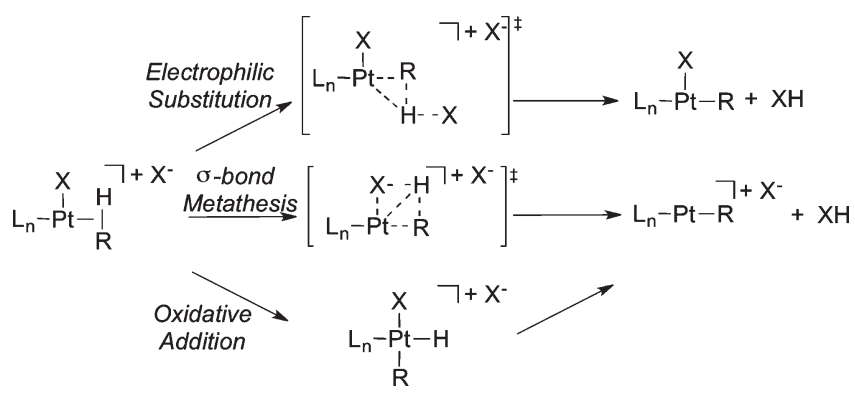

ligand. ${ }^{45,79}$ The phenyl ring is oriented over the cis-pyridyl ring, and the $\mathrm{Pt}-\mathrm{C} 44$ bond is distorted by $\sim 11.7^{\circ}$ out of the square plane. The $\mathrm{C}-\mathrm{C}$ bond of ethylene is oriented perpendicular to the coordination square plane and only slightly elongated $[1.393(6) \AA]$ relative to uncoordinated ethylene $(1.339 \AA),{ }^{80}$ which is more representative of a $\mathrm{C}=\mathrm{C}$ moiety than a metallacyclopropane, similar to that observed for other $\mathrm{Pt}(\mathrm{II})-$ olefin complexes. ${ }^{45,79}$

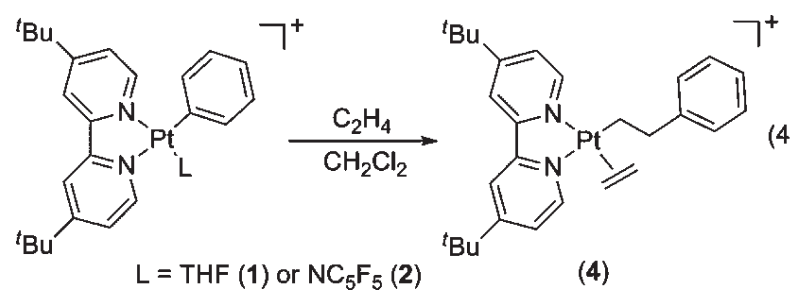

Monitoring the rate of conversion of $1(0.03 \mathrm{M})$ and ethylene $(0.1 \mathrm{M})$ to 4 in $\mathrm{CD}_{2} \mathrm{Cl}_{2}$ under pseudo-first-order conditions at $23{ }^{\circ} \mathrm{C}$ reveals a $k_{\mathrm{obs}}=1.07(2) \times 10^{-3} \mathrm{~s}^{-1}$ (Figure 10). Thus, complex 1 is capable of ethylene coordination and insertion at
Scheme 4. Calculated Reaction Coordinate ( $\Delta G$ in THF, $\mathrm{kcal} / \mathrm{mol}$ ) Comparing a Two-Step (Oxidative Addition/ Reductive Elimination) Pathway via a $\mathrm{Pt}(\mathrm{IV})$ - Hydride with a One-Step ( $\sigma$-Bond metathesis, in red) Pathway for Benzene $\mathrm{C}-\mathrm{H}$ Activation from $\left[(\mathrm{bpy}) \mathrm{Pt}\left(\mathrm{CH}_{2} \mathrm{CH}_{2} \mathrm{Ph}\right)\left(\eta^{2}-\mathrm{C}_{6} \mathrm{H}_{6}\right)\right]^{+}$

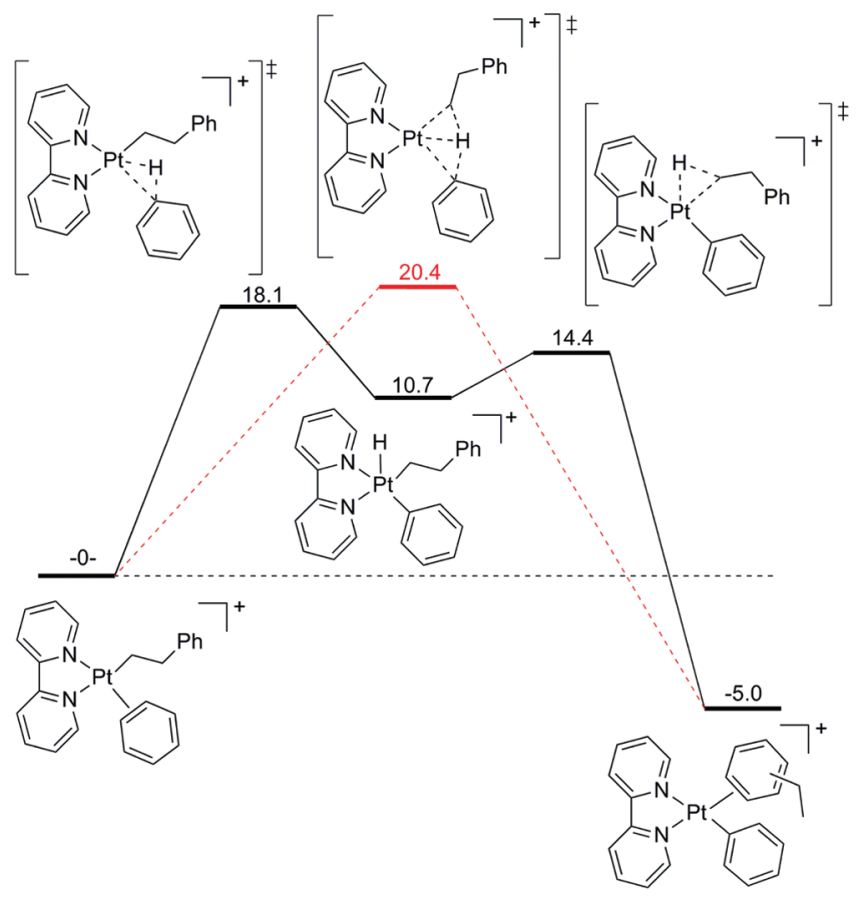

room temperature, and the reaction rate at this low temperature implicates that the process is a viable step in the catalytic ethylene hydrophenylation transformation at $100{ }^{\circ} \mathrm{C}$. The dependence of the rate of conversion of 1 and ethylene to 4 on ethylene concentration $(0.1$ to $1.5 \mathrm{M})$ was probed. At low concentrations 

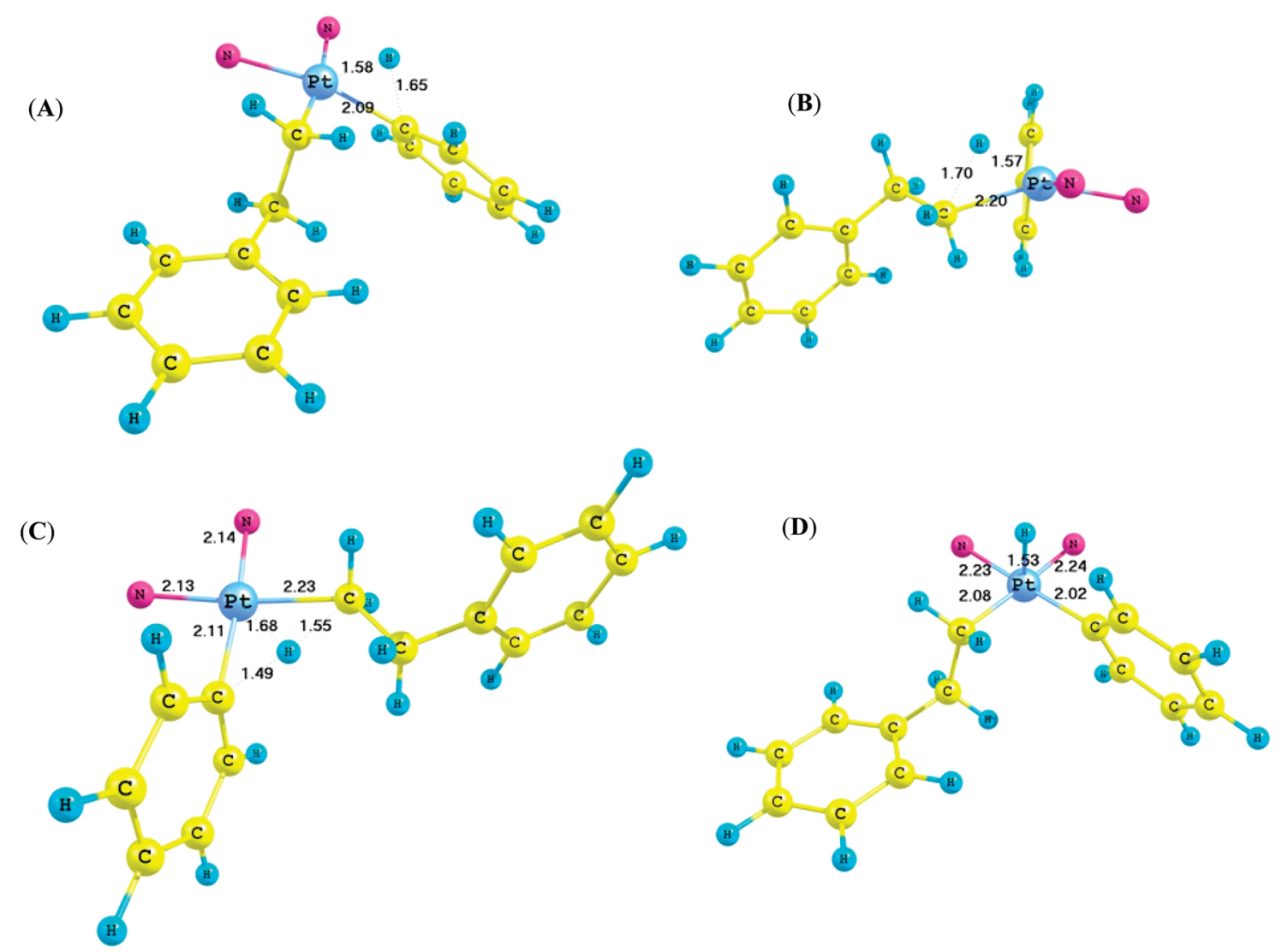

Figure 8. Calculated structures of pertinent stationary points (see Scheme 4) from $\left[(\text { bpy }) \mathrm{Pt}\left(\mathrm{CH}_{2} \mathrm{CH}_{2} \mathrm{Ph}\right)\left(\eta^{2}-C, C-\mathrm{C}_{6} \mathrm{H}_{6}\right)\right]^{+}$. Shown are the transition states for benzene $\mathrm{C}-\mathrm{H}$ oxidative addition $(\mathrm{A})$, ethylbenzene reductive elimination $(\mathrm{B})$, and $\sigma$-bond metathesis $(\mathrm{C})$ in addition to a five-coordinate, $\mathrm{Pt}$-hydride intermediate (D) that is the successor to the oxidative addition transition state and the precursor to the reductive elimination transition state. Only the two nitrogens of the bipyridyl ligand are shown to increase the clarity of the Pt core.

of ethylene, the rate increases approximately linearly with increasing ethylene concentration, and at higher ethylene concentrations saturation is observed (Figure 11). The addition of 2, 5 , and 10 equiv ( 0.06 to $0.3 \mathrm{M}$ ) of THF- $d_{8}$ (relative to 1 ) had negligible impact on the rate of insertion (Figure 12).

Two pathways were considered for ethylene coordination and insertion, an associative and a dissociative process. Scheme 5 shows the two reaction pathways and the corresponding rate laws, which were derived using the steady-state approximation. Both rate laws predict saturation kinetics as a function of ethylene concentration; however, the independence of the rate on the concentration of THF is most consistent with the associative mechanism (Scheme 5). At high concentrations of ethylene, the rate law for the associative process becomes Rate $=k_{2}[\mathbf{1}]$. Using the first-order rate constant for the formation of 4 at $1.5 \mathrm{M}$ ethylene of $2.1(1) \times 10^{-3} \mathrm{~s}^{-1}\left(23^{\circ} \mathrm{C}\right)$ corresponds to a $\Delta G^{\ddagger}=$ 21.0 (1) $\mathrm{kcal} / \mathrm{mol}$, which is similar to the $\Delta G^{\mp}$ of $19.2 \mathrm{kcal} / \mathrm{mol}$ $\left(64{ }^{\circ} \mathrm{C}\right)$ determined by Brookhart, Templeton, et al. for ethylene insertion into the $\mathrm{Pt}-\mathrm{H}$ bond of $[(\mathrm{N}-\mathrm{N}) \mathrm{Pt}(\mathrm{H})$ (ethylene $)]^{+}\left[\mathrm{N}-\mathrm{N}=\left(2,6-\mathrm{Me}_{2} \mathrm{C}_{6} \mathrm{H}_{3}\right) \mathrm{N}=\mathrm{C}(\mathrm{An})-\mathrm{C}(\mathrm{An})=\right.$ $\mathrm{N}\left(2,6-\mathrm{Me}_{2} \mathrm{C}_{6} \mathrm{H}_{3}\right) ; \mathrm{An}=1,8$-naphthalenediyl]. ${ }^{45}$

Simulations were used to compare associative and dissociative mechanisms for ethylene insertion starting from $[(\mathrm{bpy}) \mathrm{Pt}(\mathrm{Ph})$ $(\mathrm{THF})]^{+}\left(\mathbf{1}^{\prime}\right)$ (Scheme 6). The associative pathway has a calculated $\Delta G^{\ddagger}$ of $19.0 \mathrm{kcal} / \mathrm{mol}$, which is close to the experimentally determined activation barrier of $21.0(1) \mathrm{kcal} / \mathrm{mol}\left(23.0^{\circ} \mathrm{C}\right)$. After evaluation of multiple coordination isomers for the associative pathway, the lowest energy isomer of the ethylene adduct, $\left[(\text { bpy }) \mathrm{Pt}(\mathrm{Ph})(\mathrm{THF})\left(\eta^{2}-\mathrm{C}_{2} \mathrm{H}_{4}\right)\right]^{+}$, has the ethylene bound to $\mathrm{Pt}$ with THF weakly associated, viz. [(bpy) $\mathrm{Pt}(\mathrm{Ph})$ $\left.\left(\eta^{2}-\mathrm{C}_{2} \mathrm{H}_{4}\right)\right]^{+} \cdot(\mathrm{THF})$. From $\left[(\text { bpy }) \mathrm{Pt}(\mathrm{Ph})\left(\eta^{2}-\mathrm{C}_{2} \mathrm{H}_{4}\right)\right]^{+} \cdot(\mathrm{THF})$, the most stable calculated transition state for ethylene insertion has THF in the outer coordination sphere and $19.0 \mathrm{kcal} / \mathrm{mol}$ relative to $\left[(\mathrm{bpy}) \mathrm{Pt}(\mathrm{Ph})\left(\eta^{2}-\mathrm{C}_{2} \mathrm{H}_{4}\right)\right]^{+} \cdot(\mathrm{THF})$ (Scheme 6). Searches for transition states for $\mathrm{C}=\mathrm{C}$ insertion into the $\mathrm{Pt}-\mathrm{Ph}$ bond of $\left[(\mathrm{bpy}) \mathrm{Pt}(\mathrm{Ph})\left(\eta^{2}-\mathrm{C}_{2} \mathrm{H}_{4}\right)(\mathrm{THF})\right]^{+}$with $\mathrm{THF}$ in the inner coordination sphere resulted in a high-energy transition state with dissociation of one of the bpy arms. The dissociative displacement of THF with ethylene is calculated to be exergonic by $12.5 \mathrm{kcal} / \mathrm{mol}$ and features a free energy barrier of $19.7 \mathrm{kcal} / \mathrm{mol}$ for ethylene insertion into the $\mathrm{Pt}$ - phenyl bond from $7^{\prime}$ to $(7-8)^{\prime}$. Thus, the overall calculated $\Delta G^{\neq}$for the dissociative pathway is $0.7 \mathrm{kcal} / \mathrm{mol}$ greater than that for the associative pathway, which is insufficient to differentiate the two pathways solely on the basis of the calculations; however, the combination of kinetic experiments and computational analysis suggests a process that has associative character in what might be best considered as an interchange associative pathway. ${ }^{81}$

Proposed Mechanism for the Catalytic Cycle. Metalmediated olefin hydroarylation can proceed by a Friedel-Crafts pathway or by metal-mediated olefin insertion into a metalphenyl bond followed by aromatic $\mathrm{C}-\mathrm{H}$ activation. As anticipated for relatively electron-rich octahedral $\mathrm{d}^{6}$ systems, results from studies of $\mathrm{Ru}(\mathrm{II})$ and $\mathrm{Ir}(\mathrm{III})$ catalysts are consistent with a 


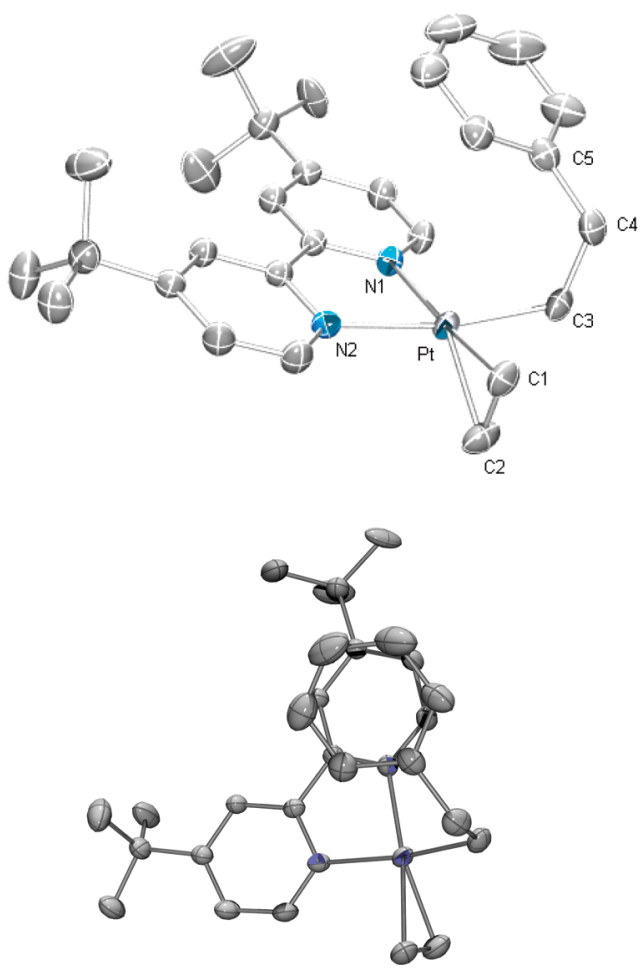

Figure 9. ORTEP of $\left[\left({ }^{t} \mathrm{bpy}\right) \mathrm{Pt}\left(\mathrm{CH}_{2} \mathrm{CH}_{2} \mathrm{Ph}\right)\left(\eta^{2}-\mathrm{C}_{2} \mathrm{H}_{4}\right)\right]\left[\mathrm{BAr}^{\prime}{ }_{4}\right]$ (4) (50\% probability; $\mathrm{H}$ atoms and $\mathrm{BAr}^{\prime}{ }_{4}$ anion omitted for clarity) Selected bond lengths ( $\AA$ ): Pt-N1 2.069(4), Pt-N2 2.127(4), Pt-C3 2.052(5), $\mathrm{Pt}-\mathrm{C} 12.144(5), \mathrm{Pt}-\mathrm{C} 2$ 2.118(4), C1-C2 1.393(6). Selected bond angles (deg): $\mathrm{N} 1-\mathrm{Pt}-\mathrm{N} 2$ 78.4(1), $\mathrm{Pt}-\mathrm{C} 3-\mathrm{C} 4111.3(3), \mathrm{C} 3-\mathrm{C} 4-\mathrm{C} 5$ 115.5(3). View on the bottom shows stacking of phenyl group of phenethyl ligand and pyridyl of tbpy ligand.

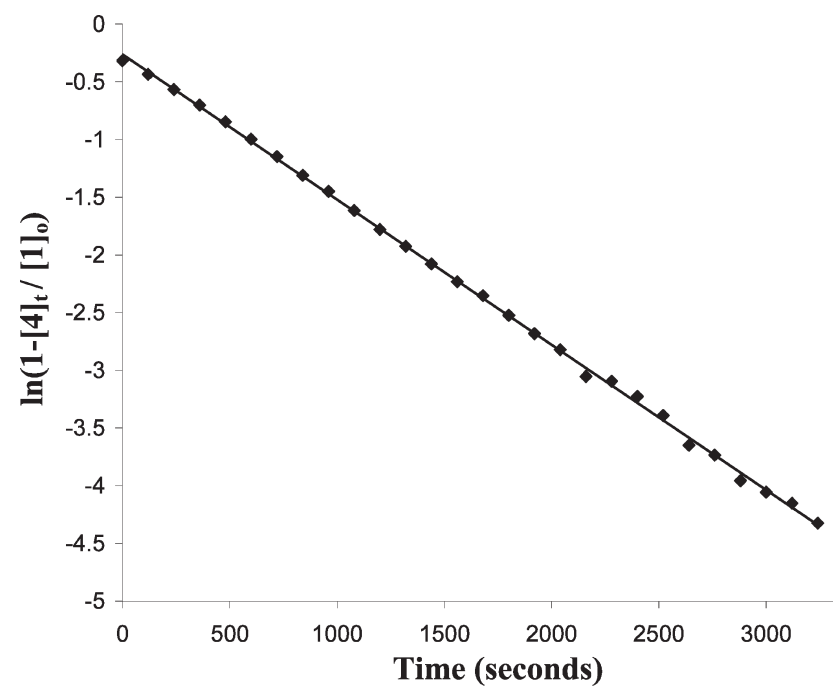

Figure 10. Representative kinetic plot for the conversion of 1 to 4 $\left([\mathbf{1}]=0.031 \mathrm{M},\left[\mathrm{C}_{2} \mathrm{H}_{4}\right]=0.1 \mathrm{M}, 23{ }^{\circ} \mathrm{C}\right)$.

non-Friedel-Crafts pathway. ${ }^{18-20,23,25,27,28}$ In contrast, reaction pathways are likely to be less predictable with later transition metals, such as $\mathrm{Pt}(\mathrm{II})$, that, in general, have enhanced electrophilicity. For example, Vitagliano et al. have reported that $\mathrm{Pt}-$ ethylene complexes are susceptible to nucleophilic addition by electron-rich aromatic compounds that are activated by

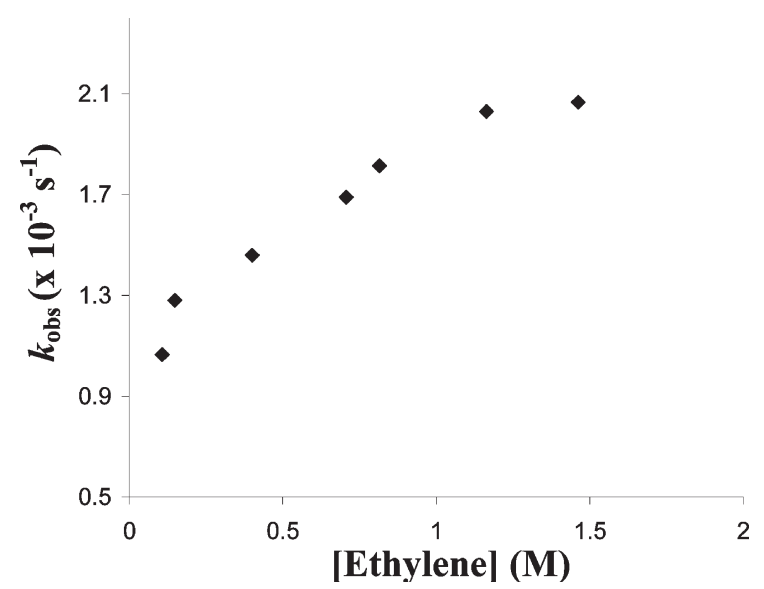

Figure 11. Plot of $k_{\mathrm{obs}}$ for the conversion of $\mathbf{1}$ and ethylene to 4 as a function of ethylene concentration $(\mathrm{M})\left([1]=0.03 \mathrm{M}, 23.0^{\circ} \mathrm{C}\right)$.

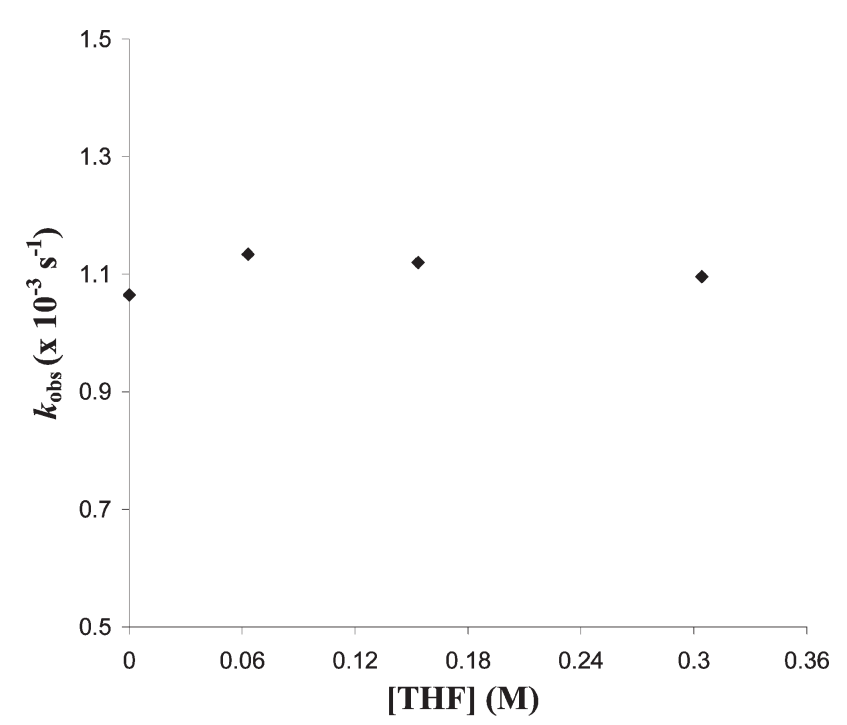

Figure 12. Plot of $k_{\mathrm{obs}}$ for the conversion of 1 and ethylene to 4 as a function of THF concentration $(\mathrm{M})\left([\mathbf{1}]=0.03 \mathrm{M},\left[\mathrm{C}_{2} \mathrm{H}_{4}\right]=\right.$ $\left.0.11(2) \mathrm{M}, 23.0^{\circ} \mathrm{C}\right)$.

methoxy substituents. ${ }^{82}$ Evidence that the hydroarylation of cyclohexene using $\mathrm{L}_{2} \mathrm{Pt}(\mathrm{OTf})_{2}\left(\mathrm{~L}_{2}=1,5\right.$-cyclooctadiene or ${ }^{t} \mathrm{bpy}$, $\mathrm{OTf}=$ trifluoromethanesulfonate) likely proceeds via the generation of HOTf, which is the active catalyst, has been disclosed. ${ }^{30}$

The hydrophenylation of ethylene ( $0.1 \mathrm{MPa})$ using $0.025 \mathrm{~mol} \%$ $\mathrm{HBAr}_{4}{ }_{4}$ results in $\sim 1 \mathrm{TO}$ of ethylbenzene after $16 \mathrm{~h}$ at $120^{\circ} \mathrm{C}$. In addition, catalysis with $\mathbf{1}$ in the presence of 2,6-di-tert-butyl-4methylpyridine (1.5 equiv relative to $\mathbf{1}$ ), which gave $16.8 \mathrm{TO}$ of ethylbenzenes after $4 \mathrm{~h}$, was not suppressed. These results provide strong evidence against the in situ generation of a Brønsted acid serving as the active catalyst using $\left[\left({ }^{t} \mathrm{bpy}\right) \mathrm{Pt}(\mathrm{L})(\mathrm{Ph})\right]^{+}$systems.

We propose two possible mechanisms for ethylene hydrophenylation by $\left[\left({ }^{t} \mathrm{bpy}\right) \mathrm{Pt}(\mathrm{Ph})\right]^{+}$(Scheme 7 ) with benzene $\mathrm{C}-\mathrm{H}$ activation as the rate-determining step in each (rate-limiting $\mathrm{C}-\mathrm{H}$ coordination is equally viable, but this change does not impact the analysis of the proposed pathway). Both cycles are initiated by the substitution of THF, $\mathrm{NC}_{5} \mathrm{~F}_{5}$ or $\mathrm{NCMe}$ from the catalyst precursor with ethylene to give $\left[\left({ }^{t} \mathrm{bpy}\right) \mathrm{Pt}\left(\eta^{2}-\mathrm{C}_{2} \mathrm{H}_{4}\right)(\mathrm{Ph})\right]^{+}$. 
Insertion of ethylene into the $\mathrm{Pt}-$ phenyl bond generates the coordinatively unsaturated complex $\left[\left({ }^{t} \text { bpy }\right) \mathrm{Pt}\left(\mathrm{CH}_{2} \mathrm{CH}_{2} \mathrm{Ph}\right)\right]^{+}$. The coordination of ethylene to $\left[\left({ }^{t} \mathrm{bpy}\right) \mathrm{Pt}\left(\mathrm{CH}_{2} \mathrm{CH}_{2} \mathrm{Ph}\right)\right]^{+}$ forms $\left[\left({ }^{t} \mathrm{bpy}\right) \mathrm{Pt}\left(\mathrm{CH}_{2} \mathrm{CH}_{2} \mathrm{Ph}\right)\left(\eta^{2}-\mathrm{C}_{2} \mathrm{H}_{4}\right)\right]^{+}$(4), which has been identified by ${ }^{1} \mathrm{H}$ NMR spectroscopy as the catalyst resting state. In mechanism A, the catalyst resting state is incorporated into the catalytic cycle, and the subsequent exchange of ethylene for benzene occurs through an associative process to yield $\left[\left({ }^{t} \text { bpy }\right) \mathrm{Pt}\left(\mathrm{CH}_{2} \mathrm{CH}_{2} \mathrm{Ph}\right)\left(\eta^{2}-\mathrm{C}_{6} \mathrm{H}_{6}\right)\right]^{+}$. In mechanism $\mathrm{B}$, the formation of 4 removes $\mathrm{Pt}(\mathrm{II})$ from the catalytic cycle. Dissociation of ethylene from 4 allows re-entry of $\mathrm{Pt}(\mathrm{II})$ into the cycle

Scheme 5. Two Possible Mechanisms for the Formation of 4 from 1 and Ethylene $\left\{[\mathrm{Pt}]=\left[\left({ }^{t} \mathrm{bpy}\right) \mathrm{Pt}\right]\right\}$; Kinetic Data Are Consistent with the Associative Pathway

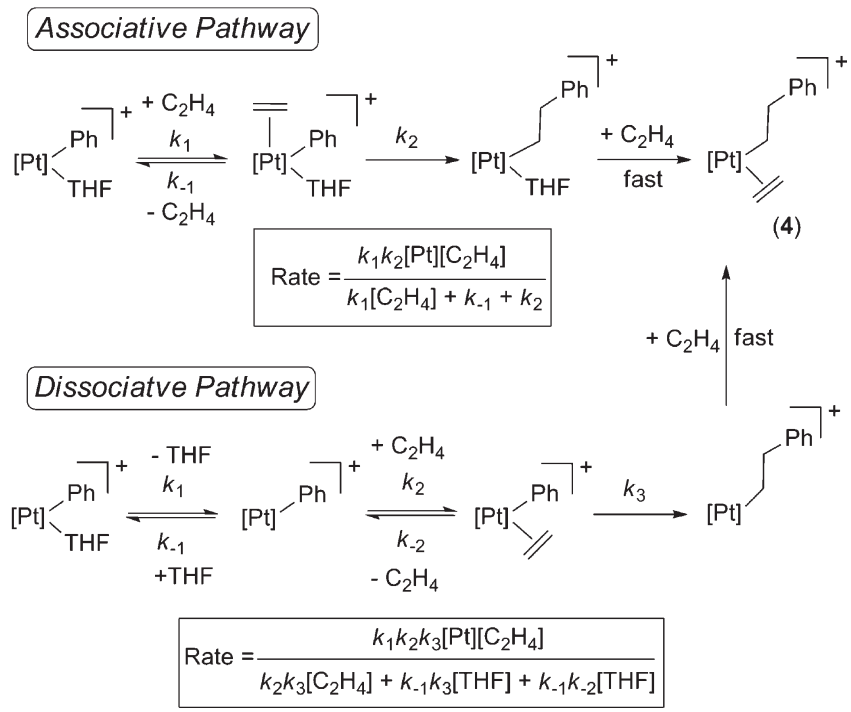

and is followed by the coordination of benzene to a threecoordinate intermediate, which precedes rate-determining $\mathrm{C}-\mathrm{H}$ activation. Subsequent aromatic $\mathrm{C}-\mathrm{H}$ activation with transfer of the $\mathrm{H}$ atom from benzene to the phenethyl ligand produces coordinated ethylbenzene, which is displaced by ethylene, regardless of the pathway (e.g., associative versus dissociative ligand exchange), to regenerate the catalyst.

Rate laws for the two mechanisms in Scheme 7 were derived using the King-Altman method. ${ }^{83}$ The derived rate laws are shown in Scheme 7 (for derivations, see Supporting Information). Since kinetic experiments demonstrated kinetic saturation at $\sim 2 \mathrm{M}$ benzene (Figure 4 ), and the catalytic reactions are performed in neat benzene $(\sim 11 \mathrm{M})$, we assume that terms containing concentration in benzene in the denominator would dominate. This provides the simplified forms of the rate laws shown in Scheme 7. Both of the rate laws predict saturation kinetics for ethylene and a first-order dependence on catalyst concentration, which are consistent with experimental observations; however, the kinetic experiments do not allow us to differentiate between mechanisms $\mathrm{A}$ and $\mathrm{B}$.

Goldberg et al. have reported a non-Friedel-Crafts mechanism for charge neutral $\mathrm{Pt}(\mathrm{II})$ catalysts supported by pyridylpyrrolyl ligands. ${ }^{21}$ Evidence suggests that ethylbenzene is produced from the reaction of (dmpp) $\mathrm{Pt}\left(\mathrm{CH}_{2} \mathrm{CH}_{2} \mathrm{Ph}\right)\left(\eta^{2}-\mathrm{C}_{2} \mathrm{H}_{4}\right)$ with benzene via orthometalation of the phenethyl ligand to form (dmpp) Pt $\left(o-\mathrm{C}_{6} \mathrm{H}_{4} \mathrm{Et}\right)$, followed by $\mathrm{C}-\mathrm{H}$ activation of coordinated benzene to release ethylbenzene. These results and proposed mechanism are similar to those reported by De Renzi et al. for stoichiometric reactions that involve ethylene insertion into cationic Pt-Ph bonds. ${ }^{77,84}$ The findings of our study are consistent with $\mathrm{C}-\mathrm{H}$ activation of coordinated benzene being the predominant mode of producing ethylbenzene, but the isotopic labeling studies indicate that cyclometalation of the phenethyl ligand is competitive (see Supporting Information for details).

Scheme 6. Calculated Energetics ( $\Delta G$ in THF, kcal/mol) for Two Possible Mechanisms for Ethylene Insertion into Pt-Ph Bond Starting from $[(\mathrm{bpy}) \mathrm{Pt}(\mathrm{Ph})(\mathrm{THF})]\left[\mathrm{BAr}^{\prime}{ }_{4}\right]\left(\mathbf{1}^{\prime}\right)$

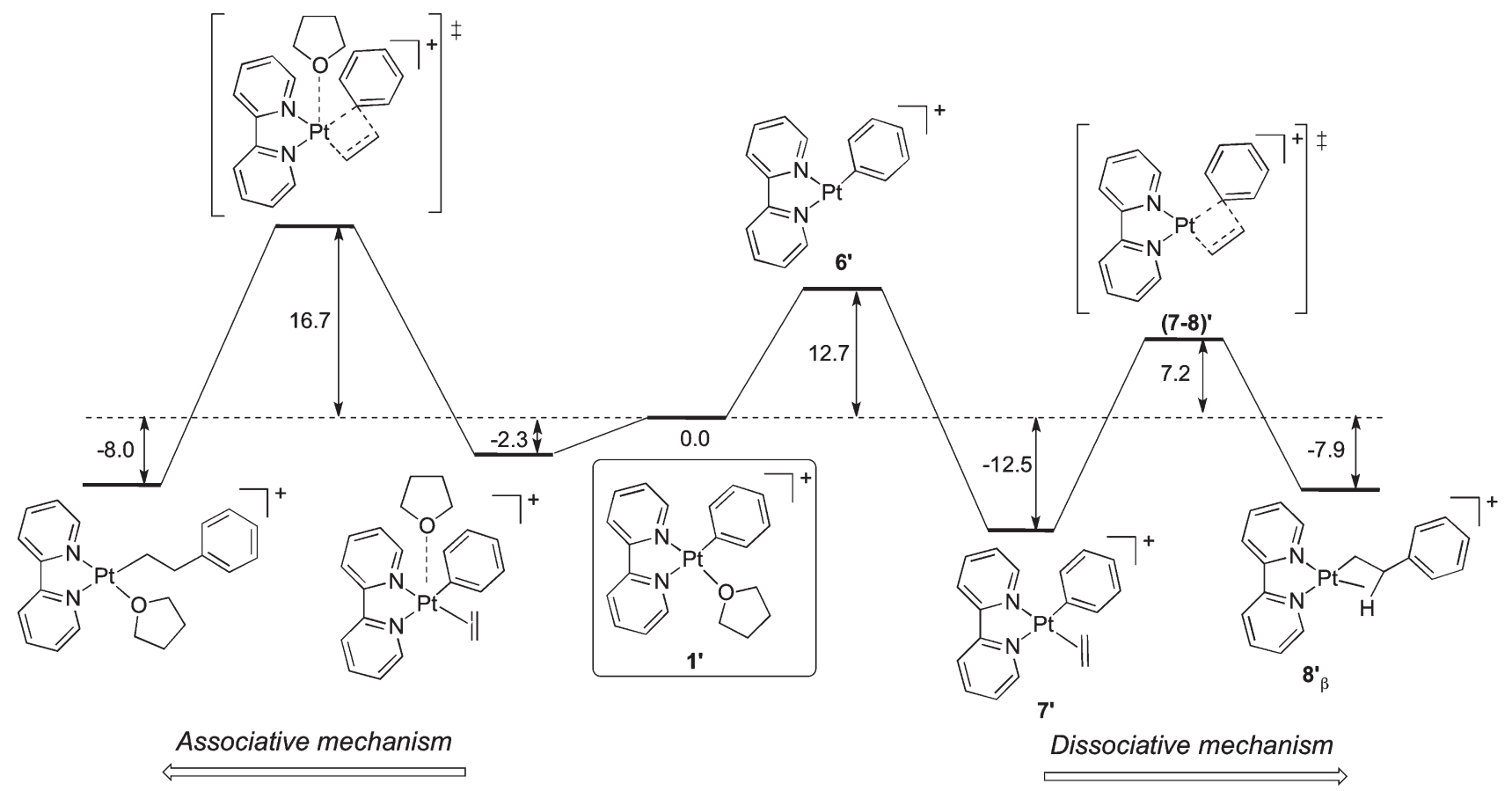




\section{Scheme 7. Two Proposed Mechanisms for Ethylene Hydrophenylation Catalyzed by $\left[\left({ }^{t} \mathrm{bpy}\right) \mathrm{Pt}(\mathrm{Ph})\right]^{+}$}

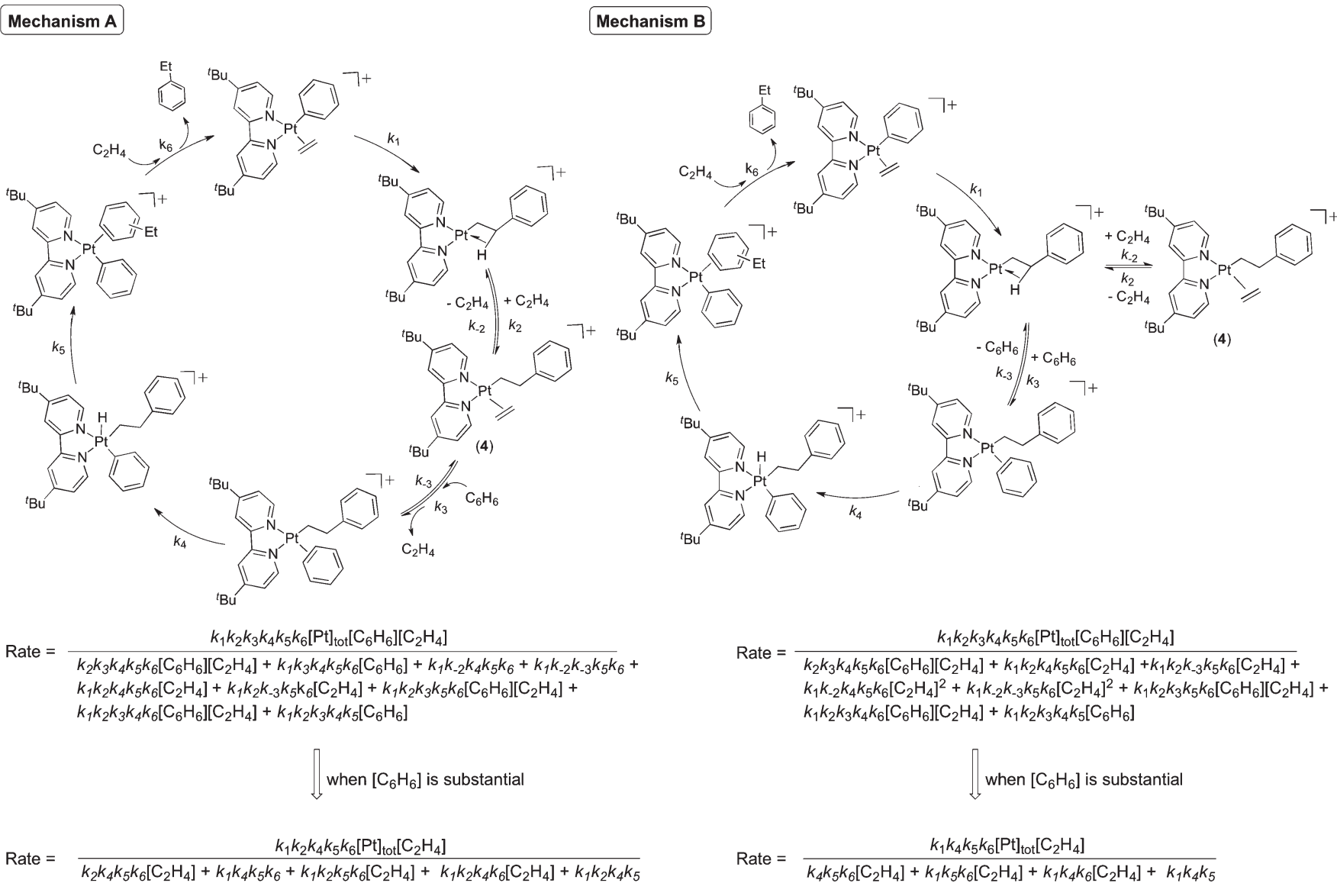

Calculated Energetics of Ethylene Hydrophenylation. The energetics of the proposed catalytic cycle were probed using DFT calculations (Scheme 8). Complex 4 has been identified experimentally as the catalyst resting state, and our DFT calculations suggest it is the lowest energy species in Scheme 8. Dissociation of ethylene from $4^{\prime}$ produces $\mathbf{8}^{\prime}$, which has two calculated conformers, a $\pi$ complex $\left(\mathbf{8}_{\boldsymbol{\pi}}^{\prime}\right)$ and a $\beta$-agostic $\left(\mathbf{8}_{\boldsymbol{\beta}}^{\prime}\right)$ structure (Figure 13). Complex $\mathbf{8}_{\boldsymbol{\pi}}^{\prime}$ and $\mathbf{8}_{\boldsymbol{\beta}}^{\prime}$ are 7.9 and $12.9 \mathrm{kcal} / \mathrm{mol}$, respectively, less favorable than $4^{\prime}$. In the latter conformer, one of the benzylic $\mathrm{C}-\mathrm{H}$ bonds of the phenethyl ligand occupies the vacant site in the $\mathrm{Pt}$ coordination sphere in an agostic interaction with the metal center, as opposed to $\eta^{2}$-coordination through a $\mathrm{C}=\mathrm{C}$ bond of the phenyl group for $\mathbf{8}^{\prime}{ }_{\boldsymbol{\pi}}$. Conformer $\mathbf{8}_{\boldsymbol{\pi}}^{\prime}$ is calculated to be more stable than $\mathbf{8}_{\boldsymbol{\beta}}^{\prime}$ by $5 \mathrm{kcal} / \mathrm{mol}$. The calculated $\beta$-agostic structure for $\mathbf{8}_{\boldsymbol{\beta}}^{\prime}$ shows a lengthening of one of the $\mathrm{C}-\mathrm{H}$ bonds $\left(1.33 \AA\right.$ ) of the $\beta-\mathrm{CH}_{2}$ group (Figure 13) by $0.2 \AA$ versus a typical $\mathrm{C}-\mathrm{H}$ bond length for $\mathbf{8}_{\boldsymbol{\beta}}^{\prime}$. The $\mathrm{C}_{\mathrm{sp} 3}-\mathrm{C}_{\mathrm{sp} 3}$ bond length for $\mathbf{8}_{\boldsymbol{\beta}}^{\prime}$ is calculated to be relatively short at $1.49 \AA$, suggesting some $[(\text { bpy }) \operatorname{Pt}(\mathrm{H})(\text { styrene })]^{+}$character for this stationary point.

The complex $\left[(\mathrm{bpy}) \mathrm{Pt}\left(\mathrm{CH}_{2} \mathrm{CH}_{2} \mathrm{Ph}\right)\right]^{+}$(either $\mathbf{8}_{\boldsymbol{\beta}}^{\prime}$ or $\mathbf{8}_{\boldsymbol{\pi}}^{\prime}$ ) may coordinate and subsequently activate benzene for $\mathrm{C}-\mathrm{H}$ bond cleavage. The $\Delta G$ for binding of benzene to form [ (bpy)$\left.\mathrm{Pt}\left(\mathrm{CH}_{2} \mathrm{CH}_{2} \mathrm{Ph}\right)\left(\eta^{2}-\mathrm{C}_{6} \mathrm{H}_{6}\right)\right]^{+}$is calculated to be endergonic at $+12.8 \mathrm{kcal} / \mathrm{mol}$ relative to $\mathbf{8}^{\prime}{ }_{\pi}$ and $+20.7 \mathrm{kcal} / \mathrm{mol}$ from $4^{\prime}$ (Scheme 8 ). The calculated $\Delta G^{*}$ for benzene $\mathrm{C}-\mathrm{H}$ activation by an oxidative addition/reductive elimination pathway is $18.0 \mathrm{kcal} / \mathrm{mol}$ from the benzene complex $\left[(\text { bpy }) \mathrm{Pt}\left(\mathrm{CH}_{2} \mathrm{CH}_{2} \mathrm{Ph}\right)\left(\eta^{2}-\mathrm{C}_{6} \mathrm{H}_{6}\right)\right]^{+}$. Two low energy conformations of $[(\mathrm{bpy}) \mathrm{Pt}(\mathrm{Ph})(\text { ethylbenzene })]^{+}$ $\left(9^{\prime}\right)$ were isolated via calculations, one in which the ethylbenzene coordinates by an agostic interaction with the $\mathrm{C}-\mathrm{H}$ bond of its methyl group, $\mathbf{9}^{\prime}$ ag, and an $\eta^{2}-C, C \pi$-bonded conformation, $\mathbf{9}^{\prime}{ }_{\pi}$. The latter is calculated to be more stable by $7.9 \mathrm{kcal} / \mathrm{mol}$ (Scheme 9). Thus, it appears reasonable to propose that $\mathbf{9}^{\prime}$ ag will be the initial product of benzene $\mathrm{C}-\mathrm{H}$ activation by $\left[\left({ }^{t} \mathrm{bpy}\right) \mathrm{Pt}\left(\mathrm{CH}_{2} \mathrm{CH}_{2} \mathrm{Ph}\right)\right]^{+}$, but that $9^{\prime}$ ag will likely convert to $9^{\prime}{ }_{\boldsymbol{\pi}}$ or a related $\pi$-arene adduct of ethylbenzene. The ethylbenzene product is released and $[(\text { bpy }) \mathrm{Pt}(\mathrm{Ph})]^{+}$is reformed. Loss of ethylbenzene from $\mathbf{9}^{\prime}{ }_{\boldsymbol{\pi}}$ was calculated to be endergonic by only $4.4 \mathrm{kcal} / \mathrm{mol}$ (Scheme 8 ). Consistent with the experimental observation of a KIE for catalysis with perprotio versus perdeuterobenzene (see above), the transition state for benzene $\mathrm{C}-\mathrm{H}$ activation is calculated to be the highest energy species on the reaction coordinate. As discussed above, the primary $\mathrm{KIE}\left(k_{\mathrm{H}} / k_{\mathrm{D}}\right)$ of $1.8(4)$ is sufficiently large to suggest ratedetermining $\mathrm{C}-\mathrm{H} / \mathrm{D}$ activation rather than $\mathrm{C}-\mathrm{H} / \mathrm{D}$ coordination; however, the deviation of \pm 0.4 does not allow definitive differentiation between these two elementary reaction steps.

Study of Multiple Insertions of Ethylene. From complex 4, insertion of ethylene into the $\mathrm{Pt}-\mathrm{CH}_{2} \mathrm{CH}_{2} \mathrm{Ph}$ bond and subsequent benzene $\mathrm{C}-\mathrm{H}$ activation would form butylbenzene. In fact, using $\mathrm{TpRu}(\mathrm{CO})(\mathrm{NCMe})(\mathrm{Ph})$ as a catalyst precursor for the hydrophenylation of ethylene produces small amounts of butylbenzene at ethylene pressures $\geq 1.7 \mathrm{MPa}^{18}$ Under the conditions probed for the Pt systems, including ethylene pressure up to $2.1 \mathrm{MPa}$ at $100{ }^{\circ} \mathrm{C}$, no evidence of butylbenzene is detected. The lack of butylbenzene production by the Pt catalyst is consistent with previous observations that suggest olefin 
Scheme 8. Comparison of Calculated Gibbs Free Energies (kcal/mol, in THF) for Proposed Intermediates and Transition States in Catalytic Ethylene Hydrophenylation by $\left[(\text { bpy }) \mathrm{Pt}\left(\mathrm{CH}_{2} \mathrm{CH}_{2} \mathrm{Ph}\right)\left(\eta^{2}-\mathrm{C}_{2} \mathrm{H}_{4}\right)\right]^{+}$

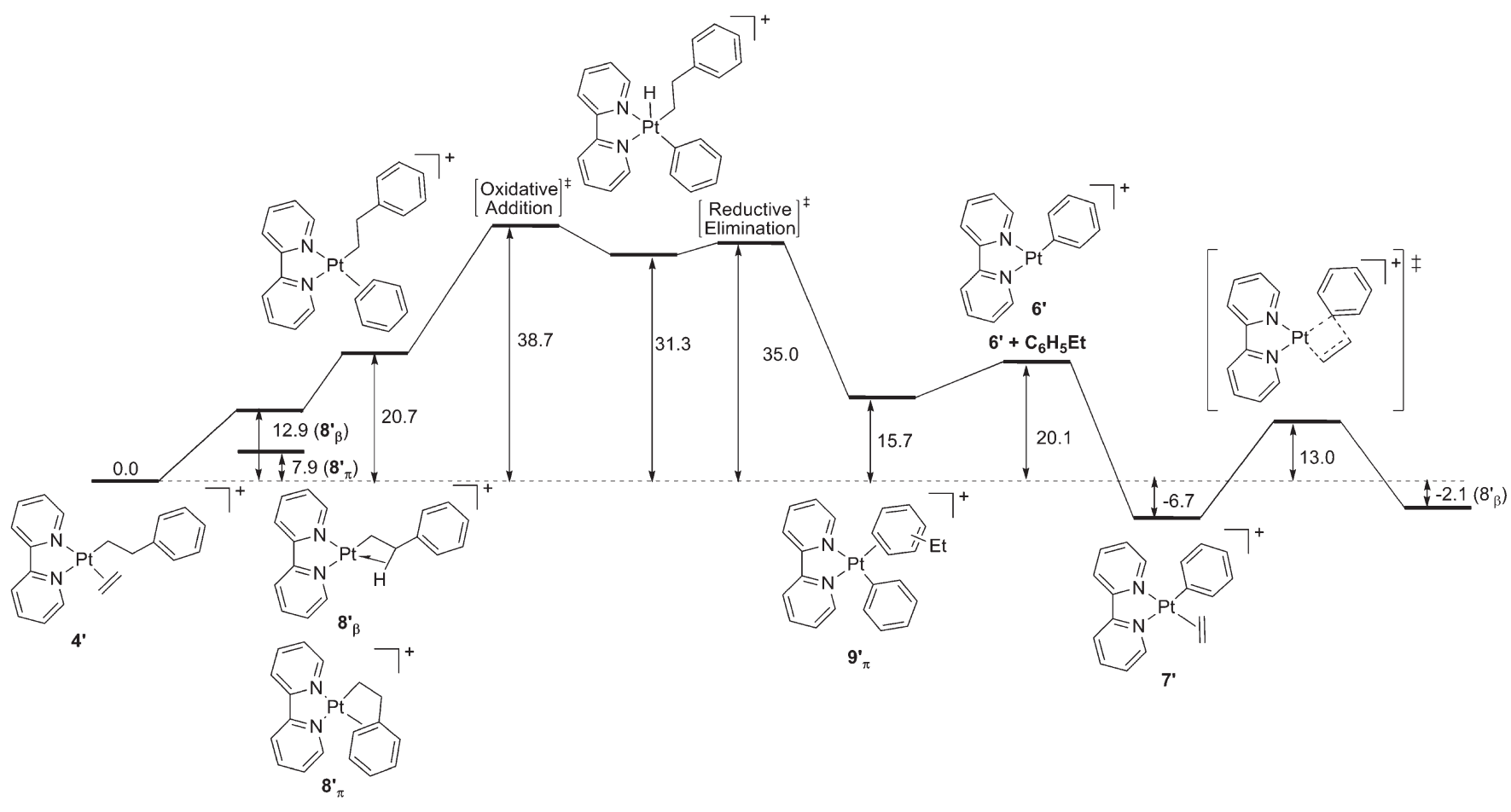

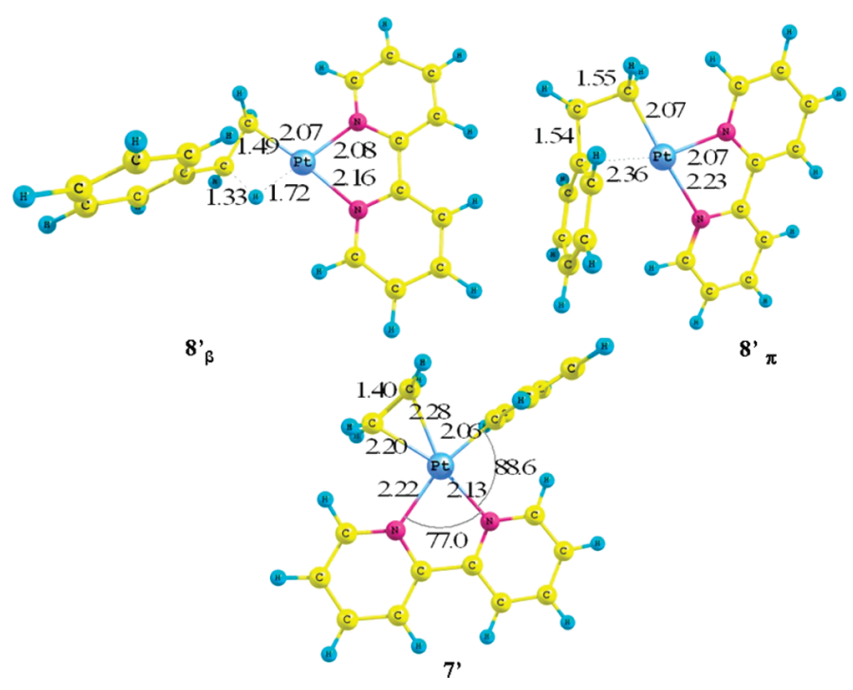

Figure 13. DFT calculated structures for $\left[(\mathrm{bpy}) \mathrm{Pt}(\mathrm{Ph})\left(\eta^{2}-\mathrm{C}_{2} \mathrm{H}_{4}\right)\right]^{+}$ $\left(7^{\prime}\right)$ and the two conformers of the resulting product $[(\mathrm{bpy}) \mathrm{Pt}$ $\left.\left(\mathrm{CH}_{2} \mathrm{CH}_{2} \mathrm{Ph}\right)\right]^{+}\left(\mathbf{8}_{\boldsymbol{\beta}}^{\prime}\right.$ and $\left.\mathbf{8}_{\boldsymbol{\pi}}^{\prime}\right)$.

insertion into $\mathrm{Pt}(\mathrm{II})$ - aryl bonds is more facile than insertion into $\mathrm{Pt}(\mathrm{II})$ - alkyl bonds. ${ }^{74,75,77}$

From the solid-state structure of complex 4, ethylene insertion would require initial rotation of the ethylene such that the $\mathrm{C}=\mathrm{C}$ bond axis, which is perpendicular to the square plane in 4 (see Figure 9), becomes coplanar with the $\mathrm{Pt}-\mathrm{C}_{\mathrm{sp} 3}$ bond of the phenethyl ligand. The ${ }^{1} \mathrm{H}$ NMR spectrum of $\mathbf{4}$ at room temperature reveals a single resonance due to the coordinated ethylene at $4.14 \mathrm{ppm}$. This reveals either rapid ethylene rotation on the NMR time scale or facile and reversible ethylene dissociation. The observation of $\mathrm{Pt}$ satellites for the resonance at $4.14 \mathrm{ppm}$ indicates that ethylene dissociation is not occurring and, hence, the exchange of ethylene hydrogen atoms is likely due to fast rotation about the $\mathrm{Pt}$-ethylene bond, which has been reported for related $\mathrm{Pt}(\mathrm{II})$ systems. ${ }^{85}$ Cooling a $\mathrm{CD}_{2} \mathrm{Cl}_{2}$ solution of 4 results in decoalescence of the single resonance for coordinated ethylene into two broad resonances. At temperatures below $-60{ }^{\circ} \mathrm{C}$, the $\Delta \delta$ for the two resonances of coordinated ethylene does not change. The coalescence temperature is observed at $-33.4{ }^{\circ} \mathrm{C}$ (Figure 14), which gives $k=110 \mathrm{~s}^{-1}$ and $\Delta G^{\ddagger}$ of $11.7 \mathrm{kcal} / \mathrm{mol}$. The calculated energy of the rotamer with ethylene parallel to the square plane is $12.4 \mathrm{kcal} / \mathrm{mol}$ (see below), which is close to the experimental rotational barrier.

Upon addition of one equivalent of ethylene (as measured by NMR integration) to a solution $\left(\mathrm{CD}_{2} \mathrm{Cl}_{2}\right)$ of 4 at room temperature, the coordinated ethylene peak shifts downfield and a time-averaged resonance for free and coordinated ethylene is observed at $\sim 4.8 \mathrm{ppm}$. Decoalescence of the resonances is not observed after cooling $\left(-90^{\circ} \mathrm{C}\right)$ the solution. These data are consistent with rapid exchange between free and coordinated ethylene (eq 5). Using the known chemical shifts for coordinated and free ethylene, an upper limit of $\sim 8$ $\mathrm{kcal} / \mathrm{mol}$ can be placed on the rate of ethylene exchange. $\Delta G^{\ddagger}$ values for related systems ranged from $\sim 14.5 \mathrm{kcal} / \mathrm{mol}$ to $<9.5 \mathrm{kcal} / \mathrm{mol}{ }^{85}$

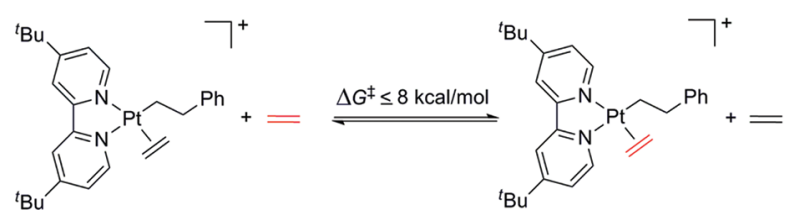

We attempted to calculate the energetics of a second insertion of ethylene from $\left[(\text { bpy }) \mathrm{Pt}\left(\mathrm{CH}_{2} \mathrm{CH}_{2} \mathrm{Ph}\right)\left(\eta^{2}-\mathrm{C}_{2} \mathrm{H}_{4}\right)\right]^{+}$. A conformation 
Scheme 9. DFT Calculated Structures for $\left[(\mathrm{bpy}) \operatorname{Pt}\left(\boldsymbol{\eta}^{2}-C, C\right.\right.$ $\left.\left.\mathrm{C}_{6} \mathrm{H}_{5} \mathrm{Et}\right)(\mathrm{Ph})\right]^{+}\left(9^{\prime}{ }_{\pi}\right)$ and $\left[(\mathrm{bpy}) \mathrm{Pt}\left(\eta^{2}-\mathrm{C}, \mathrm{H}^{-} \mathrm{C}_{6} \mathrm{H}_{5} \mathrm{Et}\right)(\mathrm{Ph})\right]^{+}$ $\left(9^{\prime}{ }_{\text {ag }}\right)$ with the Relative Energy Difference between Them $(\mathrm{kcal} / \mathrm{mol})$
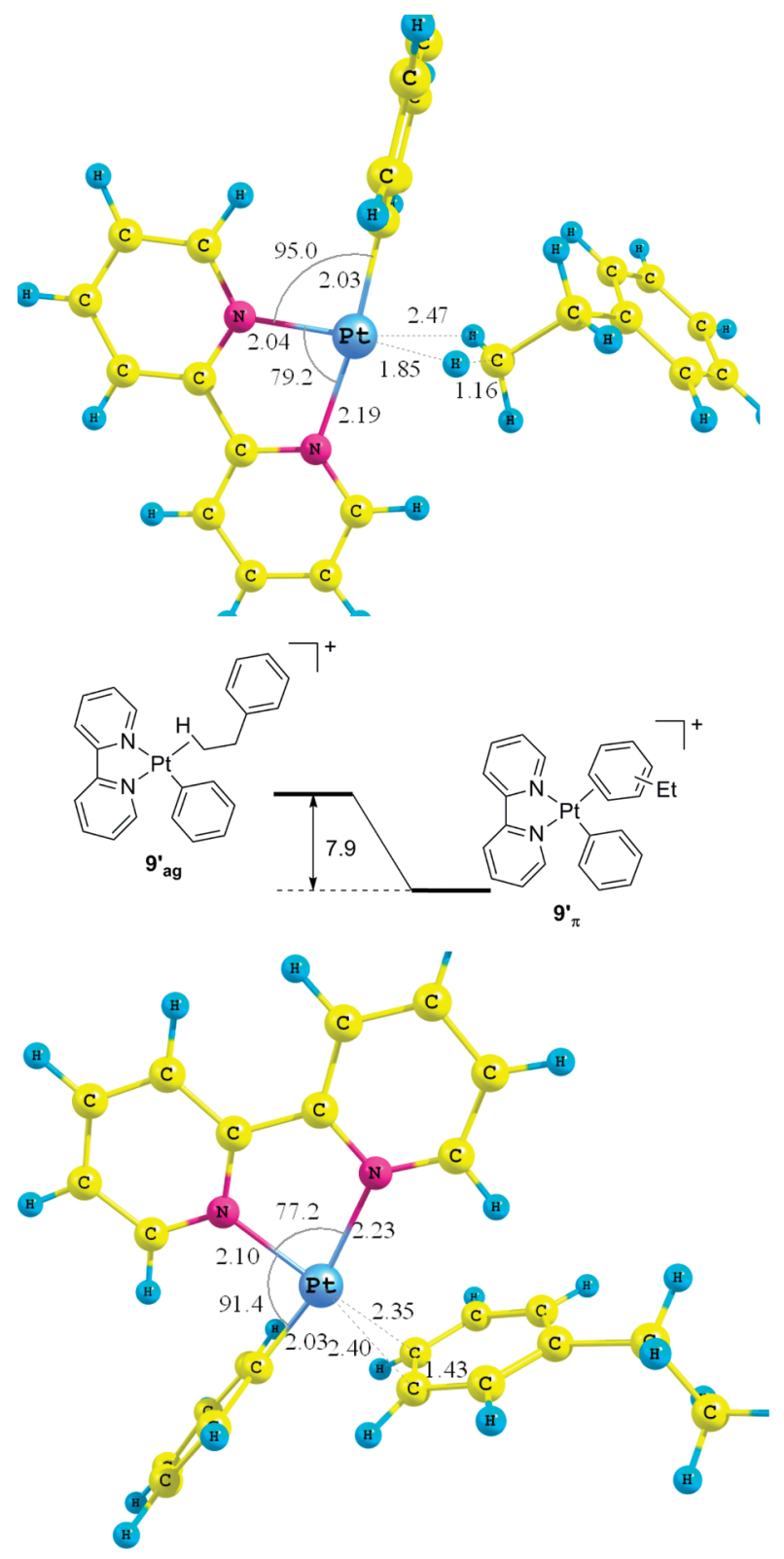

of the catalyst resting state in which the ethylene is rotated by approximately $90^{\circ}$ was found, and this rotamer is calculated to be $12.4 \mathrm{kcal} / \mathrm{mol}$ higher than $4^{\prime}$, consistent with the measured VTNMR rotational barrier $\left(\Delta G^{\ddagger}=11.7 \mathrm{kcal} / \mathrm{mol}\right)$. The subsequent transition state wherein the ethylene inserts to form a phenbutyl ligand was not found computationally. Multiple conformational searches for the transition state all yield either transition states already observed or dissociation of the ethylene moiety. The most plausible explanation for these results is steric hindrance brought about by the hydrogen atoms of the phenethyl ligand, which are absent on the phenyl $\mathrm{sp}^{2}$ carbon for $\mathrm{C}=\mathrm{C}$ insertion into the $\mathrm{Pt}-\mathrm{Ph}$ bond. The $\Delta G$ for a consecutive insertion of ethylene is calculated to be $15.6 \mathrm{kcal} / \mathrm{mol}$ relative to the resting state, $4^{\prime}$ (Scheme 10).
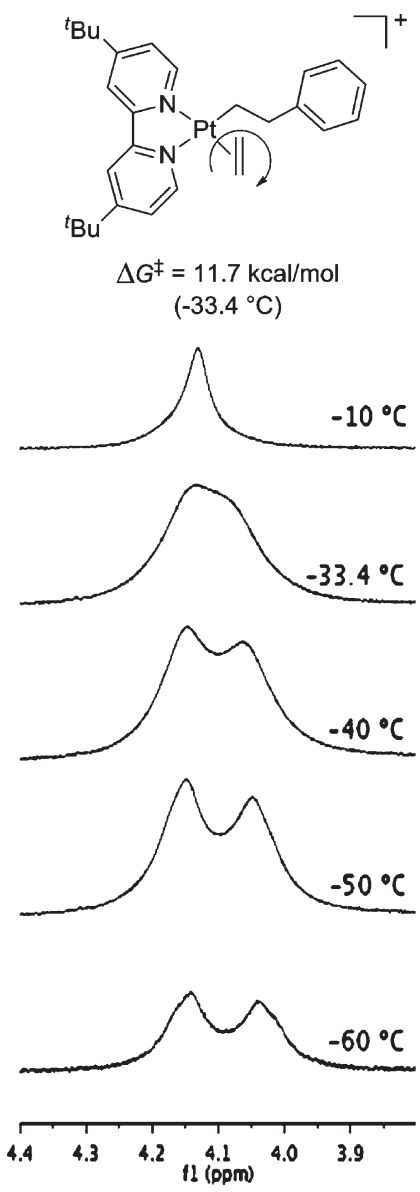

Figure 14. Variable-temperature ${ }^{1} \mathrm{H}$ NMR spectra in the region of resonances due to coordinated ethylene for $\left[\left({ }^{t}\right.\right.$ bpy $) \mathrm{Pt}\left(\mathrm{CH}_{2} \mathrm{CH}_{2} \mathrm{Ph}\right)\left(\eta^{2}\right.$ $\left.\left.\mathrm{C}_{2} \mathrm{H}_{4}\right)\right]\left[\mathrm{BAr}_{4}^{\prime}\right](4)$.

$\boldsymbol{\beta}$-Hydride Elimination. Although direct oxidative hydroarylation of olefins to form vinyl arenes is an attractive synthetic target, the formation of vinyl arenes via $\beta$-hydride elimination is potentially problematic when alkyl arenes are desired. Ethylene hydrophenylation performed by $1-3$ typically results in $\leq 1 \mathrm{TO}$ of styrene. The formation of styrene likely occurs via $\beta-\mathrm{H}$ elimination from the phenethyl complex (4). The thermolysis $\left(80{ }^{\circ} \mathrm{C}\right)$ of 4 with ethylene $(0.3 \mathrm{MPa})$ in nitromethane- $d_{3}$ produces styrene after approximately $10 \mathrm{~h}\left(\sim 78 \%\right.$ yield by ${ }^{1} \mathrm{H}$ NMR). Although the initial reaction mixture is complicated, the acetonitrile complex $\left[\left({ }^{t} \mathrm{bpy}\right) \mathrm{Pt}(\mathrm{Et})(\mathrm{NCMe})\right]\left[\mathrm{BAr}_{4}^{\prime}\right]$ (10) was isolated (70\% yield) after addition of NCMe to the reaction solution (Scheme 11). The formation of 10 was verified by comparison to an independently prepared sample. We presume that $\beta$-hydride elimination from 4 results in the formation of $\left[\left({ }^{t} \mathrm{bpy}\right) \mathrm{Pt}(\mathrm{H})\left(\eta^{2}\right.\right.$-styrene $\left.)\right]\left[\mathrm{BAr}^{\prime}{ }_{4}\right]$. The coordinated styrene is displaced by ethylene, which subsequently inserts into the $\mathrm{Pt}-\mathrm{H}$ bond. The coordination of an additional equivalent of ethylene would form $\left[\left({ }^{t} \mathrm{bpy}\right) \mathrm{Pt}(\mathrm{Et})\left(\eta^{2}-\mathrm{C}_{2} \mathrm{H}_{4}\right)\right]\left[\mathrm{BAr}^{\prime}{ }_{4}\right]$, but we have not been able to isolate this complex. These data are consistent with the following possibility: during catalysis, $\beta$-hydride elimination occurs but is reversible; however, eventually styrene dissociation occurs (regardless of the exact pathway), and under catalytic conditions, the resulting $\mathrm{Pt}-$ hydride decomposes. $\beta$-Hydride elimination from ${8^{\prime}}_{\pi}$ was calculated to have a $\Delta G^{\ddagger}$ of $5.0 \mathrm{kcal} / \mathrm{mol}$ and a $\Delta G$ of $-3.9 \mathrm{kcal} / \mathrm{mol}$ (Scheme 12). The formation of 
Scheme 10. Calculated Gibbs Free Energies ( $\mathrm{kcal} / \mathrm{mol}$ ) for Consecutive Ethylene Insertion from $4^{\prime}$

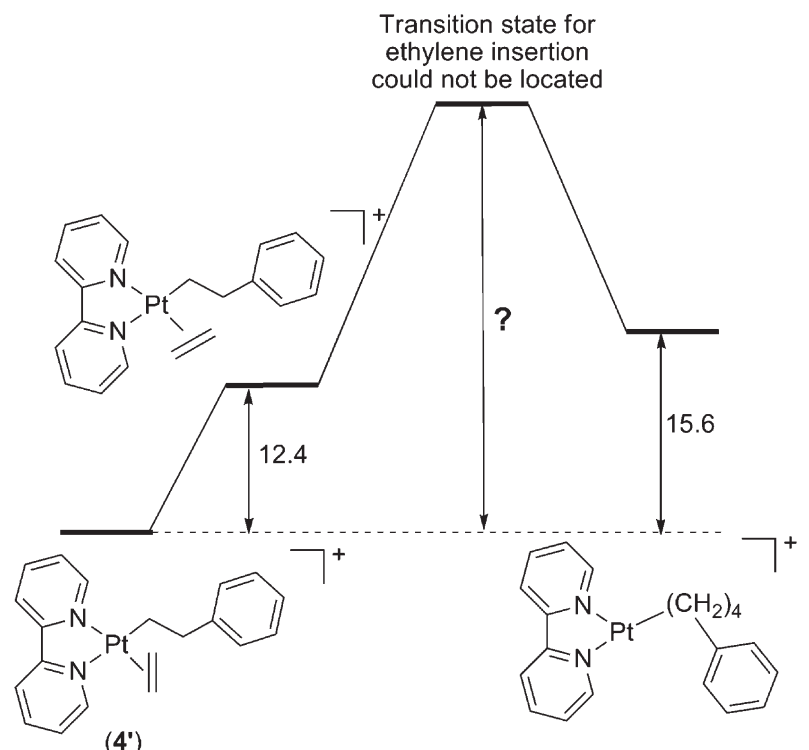

$\left(4^{\prime}\right)$

Scheme 11. Heating 4 in $\mathrm{CD}_{3} \mathrm{NO}_{2}$ Produces Styrene and a Pt-Ethyl Complex

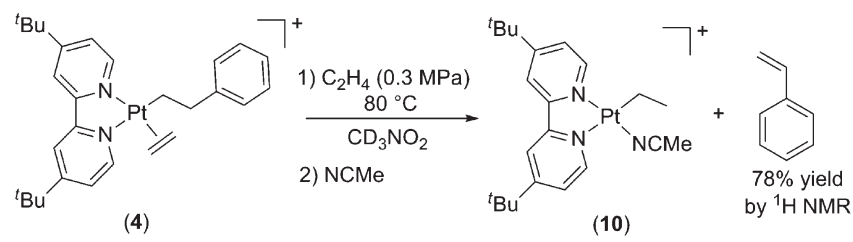

three-coordinate $[(\mathrm{bpy}) \mathrm{Pt}(\mathrm{H})]^{+}$via styrene dissociation is unfavorable with a calculated $\Delta G$ of $7.6 \mathrm{kcal} / \mathrm{mol}$ from $[(\mathrm{bpy}) \mathrm{Pt}$ $(\mathrm{H})\left(\eta^{2}\right.$-styrene $\left.)\right]^{+}$.

$\mathrm{C}-\mathrm{H}$ Bond Activation of Ethylene. A potentially problematic transformation for non-Friedel-Crafts olefin hydroarylation is $\mathrm{C}-\mathrm{H}$ activation of the coordinated olefin. Evidence for ethylene $\mathrm{C}-\mathrm{H}$ activation has not been observed experimentally using complexes $1-3$, but we have investigated this process computationally. Simulations suggest that vinyl $\mathrm{C}-\mathrm{H}$ activation via $\sigma$ bond metathesis is energetically more favorable by $1.4 \mathrm{kcal} / \mathrm{mol}$ over an oxidative addition/reductive elimination pathway. After the binding of ethylene to $[(\mathrm{bpy}) \mathrm{Pt}(\mathrm{Ph})]^{+}$to form complex $7^{\prime}$, a transition state for the activation of the vinylic $\mathrm{C}-\mathrm{H}$ bond is calculated to occur with a $\Delta G^{\ddagger}$ of $36.0 \mathrm{kcal} / \mathrm{mol}$ (Scheme 13). The resulting vinyl complex, $\left[(\right.$ bpy $) \mathrm{Pt}\left(\eta^{2}-C, C-\mathrm{C}_{6} \mathrm{H}_{6}\right)(\mathrm{CH}=$ $\left.\left.\mathrm{CH}_{2}\right)\right]^{+}$, has a $\Delta G$ of $+17.5 \mathrm{kcal} / \mathrm{mol}$ relative to $7^{\prime}$. The ensuing release of benzene and formation of $\left[(\text { bpy }) \mathrm{Pt}\left(\mathrm{CH}=\mathrm{CH}_{2}\right)\right]^{+}$has a calculated $\Delta G$ of $22.4 \mathrm{kcal} / \mathrm{mol}$ relative to $7^{\prime}$.

This barrier to vinyl $\mathrm{C}-\mathrm{H}$ activation is approximately 16.3 $\mathrm{kcal} / \mathrm{mol}$ higher than the calculated activation barrier for the insertion of $\mathrm{C}=\mathrm{C}$ into the $\mathrm{Pt}-\mathrm{Ph}$ bond (vide supra), which is nearly double the calculated $\Delta \Delta G^{\ddagger}$ of $8.6 \mathrm{kcal} / \mathrm{mol}$ for the same two reactions with $\mathrm{TpRu}(\mathrm{CO})\left(\eta^{2}-\mathrm{C}_{2} \mathrm{H}_{4}\right)(\mathrm{Ph})$ (Scheme 14). ${ }^{19}$ For $\mathrm{TpRu}\left(\mathrm{PMe}_{3}\right)\left(\eta^{2}-\mathrm{C}_{2} \mathrm{H}_{4}\right)(\mathrm{Ph})$ the calculated $\Delta \Delta G^{\neq}$for ethylene insertion and ethylene $\mathrm{C}-\mathrm{H}$ activation is only $3.1 \mathrm{kcal} / \mathrm{mol}$. As a result of the relatively low activation barrier for ethylene
Scheme 12. $\Delta G^{\prime}$ 's $(\mathrm{kcal} / \mathrm{mol})$ for Styrene Production via $\beta$-Elimination from $\mathbf{8}_{\boldsymbol{\beta}}^{\prime}$

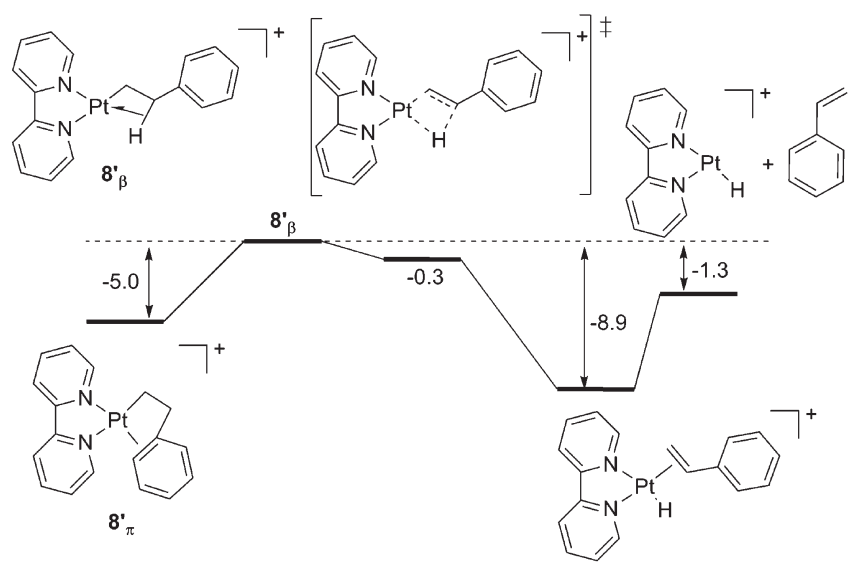

$\mathrm{C}-\mathrm{H}$ activation (compared with the $\Delta G^{\ddagger}$ for ethylene insertion) by $\mathrm{TpRu}\left(\mathrm{PMe}_{3}\right)\left(\eta^{2}-\mathrm{C}_{2} \mathrm{H}_{4}\right)(\mathrm{Ph})$, this system is not a catalyst for ethylene hydrophenylation. ${ }^{19}$ For $7^{\prime}$, the large kinetic preference for $\mathrm{C}=\mathrm{C}$ insertion over ethylene $\mathrm{C}-\mathrm{H}$ activation suggests substantial latitude with respect to potential strategies for catalyst refinement before vinylic $\mathrm{C}-\mathrm{H}$ activation becomes problematic for this family of $\mathrm{Pt}$ (II) catalysts, thus providing one major advantage over reported $\mathrm{Ru}(\mathrm{II})$ catalysts (Scheme 14).

Polyalkylation of Benzene. Ethylene hydrophenylation using complexes $1-3$ produces significant quantities of diethylbenzenes that account for approximately $20 \%$ of the total alkyl arene products (Table 1$)$. For the $\mathrm{Pt}$ catalysts $\left[\left({ }^{t} \mathrm{bpy}\right) \mathrm{Pt}(\mathrm{Ph})\right.$ $(\mathrm{L})]^{+}$, the ratio of diethylbenzenes to ethylbenzene is approximately invariant as a function of the identity of the ligand L. In contrast, only $3 \%$ of the total alkyl arene product is diethylbenzene for ethylene hydrophenylation using a Ir(III) catalyst, $^{20,28}$ and catalytic ethylene hydrophenylation using $\mathrm{TpRu}(\mathrm{CO})$ $(\mathrm{NCMe})(\mathrm{Ph})$ produces only trace amounts of diethylbenzene. $^{18,20}$ Polyalkylated benzenes produced during catalytic ethylene hydrophenylation using the $\mathrm{Pt}$ catalyst precursor (dmpp)PtMe $\mathrm{Pt}_{3}$ [dmpp = 3,5-dimethyl-2-(2-pyridyl)pyrrolide $]$ comprise $\sim 4 \%$ of the total alkyl arene product. ${ }^{21}$ One of the potential advantages of transition metal-catalyzed olefin hydroarylation (compared to Friedel-Crafts catalysis) is the inhibition of polyalkylation. Thus, we sought to determine the reason that $\left[\left({ }^{t} \text { bpy }\right) \mathrm{Pt}(\mathrm{Ph})(\mathrm{L})\right]^{+}$catalysts produce substantial quantities of diethylbenzenes. The simplest explanation is that the reaction of the Pt catalyst with ethylbenzene is substantially faster than the reaction with benzene. However, as delineated below, experimental data do not support this scenario.

The catalytic conversion of ethylbenzene and ethylene $(0.1$ $\mathrm{MPa}$ ) to diethylbenzenes by 1 at $100^{\circ} \mathrm{C}$ results in 5.8 turnovers after $4 \mathrm{~h}$, corresponding to a TOF of $0.4 \times 10^{-3} \mathrm{~s}^{-1}$; whereas the hydrophenylation of ethylene by 1 under identical conditions occurs with a TOF of $1.3 \times 10^{-3} \mathrm{~s}^{-1}$. Thus, the rate of ethylbenzene production from benzene is $\sim 3$ times faster than the rate of diethylbenzene formation from ethylbenzene, and the production of significant quantities of diethylbenzenes during the hydrophenylation of ethylene cannot be accounted for by reaction of the Pt catalyst with free ethylbenzene formed during the reaction.

A plausible mechanism to explain the production of diethylbenzenes is depicted in Scheme 15. The key steps follow benzene 
Scheme 13. Comparison of calculated Gibbs free energies (kcal/mol, THF) for ethylene insertion and ethylene $\mathrm{C}-\mathrm{H}$ activation by $\left[(\text { bpy }) \operatorname{Pt}(\mathrm{Ph})\left(\boldsymbol{\eta}^{2}-\mathrm{C}_{2} \mathrm{H}_{4}\right)\right]^{+}\left(7^{\prime}\right)$

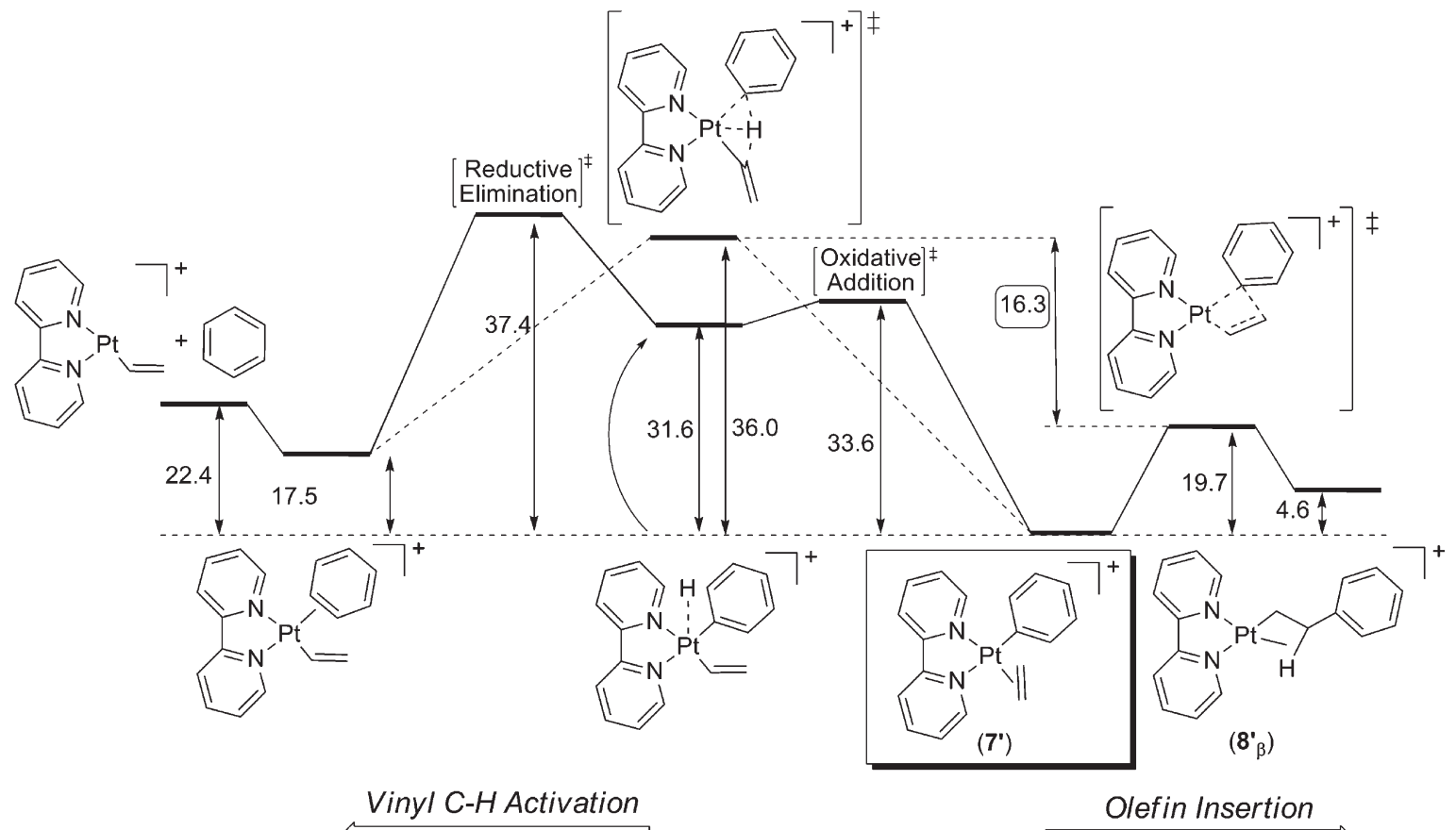

Scheme 14. Comparison of the Calculated $\Delta G^{\ddagger}(\mathrm{kcal} / \mathrm{mol})$ for Ethylene Insertion vs Ethylene $\mathrm{C}-\mathrm{H}$ Activation between Several Reported Ethylene Hydroarylation Catalysts, with the $\Delta \Delta G^{\ddagger}$ between the Two Transformations Highlighted

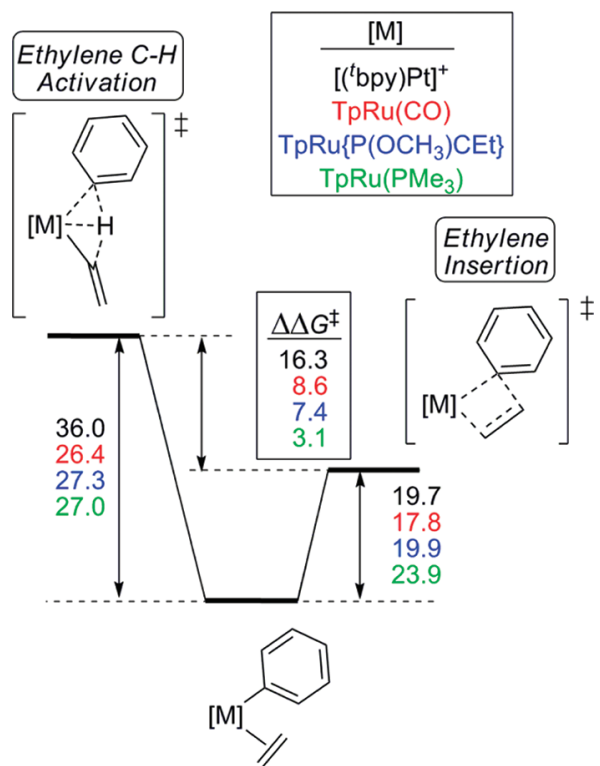

$\mathrm{C}-\mathrm{H}$ activation to produce $\left[\left({ }^{t} \mathrm{bpy}\right) \mathrm{Pt}\right.$ (ethylbenzene $\left.)(\mathrm{Ph})\right]^{+}(\mathbf{A}$ in Scheme 15). Dissociation of ethylbenzene from A completes the catalytic cycle for ethylene hydrophenylation. However, aromatic $\mathrm{C}-\mathrm{H}$ activation of ethylbenzene generates $\left[\left({ }^{t} \mathrm{bpy}\right) \mathrm{Pt}\right.$ $\left.\left(\mathrm{C}_{6} \mathrm{H}_{4} \mathrm{Et}\right)\left(\mathrm{C}_{6} \mathrm{H}_{6}\right)\right]^{+}(\mathbf{B}, 3$ isomers are possible due to regioselectivity of ethylbenzene $\mathrm{C}-\mathrm{H}$ activation). The conversion of $\mathrm{A}$ to
B requires the conversion of alkyl-coordinated ethylbenzene to an arene-coordinated system. Such a rearrangement of $\mathrm{C}-\mathrm{H}$ coordinated alkyl arene to a $\pi$-arene complex has been observed for late transition metals. ${ }^{86}$ From complex B, coordination and insertion of a second equivalent of ethylene with subsequent benzene $\mathrm{C}-\mathrm{H}$ activation leads to diethylbenzene. At $100^{\circ} \mathrm{C}$ and $0.1 \mathrm{MPa}$ of ethylene, the ratio of ethylbenzene to diethylbenzenes ranges from 4.4 to 4.8 , which indicates that the rate of ethylbenzene dissociation is only $\sim 4.5$ times faster than diethylbenzene formation. Hence, we suggest that relatively slow dissociation of ethylbenzene, regardless of whether this occurs by a net associative or dissociative process, allows opportunity for a second $\mathrm{C}-\mathrm{H}$ activation and, hence, formation of diethylbenzene. It is also feasible that diethylbenzene formation begins with an initial cyclometalation of the phenethyl ligand, as reported by Goldberg et al. for a related Pt system. ${ }^{21}$ However, in this pathway (Scheme 16) the formation of 1,3-diethylbenzene and 1,4-diethylbenzene would likely require that the $\mathrm{Pt}$ (II) complex coordinate ethylbenzene with sufficient lifetime to allow a second $\mathrm{C}-\mathrm{H}$ activation (and ethylene insertion) to compete with net dissociation of ethylbenzene; hence, complex $\mathbf{A}$ is still implicated as an intermediate.

Catalysis using a 1:1 ratio $(v: v)$ of $\mathrm{C}_{6} \mathrm{H}_{6}$ and $\mathrm{C}_{6} \mathrm{D}_{6}$ with $\mathrm{C}_{2} \mathrm{H}_{4}$ was anticipated to produce ethylbenzene- $d_{n}$ with $n=0,1,5$ and 6 , which would arise from ethylene insertion into either $\mathrm{Pt}-\mathrm{Ph}$ or $\mathrm{Pt}-\mathrm{Ph}-d_{5}$ followed by activation of either $\mathrm{C}_{6} \mathrm{H}_{6}$ or $\mathrm{C}_{6} \mathrm{D}_{6}$ (Scheme 17), as observed for the same experiment using TpRu(CO) $(\mathrm{NCMe}) \mathrm{Ph}$ as the catalyst. ${ }^{18}$ However, all isotopologues of ethylbenzene- $d_{n}$ with $n=0-6(\mathrm{~m} / z=106-112)$ were detected by GC/MS using complex 2. The observation of substantial $\mathrm{H} / \mathrm{D}$ exchange is consistent with our proposed mechanism for diethylbenzene formation in which relatively slow net dissociation of ethylbenzene from $\mathrm{Pt}$ (II) (regardless of the mechanism of 
Scheme 15. Proposed Pathway by Which Diethylbenzenes Are Formed during Catalytic Ethylene Hydrophenylation Catalyzed by $\left[\left({ }^{t} \mathrm{bpy}\right) \mathrm{Pt}(\mathrm{Ph})\right]^{+a}$

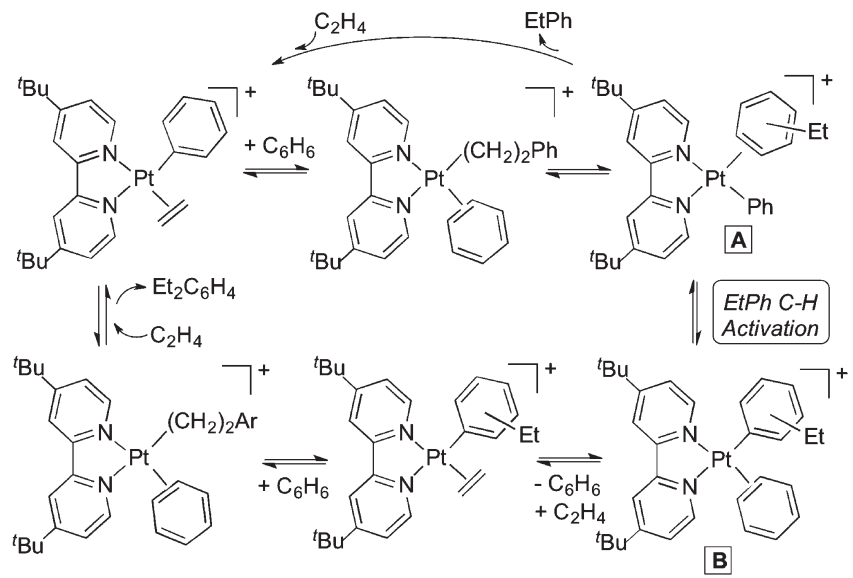

${ }^{a}\left(\mathrm{Ar}=\mathrm{C}_{6} \mathrm{H}_{4} \mathrm{Et}\right.$; note: three isomers of the $\mathrm{C}_{6} \mathrm{H}_{4} \mathrm{Et}$ ligand of $\mathbf{B}$ are possible).

dissociation) provides a pathway for $\mathrm{H} / \mathrm{D}$ scrambling to yield ethylbenzene- $d_{n}$ with $n=2,3$, and 4 in addition to the $n=0,1,5$, and 6 isotopes that are expected (Scheme 17).

Heating complex 4 in benzene $\left(100^{\circ} \mathrm{C}\right)$ results in quantitative production of ethylbenzene (by GC/MS) (eq 6). Importantly, GC/MS analysis of the reaction of 4 in $\mathrm{C}_{6} \mathrm{D}_{6}$ reveals the production of ethylbenzene- $d_{\mathrm{n}}(n=1-6)$. NMR spectroscopy and GC/MS analysis indicate that extensive deuteration does not occur in the ethyl fragment, other than the expected formation of $-\mathrm{CH}_{2} \mathrm{CH}_{2} \mathrm{D}$. If the conversion of $\mathbf{A}$ to $\mathbf{B}$ (Scheme 15) were inaccessible, then heating 4 in $\mathrm{C}_{6} \mathrm{D}_{6}$ should produce only ethylbenzene- $d_{1}$. The mass spectrum of ethylbenzene features peaks at mass range $m / z=106-113$ and fragmentation at mass range $m / z=91-97$, which indicates that $\mathrm{H} / \mathrm{D}$ scrambling occurs predominantly into the phenyl ring of ethylbenzene (Scheme 18). Ions in the range of $m / z=27-30$ were observed, which is indicative of the presence of $-\mathrm{CH}_{2} \mathrm{CH}_{2} \mathrm{D}(\mathrm{m} / z=30)$ fragments. There is no evidence of a peak at $m / z=31$ (or greater) due to ethyl- $d_{\mathrm{n}}(n \geq 2)$ fragments. The ${ }^{2} \mathrm{H}$ NMR spectrum of the reaction mixture supports the presence of a $-\mathrm{CH}_{2} \mathrm{CH}_{2} \mathrm{D}$ fragment $\left(\delta=1.03 \mathrm{ppm}\right.$ in the ${ }^{2} \mathrm{H}$ NMR spectrum $)$ and a lack of extensive H/D scrambling into the ethyl fragment, since a resonance consistent with deuterium incorporation into the benzylic position is not observed (Figure 15).

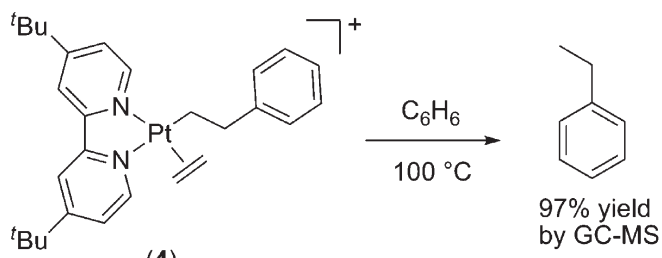

The addition of a Lewis base to the reaction of 4 with $\mathrm{C}_{6} \mathrm{D}_{6}$ might be expected to promote the loss of ethylbenzene from $\mathbf{A}$ (Scheme 15) via associative displacement and suppress the extent of $\mathrm{H} / \mathrm{D}$ exchange. Indeed, the addition of THF (100 equiv relative to 4) to the stoichiometric reaction of 4 in $\mathrm{C}_{6} \mathrm{D}_{6}$ results in a shift of the isotopic distribution from the major isotope of
Scheme 16. Alternative Pathway for Formation of Diethylbenzenes during Catalytic Ethylene Hydrophenylation Catalyzed by $\left[\left({ }^{t} \mathrm{bpy}\right) \mathrm{Pt}(\mathrm{Ph})\right]^{+}$

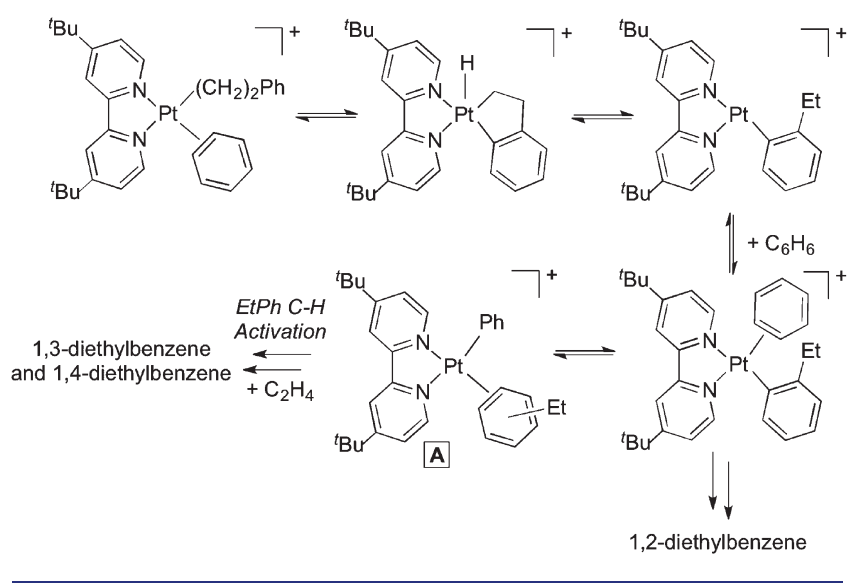

Scheme 17. Expected Isotopologues of Ethylbenzene- $d_{n}$ $(n=0,1,5,6)$ That Are Produced from Ethylene Insertion into a $\mathrm{Pt}-\mathrm{Ph}$ or $\mathrm{Pt}-\mathrm{Ph}-d_{5}$ and Subsequent $\mathrm{C}-\mathrm{H} / \mathrm{D}$ Activation of Either $\mathrm{C}_{6} \mathrm{H}_{6}$ or $\mathrm{C}_{6} \mathrm{D}_{6}{ }^{a}$
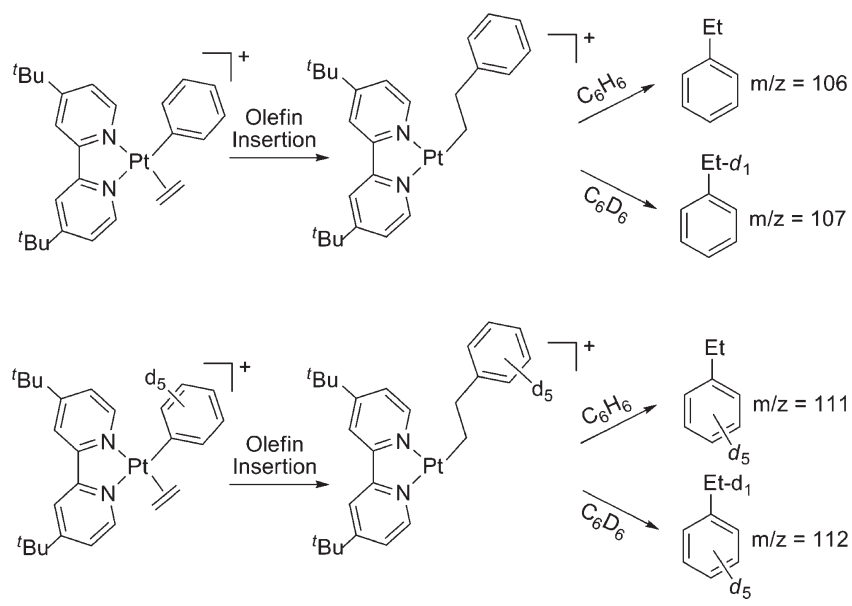

${ }^{a}$ In addition to isotopologues with $n=0,1,5$, and 6, those with $n=2,3$, and 4 are also observed.

$m / z=112$ to $m / z=107$. The addition of the Lewis base increases the prevalence of the lower mass ions $(m / z=105-109)$ compared to the reaction without its addition. The inhibition of isotopic scrambling by the addition of a Lewis base is most readily explained by an associative mechanism for exchange of ethylbenzene with THF and mirrors the observations of isotope exchange from protonation of (diimine) $\mathrm{Pt}(\mathrm{Me})_{2}$ using DOTf, as well as positional $o / m / p$ isomerization of $\mathrm{Pt}$ tolyl and xylyl complexes where NCMe was used as the Lewis base in both cases. ${ }^{39,40}$

To confirm the interpretation of the results of isotopic labeling, $\left[\left({ }^{t} \text { bpy }\right) \mathrm{Pt}\left(\mathrm{CH}_{2} \mathrm{CH}_{2} \mathrm{Ph}-d_{5}\right)\left(\eta^{2}-\mathrm{C}_{2} \mathrm{H}_{4}\right)\right]^{+}\left(4-d_{5}\right)$ was synthesized with an all deutero $\mathrm{Ph}$ moiety. The reaction of 4- $d_{5}$ in $\mathrm{C}_{6} \mathrm{H}_{6}$ produces isotopologues with a mass range $m / z=$ 106-111, with $m / z=106$ having the greatest abundance, which indicates substantial formation of per protio ethylbenzene by $H / D$ exchange. The observed selectivity for 
Scheme 18. Proposed Mechanism for H/D Scrambling that Occurs during the Thermolysis of $\left[\left({ }^{t} \mathrm{bpy}\right) \mathrm{Pt}\left(\mathrm{CH}_{2} \mathrm{CH}_{2} \mathrm{Ph}\right)\right.$ $\left.\left(\eta^{2}-\mathrm{C}_{2} \mathrm{H}_{4}\right)\right]\left[\mathrm{BAr}_{4}^{\prime}\right]$ in $\mathrm{C}_{6} \mathrm{D}_{6}$

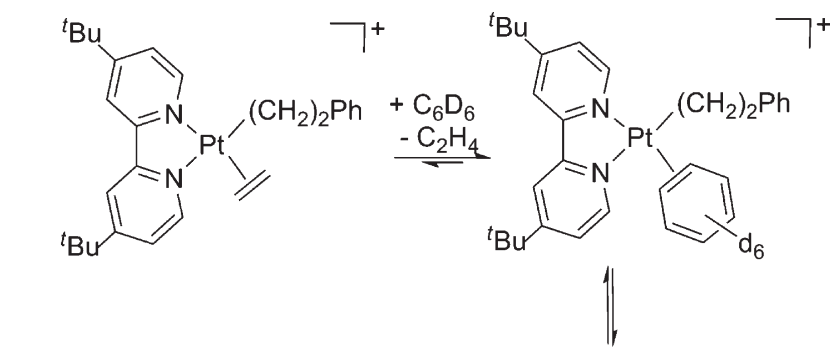

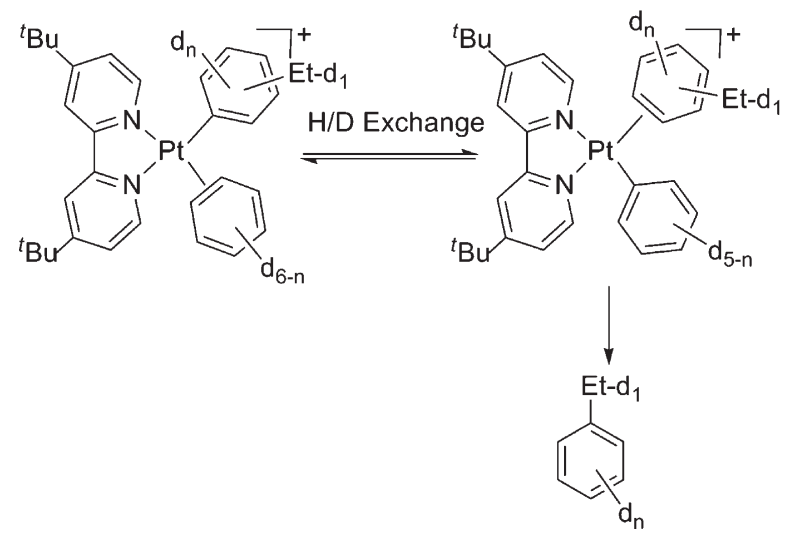

isotopologues of ethylbenzene is similar to that observed for the thermolysis of 4 in $\mathrm{C}_{6} \mathrm{D}_{6}$ with $\mathrm{H} / \mathrm{D}$ exchange occurring predominantly into the phenyl ring of ethylbenzene. Similar to 4 and $\mathrm{C}_{6} \mathrm{D}_{6}$, the addition of the Lewis base increases the prevalence of the higher mass ions $(m / z>108)$ compared to the reaction without its addition.

Benzene coordination and $\mathrm{C}-\mathrm{H}$ activation by $[(\mathrm{bpy}) \mathrm{Pt}-$ $\left.\left(\mathrm{CH}_{2} \mathrm{CH}_{2} \mathrm{Ph}\right)\right]^{+}$forms $\left[(\mathrm{bpy}) \mathrm{Pt}(\mathrm{Ph})\left(\eta^{2}-\mathrm{C}, \mathrm{C}-\mathrm{C}_{6} \mathrm{H}_{5} \mathrm{Et}\right)\right]^{+}\left(\mathrm{A}^{\prime}\right)$. Simulations were used to assess the potential for $\mathbf{A}^{\prime}$ to (a) undergo dissociation of ethylbenzene, (b) undergo a second aromatic $\mathrm{C}-\mathrm{H}$ activation event and (c) undergo $\mathrm{sp}^{3} \mathrm{C}-\mathrm{H}$ activation. The last process (i.e., c), which forms [(bpy)Pt$\left.\left(\mathrm{CH}_{2} \mathrm{CH}_{2} \mathrm{Ph}\right)\left(\eta^{2}-C, C-\mathrm{C}_{6} \mathrm{H}_{6}\right)\right]^{+}$, has a high calculated barrier $\left(\Delta G^{*}=27.5 \mathrm{kcal} / \mathrm{mol}\right)$, consistent with the absence of extensive $\mathrm{H} / \mathrm{D}$ scrambling into the ethyl fragment. The free energy for dissociation of ethylbenzene from $\mathbf{A}^{\prime}$ is calculated to be $12.5 \mathrm{kcal} / \mathrm{mol}$ (Scheme 19; these calculations are gas phase and thus the free energy of ethylbenzene dissociation is different from that in Scheme 8), while arene $\mathrm{C}-\mathrm{H}$ activation barriers are calculated to be $16.2 \mathrm{kcal} / \mathrm{mol}$ (para $\mathrm{C}-\mathrm{H}$ activation), $16.7 \mathrm{kcal} /$ mol (meta $\mathrm{C}-\mathrm{H}$ activation) and 18.7 (ortho $\mathrm{C}-\mathrm{H}$ activation). Thus, the calculations suggest that the energetics of ethylbenzene dissociation and a second $\mathrm{C}-\mathrm{H}$ activation are of similar magnitude. As a benchmark, the energetics of ethylbenzene dissociation were compared with that for the charge-neutral complex $(\mathrm{dmpp}) \mathrm{Pt}(\mathrm{Ph})\left(\eta^{2}-C, C\right.$-ethylbenzene $) \quad[\mathrm{dmpp}=3,5$-dimethyl2-(2-pyridyl)pyrrolide], which exhibits less extensive formation of diethylbenzenes during catalytic hydrophenylation of ethylene. The barrier to ethylbenzene dissociation from (dmpp)Pt$(\mathrm{Ph})\left(\eta^{2}-C, C\right.$-ethylbenzene) was calculated to be only $0.6 \mathrm{kcal} /$ mol, and ethylbenzene dissociation from $\mathrm{TpRu}(\mathrm{CO})$ (ethylbenzene $)(\mathrm{Ph})$ is calculated to be exergonic by $8 \mathrm{kcal} / \mathrm{mol}$ (Scheme 19).

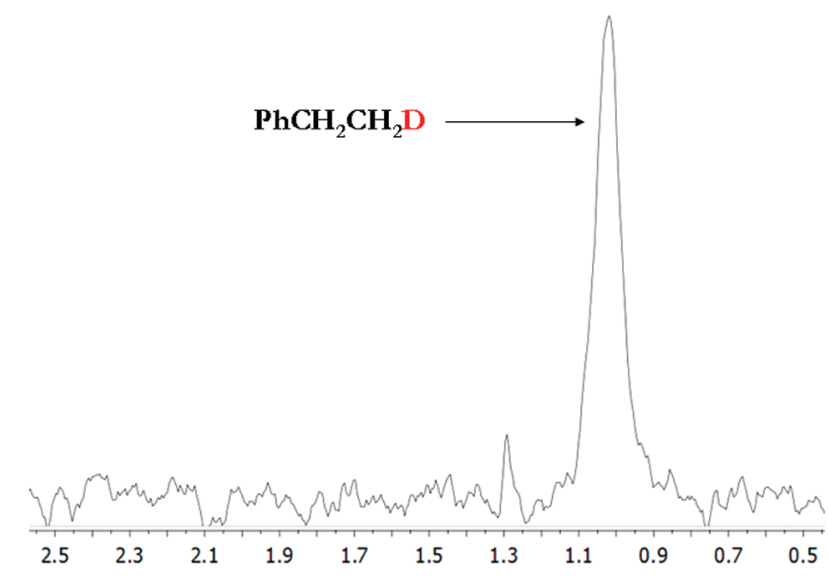

Figure 15. ${ }^{2} \mathrm{H}$ NMR spectrum for the product of thermolysis of 4 in $\mathrm{C}_{6} \mathrm{D}_{6}$, highlighting the resonance $(\delta=1.03 \mathrm{ppm})$ of the ethylbenzene isotopologues possessing an ethyl fragment with a terminal $-\mathrm{CH}_{2} \mathrm{D}$ group. Incorporation of deuterium into the benzylic position is not observed.

Scheme 19. Comparison of the Calculated $\Delta G(\mathrm{kcal} / \mathrm{mol}$; gas phase) for Ethylbenzene Dissociation from Several Reported Ethylene Hydroarylation Catalysts

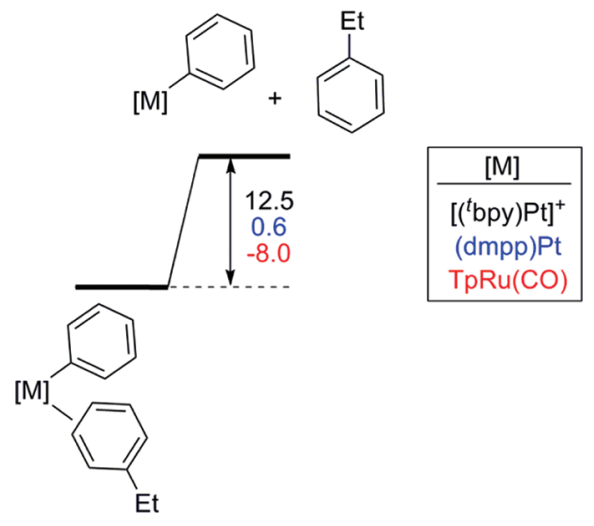

A striking observation is the regioselectivity for diethylbenzene formation as a function of aromatic substrate. For example, the ortho:meta:para $(o: m: p)$ selectivity for the production of diethylbenzenes from 1 with ethylene and benzene is 1:2.6:1.6 after $4 \mathrm{~h}$ (Table 1$)$. In contrast, for the reaction of ethylene with ethylbenzene under identical conditions, the $o: m: p$ selectivity is 1.0:34.8:24.0 (eq 7). Notably, the $m / p$ selectivity ratio is approximately the same as the reaction with benzene while the ratio of $o$ to $m / p$ changes dramatically. The different selectivity suggests distinct pathways for diethylbenzene formation from $\mathrm{C}_{2} \mathrm{H}_{4} / \mathrm{C}_{6} \mathrm{H}_{6}$ and $\mathrm{C}_{2} \mathrm{H}_{4}$ /ethylbenzene reactions (Scheme 20). For the reaction of ethylene and benzene, the formation of diethylbenzene is proposed to originate via benzene $\mathrm{C}-\mathrm{H}$ activation to give $\mathbf{A}$, followed by $\mathrm{sp}^{2} \mathrm{C}-\mathrm{H}$ activation of the coordinated ethylbenzene (Scheme 15). In this scenario, $\mathrm{Pt}$ (II) migrates from the methyl group of coordinated ethylbenzene ( $\mathbf{C}$ in Scheme 20) to an $\eta^{2}-C, C$ intermediate involving the ortho carbon (D in Scheme 20). If the rate of aromatic $\mathrm{C}-\mathrm{H}$ activation is competitive with migration around the phenyl ring, it is expected that ortho $\mathrm{C}-\mathrm{H}$ activation, ultimately resulting in 1,2-diethylbenzene, will be competitive. For the 
Scheme 20. Pathway for Diethylbenzene Formation from $\mathrm{C}_{6} \mathrm{H}_{6}$ and $\mathrm{C}_{2} \mathrm{H}_{4}$ Requires Pt to Interact with the 2-Position Carbon, Which Provides a Route for 1,2-Diethylbenzene Formation

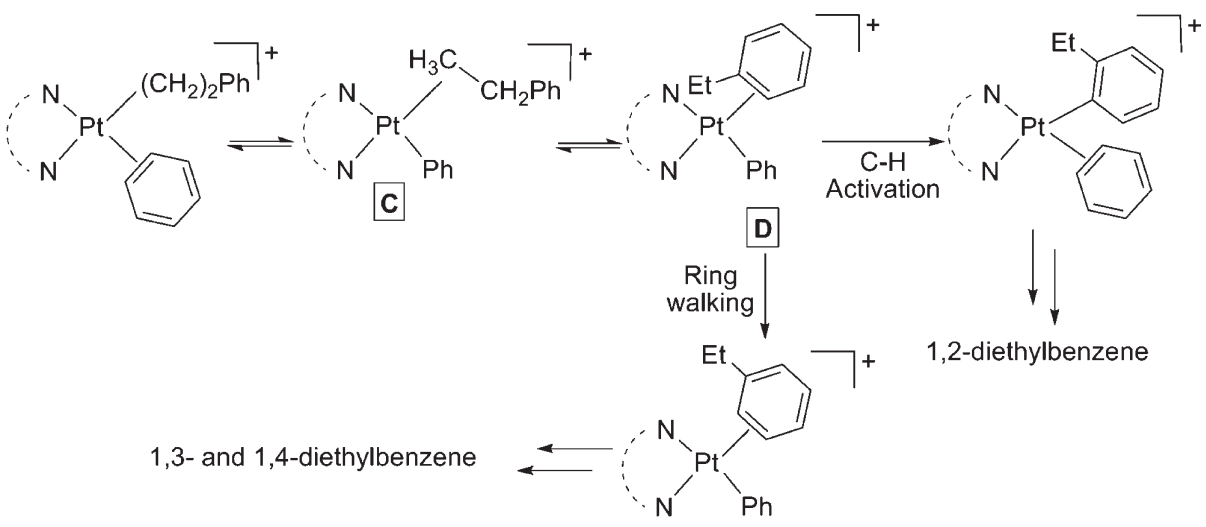

catalytic ethylation of toluene, the $\mathrm{Pt}(\mathrm{II})$ catalyst reported by Goldberg et al. provided an $o / m+p$ selectivity of 7:93 (the meta and para isomers could not be separated). ${ }^{21}$ is

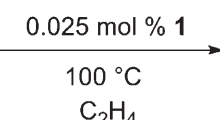<smiles>CCc1ccccc1CC</smiles><smiles>CCc1cccc(CC)c1</smiles><smiles>CCc1ccc(CC)cc1</smiles>

$o: m: p$ selectivity $=1: 34 \cdot 8: 24.0$
For the formation of diethylbenzenes from free ethylbenzene and ethylene, the regioselectivity is dictated by the coordination and $\mathrm{C}-\mathrm{H}$ activation of ethylbenzene. Here, free ethylbenzene likely coordinates to $\mathrm{Pt}(\mathrm{II})$ via an initial $\eta^{2}-C, C$ complex, possibly with a preferred orientation of the ethyl group away from the $\mathrm{Pt}$ (II) center in order to reduce steric interactions. Hence, the aromatic $\mathrm{C}-\mathrm{H}$ activation can occur without $\mathrm{Pt}(\mathrm{II})$ directly interacting with the ortho carbon, which contrasts with diethylbenzene formed from ethylene and benzene, since the proposed pathway requires $\mathrm{Pt}$ to interact with the carbon ortho to the ethyl group. This results in the decreased selectivity for meta and para over ortho for diethylbenzene formation from benzene and ethylene.

\section{SUMMARY AND CONCLUSIONS}

The cationic fragment $\left[\left({ }^{t} \mathrm{bpy}\right) \mathrm{Pt}(\mathrm{Ph})\right]^{+}$serves as a catalyst for the hydrophenylation of ethylene by a non-Friedel-Crafts pathway. One of the overarching goals of this work was a comparison of catalytic olefin hydroarylation using a late transition metal catalyst, traditionally considered electrophilic in character, with catalysts based on $\mathrm{d}^{6}$ systems that are considered more electronrich (e.g., $\mathrm{Ru}(\mathrm{II})$ and $\mathrm{Ir}(\mathrm{III})$ catalysts). On the basis of this study, the following salient points are emphasized:

(1) Experimental studies for the catalytic conversion of ethylene and benzene to ethylbenzene are consistent with a cycle that involves ethylene coordination and insertion followed by $\mathrm{Pt}$-mediated benzene $\mathrm{C}-\mathrm{H}$ activation with the latter step, or the $\mathrm{C}-\mathrm{H}$ coordination step, as the ratelimiting step. In addition, monitoring catalysis by ${ }^{1} \mathrm{H}$ NMR spectroscopy reveals that $\left[\left({ }^{t}\right.\right.$ bpy $) \mathrm{Pt}\left(\mathrm{CH}_{2} \mathrm{CH}_{2} \mathrm{Ph}\right)$ $\left.\left(\eta^{2}-\mathrm{C}_{2} \mathrm{H}_{4}\right)\right]^{+}$is likely the catalyst resting state. DFT calculations are consistent with these conclusions. Thus, despite studies that reveal alternative mechanisms for catalytic olefin hydroarylation initiated by $\mathrm{Pt}(\mathrm{II})$ systems, ${ }^{30,82}$ our results provide evidence that late transition metal systems can catalyze olefin hydroarylation by a pathway that involves olefin coordination, olefin insertion, and metal-mediated aromatic $\mathrm{C}-\mathrm{H}$ activation.

(2) In contrast to traditional Friedel-Crafts catalysts, starting with ethylbenzene, the $\left[\left({ }^{t} \mathrm{bpy}\right) \mathrm{Pt}(\mathrm{Ph})\right]^{+}$catalyst is highly selective for 1,3- and 1,4-diethylbenzene over 1,2diethylbenzene.

(3) The platinum catalysts related to $\left[\left({ }^{t} \mathrm{bpy}\right) \mathrm{Pt}(\mathrm{Ph})\right]^{+}$result in high yields under conditions in which ethylene is the limiting reagent. The catalyst also displays a tolerance toward exposure to aerobic conditions. The formation of vinyl arene via $\beta$-hydride elimination and olefin dissociation occurs only to a minor extent even though computational studies indicate that $\beta$-hydride elimination from $\left[\left({ }^{t} \text { bpy }\right) \mathrm{Pt}\left(\mathrm{CH}_{2} \mathrm{CH}_{2} \mathrm{Ph}\right)\right]^{+}$should have a low $\Delta G^{\ddagger}$. Thus, the lack of substantial styrene production may result from facile reinsertion relative to the rate of styrene dissociation.

(4) The competition between olefin insertion and olefin $\mathrm{C}-\mathrm{H}$ activation is a key parameter for olefin hydroarylation catalysts. Compared with $\mathrm{TpRu}(\mathrm{L})(\mathrm{NCMe}) \mathrm{Ph}$ systems, calculations (supported by experimental studies) suggest that the Pt catalysts have a larger $\Delta \Delta G^{\ddagger}$ that favors the desired catalysis.

(5) The formation of diethylbenzene products using $1-3$ as catalyst precursors is hypothesized to be a result of a second aromatic $\mathrm{C}-\mathrm{H}$ activation that competes with the dissociation of ethylbenzene. This is distinct from polyalkylation in Friedel-Crafts catalysis, which is thought to originate from enhanced rates of reaction of free alkyl arenes relative to the starting arene. ${ }^{3}$ The barrier to hydrocarbon dissociation using $\mathbf{1}$ is consistent with observations of other cationic, late transition metal systems. ${ }^{87,88}$ Also relevant here are data consistent with alkane intermediates involved in Pt(II) systems, ${ }^{53,89}$ and implications of barriers for hydrocarbon dissociation which facilitate the polyfunctionalization of methane, best studied in cases of $\mathrm{H} / \mathrm{D}$ exchange. ${ }^{54}$ While previous studies of $\mathrm{H} / \mathrm{D}$ exchange have implicated coordinated hydrocarbons as intermediates, ${ }^{46,90}$ to our knowledge this is a rare example of such an effect impacting the selectivity of a catalytic reaction, and it suggests an important 
consideration when designing catalysts for olefin hydroarylation using late transition metals. The present research implies that the cationic charge on [( $\left.{ }^{t} \mathrm{bpy}\right) \mathrm{Pt}-$ $(\mathrm{Ph})]^{+}$may play an important role in selectivity vis-à-vis mono- versus polyalkylated products, a notion that is consistent with the neutral catalyst (dmpp) Pt $\left(\mathrm{CH}_{2}\right.$ $\left.\mathrm{CH}_{2} \mathrm{Ph}\right)\left(\eta^{2}-\mathrm{C}_{2} \mathrm{H}_{4}\right)$ producing only small amounts of diethylbenzenes. ${ }^{21}$ This working hypothesis further hints at improved design strategies for olefin hydroarylation catalysts, e.g. via attenuation of the electrophilicity of the metal center with overall neutral catalysts.

\section{EXPERIMENTAL SECTION}

General Considerations. Unless otherwise noted, all synthetic procedures were performed under anaerobic conditions in a nitrogenfilled glovebox or by using standard Schlenk techniques. Glovebox purity was maintained by periodic nitrogen purges and was monitored by an oxygen analyzer $\left(\mathrm{O}_{2}<15 \mathrm{ppm}\right.$ for all reactions). Tetrahydrofuran and n-pentane were dried by distillation from sodium/benzophenone and $\mathrm{P}_{2} \mathrm{O}_{5}$, respectively. Diethyl ether and perfluoropyridine were distilled over $\mathrm{CaH}_{2}$. Methylene chloride and benzene were purified by passage through a column of activated alumina. Benzene- $d_{6}$, acetone- $d_{6}$, and $\mathrm{CD}_{2} \mathrm{Cl}_{2}$ were used as received and stored under a $\mathrm{N}_{2}$ atmosphere over $4 \AA$ molecular sieves. ${ }^{1} \mathrm{H}$ NMR spectra were recorded on a Varian Mercury 300 or $500 \mathrm{MHz}$ spectrometer. All ${ }^{1} \mathrm{H}$ spectra are referenced against residual proton signals of the deuterated solvents. ${ }^{19} \mathrm{~F} \mathrm{NMR}(282 \mathrm{MHz}$ operating frequency) spectra were obtained on a Varian $300 \mathrm{MHz}$ spectrometer and referenced against an external standard of hexafluorobenzene $(\delta=-164.9 \mathrm{ppm}) .{ }^{2} \mathrm{H} \mathrm{NMR}$ (77 MHz operating frequency) spectra were obtained on a Varian Mercury $500 \mathrm{MHz}$ spectrometer. GC/MS was performed using a Shimadzu GCMS-QP2010 Plus system with a $30 \mathrm{~mm} \times 0.25 \mathrm{~mm}$ SHRXI-5MS column with $0.25 \mathrm{~mm}$ film thickness using negative chemical ionization $(\mathrm{NCI})$, which also allows for simulated electron impact (SEI) ionization. Ethylene (99.5\%) was purchased in a gas cylinder from GTS-Welco and used as received. All other reagents were used as purchased from commercial sources. The preparation, isolation, and characterization of $\left[\mathrm{H}\left(\mathrm{Et}_{2} \mathrm{O}\right)_{2}\right]\left[\mathrm{BAr}_{4}{ }_{4}\right]^{91}$ $\left({ }^{t} \mathrm{bpy}\right) \mathrm{Pt}(\mathrm{Ph})_{2},{ }^{44}$ and $\mathrm{PhLi}-d_{5}{ }^{92}$ have been previously reported.

Computational Methods. All computations were performed using $2,2^{\prime}$-bipyridyl as a model ligand for $4,4^{\prime}$-ditertbutyl-2,2' $2^{\prime}$-bipyridyl. The DFT calculations were carried out using the Gaussian 03 software package. All optimizations were done with B3LYP ${ }^{93-95}$ using the Stevens valence basis sets, CEP-31G (5d, 7f), ${ }^{96-99}$ and pseudopotentials. Extra d polarization basis functions were added to the main group elements using values taken from the 6-31G(d) all-electron basis sets. Given that the majority of the species in this study are cationic, solvent effects were assessed for a more accurate description of energetics. CPCM, Conductor-like Polarized Continuum Method, ${ }^{100-103}$ was used with both benzene and THF as the solvents selected to run the calculations. Little qualitative difference in the various steps was seen in the various solvent media. Reported free energies were determined at 298.15 K and $1 \mathrm{~atm}$ using unscaled B3LYP frequencies. Unless stated otherwise, the calculated free energies are those modeled in THF solvent.

$\left[\left({ }^{t} \mathrm{bpy}\right) \mathrm{Pt}(\mathrm{Ph})(\mathrm{THF})\right]\left[\mathrm{BAr}{ }_{4}\right]$ (1). To a cooled solution of ( $\left.{ }^{t} \mathrm{bpy}\right) \mathrm{Pt}-$ $(\mathrm{Ph})_{2}(0.095 \mathrm{~g}, 0.15 \mathrm{mmol})$ in THF $\left(\sim 20 \mathrm{~mL},-60^{\circ} \mathrm{C}\right)$, [ $\left.\mathrm{H}\left(\mathrm{Et}_{2} \mathrm{O}\right)_{2}\right]$ [BAr ${ }_{4}{ }_{4}$ ( $\left.0.16 \mathrm{~g}, 0.15 \mathrm{mmol}\right)$ in THF $\left(\sim 15 \mathrm{~mL},-60{ }^{\circ} \mathrm{C}\right)$ was added. After the addition, the volatiles were removed in vacuo. The crude solid was treated with $n$-pentane $(\sim 2 \mathrm{~mL})$, which was subsequently removed under vacuum to afford a fluffy, yellow powder. The resulting product was then dried in vacuo $(0.21 \mathrm{~g}, 93 \%) .{ }^{1} \mathrm{H} \mathrm{NMR}\left(300 \mathrm{MHz}, \mathrm{CD}_{2} \mathrm{Cl}_{2}\right) \delta$ $8.36\left(\mathrm{~d}, 1 \mathrm{H},{ }^{3} \mathrm{~J}_{\mathrm{HH}}=6 \mathrm{~Hz}, \mathrm{H}^{6}{ }^{-} \mathrm{bpy}\right), 8.14\left(\mathrm{~d}, 1 \mathrm{H},{ }^{3} J_{\mathrm{HH}}=6 \mathrm{~Hz}, \mathrm{H}^{6}{ }_{-}{ }_{\mathrm{b} p y}\right)$, $8.09\left(\mathrm{~d}, 1 \mathrm{H},{ }^{4} J_{\mathrm{HH}}=2 \mathrm{~Hz}, \mathrm{H}^{3}{ }^{-}{ }^{t} \mathrm{bpy}\right), 7.97\left(\mathrm{~d}, 1 \mathrm{H},{ }^{4} J_{\mathrm{HH}}=2 \mathrm{~Hz}, \mathrm{H}^{3}{ }^{t} \mathrm{bpy}\right)$, $7.78\left(\mathrm{dd}, 1 \mathrm{H},{ }^{3} \mathrm{~J}_{\mathrm{HH}}=6 \mathrm{~Hz},{ }^{4} \mathrm{~J}_{\mathrm{HH}}=2 \mathrm{~Hz}, \mathrm{H}^{5}{ }^{t} \mathrm{bpy}\right), 7.71($ br s, $8 \mathrm{H}$, $\left.H_{o}\left(\mathrm{Ar}^{\prime}\right)\right), 7.55\left[\mathrm{br} \mathrm{s}, 4 \mathrm{H} H_{p}\left(\mathrm{Ar}^{\prime}\right)\right], 7.46\left[\mathrm{~d}, 1 \mathrm{H},{ }^{3} J_{\mathrm{HH}}=7 \mathrm{~Hz}, \mathrm{H}_{o}(\mathrm{Ph})\right]$, $7.27\left(\mathrm{dd}, 1 \mathrm{H},{ }^{3} \mathrm{~J}_{\mathrm{HH}}=6 \mathrm{~Hz},{ }^{4} J_{\mathrm{HH}}=2 \mathrm{~Hz}, \mathrm{H}^{5}{ }^{t} \mathrm{bpy}\right), 7.16[\mathrm{~m}, 2 \mathrm{H}$, $\left.\mathrm{H}_{m}(\mathrm{Ph})\right], 7.06\left[\mathrm{~m}, 1 \mathrm{H}, \mathrm{H}_{p}(\mathrm{Ph})\right], 4.14$ (br m, 4H, $\mathrm{H}^{2}$-THF), 1.86 (br m, $4 \mathrm{H}, \mathrm{H}^{3}$-THF), 1.46 (s, 9H, tert-butyl ${ }^{t}$ bpy), 1.38 (s, 9H, tert-butyl ${ }^{t}$ bpy). ${ }^{1} \mathrm{H}$ NMR (tetrahydrofuran- $\left.d_{8}\right) \delta 8.54\left(\mathrm{~d}, 1 \mathrm{H},{ }^{3} \mathrm{~J}_{\mathrm{HH}}=6 \mathrm{~Hz}, \mathrm{H}^{6}{ }_{-}{ }_{\mathrm{b} p y}\right)$, 8.51 (s, $1 \mathrm{H}, \mathrm{H}^{3}$ - $^{t}$ bpy), 8.39 (s, $\left.1 \mathrm{H}, \mathrm{H}^{3}{ }^{\mathrm{t}} \mathrm{bpy}\right), 8.17\left(\mathrm{~d}, 1 \mathrm{H},{ }^{3} \mathrm{~J}_{\mathrm{HH}}=6 \mathrm{~Hz}\right.$, $\mathrm{H}^{6}{ }^{t}$ bpy), 7.89 (d, $\left.1 \mathrm{H},{ }^{3} J_{\mathrm{HH}}=6 \mathrm{~Hz}, \mathrm{H}^{5}{ }^{t} \mathrm{bpy}\right), 7.80\left[\mathrm{br} \mathrm{s}, 9 \mathrm{H}, H_{o}\left(\mathrm{Ar}^{\prime}\right)\right.$ and $\mathrm{H}^{5}{ }^{t}$ bpy ], $7.58\left[\mathrm{br} \mathrm{s}, 4 \mathrm{H}, \mathrm{H}_{p}\left(\mathrm{Ar}^{\prime}\right)\right], 7.50\left(\mathrm{~d}, 1 \mathrm{H},{ }^{3} \mathrm{~J}_{\mathrm{HH}}=7 \mathrm{~Hz}\right.$, $\left.\mathrm{H}_{o}(\mathrm{Ph})\right], 7.13\left[\mathrm{~m}, 2 \mathrm{H}, H_{m}(\mathrm{Ph}), 7.03\left(\mathrm{~m}, 1 \mathrm{H}, \mathrm{H}_{p}(\mathrm{Ph})\right], 1.47(\mathrm{~s}, 9 \mathrm{H}\right.$, tertbutyl ${ }^{t}$ bpy), 1.39 (s, $9 \mathrm{H}$, tert-butyl $\left.{ }^{t} \mathrm{bpy}\right)$. Resonances due to coordinated THF were not observed due to rapid exchange with THF- $d_{8} \cdot{ }^{13} \mathrm{C}$ NMR (75 MHz, tetrahydrofuran- $d_{8}$ ) $\delta 166.5,166.3,158.6,154.8,153.9,147.2$, $140.8,137.5,136.8,128.6,125.4,121.7,121.2$ ('bpy and $\mathrm{Ph}$ aromatic), 36.6 (tert-butyl, quaternary, ${ }^{t} \mathrm{bpy}$ ), 36.5 (tert-butyl, quaternary, ${ }^{t} \mathrm{bpy}$ ), 30.0 (tert-butyl- $\mathrm{CH}_{3},{ }^{t} \mathrm{bpy}$ ), 29.8 (tert-butyl- $\left.\mathrm{CH}_{3},{ }^{t} \mathrm{bpy}\right) ; 162.6$ (q, $\mathrm{Ar}^{\prime}$, $\left.{ }^{1} J_{\mathrm{B}-\mathrm{C} \text { ipso }}=50 \mathrm{~Hz}\right), 135.4\left(\mathrm{Ar}^{\prime}\right), 129.9\left(\mathrm{q}, m-\mathrm{Ar}^{\prime},{ }^{2} J_{\mathrm{C}-\mathrm{F}}=32 \mathrm{~Hz}\right), 127.1$ $\left(\mathrm{q}, \mathrm{CF}_{3}-\mathrm{Ar}^{\prime},{ }^{1} J_{\mathrm{C}-\mathrm{F}}=272 \mathrm{~Hz}\right), 118.0\left(\mathrm{Ar}^{\prime}\right) .{ }^{19} \mathrm{~F}$ NMR $(282 \mathrm{MHz}$, $\left.\mathrm{CD}_{2} \mathrm{Cl}_{2}\right) \delta-62.2\left(\mathrm{~s}, \mathrm{CF}_{3}-\mathrm{Ar}^{\prime}\right)$. Anal. Calcd for $\mathrm{PtBON}_{2} \mathrm{~F}_{24} \mathrm{C}_{60} \mathrm{H}_{49}(\%)$ : C 48.82, H 3.35, N 1.90; found: C 48.27, H 3.13, N 2.12.

$\left[\left({ }^{t} \mathrm{bpy}\right) \mathrm{Pt}\left(\mathrm{Ph}-d_{5}\right)(\mathrm{THF})\right]\left[\mathrm{BAr}{ }_{4}\right]\left(1-d_{5}\right)$. This complex was synthesized by the procedure used for $\mathbf{1}$. In the preparation of the initial starting material, $\mathrm{PhLi}$ was substituted with $\mathrm{PhLi}-d_{5}$ to produce $\left({ }^{t} \mathrm{bpy}\right) \mathrm{Pt}(\mathrm{Ph}-$ $\left.d_{5}\right)_{2} \cdot{ }^{1} \mathrm{H}$ and ${ }^{13} \mathrm{C}$ NMR spectra are consistent with the all protio analogue minus the resonances for the phenyl ring in the ${ }^{1} \mathrm{H}$ NMR spectrum.

$\left[\left({ }^{t} \mathrm{bpy}\right) \mathrm{Pt}\left(\mathrm{NC}_{5} \mathrm{~F}_{5}\right)(\mathrm{Ph})\right]\left[\mathrm{BAr}_{4}^{\prime}\right](2)$. To a cooled solution of ( $\left.{ }^{t} \mathrm{bpy}\right)$ $\mathrm{Pt}(\mathrm{Ph})_{2}(0.14 \mathrm{~g}, 0.22 \mathrm{mmol})$ in THF $\left(\sim 20 \mathrm{~mL},-60^{\circ} \mathrm{C}\right),\left[\mathrm{H}\left(\mathrm{Et}_{2} \mathrm{O}\right)_{2}\right]$ [BAr ${ }_{4}^{\prime}$ ] $(0.26 \mathrm{~g}, 0.22 \mathrm{mmol})$ in THF $\left(\sim 15 \mathrm{~mL},-60^{\circ} \mathrm{C}\right)$ was added. After the addition, the volatiles were removed in vacuo. The crude solid was then reconstituted in perfluoropyridine $(\sim 5 \mathrm{~mL})$. The solution was stirred at room temperature for $36 \mathrm{~h}$. The volatiles were then removed. The crude solid was treated with $n$-pentane $(\sim 2 \mathrm{~mL})$, which was subsequently removed under vacuum to afford a fluffy, orange powder. The resulting product was then dried in vacuo $(0.33 \mathrm{~g}, 96 \%) .{ }^{1} \mathrm{H}$ NMR $\left(\mathrm{NC}_{5} \mathrm{~F}_{5}\right.$, acetone- $d_{6}$ insert $) \delta 7.36\left(\mathrm{~s}, 1 \mathrm{H}, \mathrm{H}^{3}\right.$ - $\left.{ }^{\mathrm{bppy}}\right), 7.30(\mathrm{~s}, 1 \mathrm{H}$, $\mathrm{H}^{3}{ }^{t}$ bpy), $7.06\left(\mathrm{~d}, 1 \mathrm{H},{ }^{3} J_{\mathrm{HH}}=6 \mathrm{~Hz}, \mathrm{H}^{6}{ }^{t}\right.$ bpy), $6.92\left(\mathrm{~d}, 1 \mathrm{H},{ }^{3} \mathrm{~J}_{\mathrm{HH}}=\right.$ $6 \mathrm{~Hz}, \mathrm{H}^{6}$ - $\left.{ }^{\mathrm{bppy}}\right), 6.62\left[\mathrm{brs}, 10 \mathrm{H}, \mathrm{H}_{o}\left(\mathrm{Ar}^{\prime}\right)\right.$ and $\left.H_{o}(\mathrm{Ph})\right], 6.56\left(\mathrm{~d}, 1 \mathrm{H},{ }^{3} \mathrm{~J}_{\mathrm{HH}}=\right.$ $\left.6 \mathrm{~Hz}, \mathrm{H}^{5}{ }^{t} \mathrm{bpy}\right), 6.18$ [br s, $5 \mathrm{H}, H_{p}\left(\mathrm{Ar}^{\prime}\right)$ and $\mathrm{H}^{5}{ }^{t} \mathrm{bpy}$ ], $5.63(\mathrm{t}, 2 \mathrm{H}$, $\left.{ }^{3} J_{\mathrm{HH}}=7 \mathrm{~Hz}, \mathrm{H}_{m}(\mathrm{Ph})\right], 5.39\left[\mathrm{t}, 1 \mathrm{H},{ }^{3} J_{\mathrm{HH}}=7 \mathrm{~Hz}, \mathrm{H}_{p}(\mathrm{Ph})\right], 0.36(\mathrm{~s}, 9 \mathrm{H}$, tert-butyl ${ }^{t}$ bpy), 0.29 (s, 9H, tert-butyl ${ }^{t}$ bpy $) .{ }^{13} \mathrm{C} \mathrm{NMR}\left(75 \mathrm{MHz}, \mathrm{NC}_{5} \mathrm{~F}_{5}\right.$ with acetone- $d_{6}$ insert) $\delta 166.3,156.0,153.2,150.6,145.9,126.3,124.3$, 123.9, 122.9, 119.1 ('bpy and $\mathrm{Ph}$ aromatic), 34.6 (tert-butyl, quaternary, ${ }^{t}$ bpy, coincidental overlap), 27.7 (tert-butyl- $\mathrm{CH}_{3},{ }^{t}$ bpy), 27.6 (tert-butyl$\left.\mathrm{CH}_{3},{ }^{t} \mathrm{bpy}\right) ; 160.9\left(\mathrm{q}, \mathrm{Ar}^{\prime},{ }^{1} J_{\mathrm{B}-\mathrm{Cipso}}=50 \mathrm{~Hz}\right), 127.6\left(\mathrm{q}, m-\mathrm{Ar}^{\prime},{ }^{2} J_{\mathrm{C}-\mathrm{F}}=31\right.$ $\mathrm{Hz}), 123.4\left(\mathrm{q}, \mathrm{CF}_{3}-\mathrm{Ar}^{\prime},{ }^{1} J_{\mathrm{C}-\mathrm{F}}=272 \mathrm{~Hz}\right), 115.5\left(\mathrm{Ar}^{\prime}\right)$. Resonances for coordinated perfluoropyridine were not observed due to ligand exchange and resulting time averaged signals at room temperature. Remaining five ${ }^{t} \mathrm{bpy}, \mathrm{Ph}$, and $\mathrm{Ar}^{\prime}$ aromatic resonances are obscured due to broad $\mathrm{NC}_{5} \mathrm{~F}_{5}$ resonances or coincidental overlap. ${ }^{19} \mathrm{~F}$ NMR (282 $\left.\mathrm{MHz}, \mathrm{CD}_{2} \mathrm{Cl}_{2}\right) \delta-61.2\left(\mathrm{~s}, 24 \mathrm{~F}, \mathrm{CF}_{3}-\mathrm{Ar}^{\prime}\right),-74.3\left(\mathrm{~m}, 2 \mathrm{~F},{ }^{3} J_{\mathrm{Pt}-\mathrm{F}}=316\right.$ $\mathrm{Hz}$ (Pt satellites), o-NC $F_{5}$ ), $-118.9\left(\mathrm{~m}, 1 \mathrm{~F}, p-\mathrm{NC}_{5} F_{5}\right),-154.2(\mathrm{~m}, 2 \mathrm{~F}$, $\left.m-\mathrm{NC}_{5} F_{5}\right)$. Anal. Calcd for $\mathrm{PtBN}_{3} \mathrm{~F}_{29} \mathrm{C}_{61} \mathrm{H}_{41}$ (\%): C 46.58, H 2.63, N 2.67; found: C 46.54, H 2.65, N 2.20.

$\left[\left({ }^{t} \mathrm{bpy}\right) \mathrm{Pt}(\mathrm{NCMe})(\mathrm{Ph})\right]\left[\mathrm{BAr}_{4}{ }_{4}\right]$ (3). To a cooled solution of ( ${ }^{t}$ bpy $) \mathrm{Pt}(\mathrm{Ph})_{2}(0.090 \mathrm{~g}, 0.15 \mathrm{mmol})$ in THF $\left(\sim 20 \mathrm{~mL},-60{ }^{\circ} \mathrm{C}\right)$ was added $\left[\mathrm{H}\left(\mathrm{Et}_{2} \mathrm{O}\right)_{2}\right]\left[\mathrm{BAr}_{4}^{\prime}\right](0.16 \mathrm{~g}, 0.15 \mathrm{mmol})$ in THF $(\sim 15 \mathrm{~mL}$, $\left.-60{ }^{\circ} \mathrm{C}\right)$. After the addition, the volatiles were removed in vacuo. The crude solid was then reconstituted in acetonitrile $(\sim 5 \mathrm{~mL})$. The solution was stirred at room temperature for $15 \mathrm{~min}$. The volatiles were then removed. The crude solid was treated with $n$-pentane $(\sim 2 \mathrm{~mL})$, which was subsequently removed under vacuum to afford a fluffy, yellow powder. The resulting product was then dried in vacuo $(0.20 \mathrm{~g}, 94 \%)$. ${ }^{1} \mathrm{H}$ NMR (acetone- $\left.d_{6}\right) \delta 9.02\left(\mathrm{~d}, 1 \mathrm{H},{ }^{3} J_{\mathrm{HH}}=5.8 \mathrm{~Hz}, \mathrm{H}^{6}{ }^{-}{ }^{t}\right.$ bpy), 8.80 
$\left(\mathrm{d}, 1 \mathrm{H},{ }^{4} J_{\mathrm{HH}}=1.9 \mathrm{~Hz}, \mathrm{H}^{3}{ }^{t}{ }^{\mathrm{b}} \mathrm{bpy}\right), 8.73\left(\mathrm{~d}, 1 \mathrm{H},{ }^{4} J_{\mathrm{HH}}=2.1 \mathrm{~Hz}, \mathrm{H}^{3}{ }^{t} \mathrm{bpy}\right)$, $8.25\left(\mathrm{~d}, 1 \mathrm{H},{ }^{3} J_{\mathrm{HH}}=6.3 \mathrm{~Hz}, \mathrm{H}^{6}{ }^{-}{ }_{\mathrm{bppy}}\right), 7.93\left(\mathrm{dd}, 1 \mathrm{H},{ }^{3} \mathrm{~J}_{\mathrm{HH}}=5.8,{ }^{4} \mathrm{~J}_{\mathrm{HH}}=1.9\right.$ $\left.\mathrm{Hz}, \mathrm{H}^{5}{ }^{t} \mathrm{bpy}\right), 7.80\left(\mathrm{br} \mathrm{s}, 8 \mathrm{H}, \mathrm{H}_{\mathrm{o}}\left(\mathrm{Ar}^{\prime}\right)\right), 7.72\left(\mathrm{dd}, 1 \mathrm{H},{ }^{3} J_{\mathrm{HH}}=6.3,{ }^{4} J_{\mathrm{HH}}=\right.$ 2.1, $\left.\mathrm{H}^{5}{ }^{\mathrm{t}} \mathrm{bpy}\right), 7.68$ (br s, 4H, $\left.H_{p}\left(\mathrm{Ar}^{\prime}\right)\right), 7.39\left(\mathrm{~m}, 2 \mathrm{H}, H_{o}(\mathrm{Ph})\right), 7.10(\mathrm{~m}$, $3 \mathrm{H}, H_{m}(\mathrm{Ph})$ and $\left.H_{p}(\mathrm{Ph})\right), 2.81(\mathrm{~s}, 3 \mathrm{H}, \mathrm{NCMe}), 1.48$ (s, 9H, tert-butyl ${ }^{t}$ bpy), 1.43 (s, 9H, tert-butyl ${ }^{t}$ bpy). ${ }^{13} \mathrm{C}$ NMR $\left(75 \mathrm{MHz}\right.$, acetone- $\left.d_{6}\right) \delta$ 167.0, 166.9, 158.8, 155.2, 152.4, 149.7, 137.5, 128.9, 126.1, 125.9, 125.5, 122.8, 122.2, 120.9 ( ${ }^{t}$ bpy and $\mathrm{Ph}$ aromatic), 69.5 (tert-butyl, quaternary, ${ }^{t}$ bpy), 68.2 (tert-butyl, quaternary, ${ }^{t}$ bpy), 37.0 (tert-butyl- $\mathrm{CH}_{3}$, coincidental overlap), $4.2\left(\mathrm{NCMe}, \mathrm{CH}_{3}\right) ; 162.8\left(\mathrm{q}, \mathrm{Ar}^{\prime},{ }^{1} \mathrm{~J}_{\mathrm{B}-\mathrm{Cipso}}=50 \mathrm{~Hz}\right)$, $135.7\left(\mathrm{Ar}^{\prime}\right), 130.2\left(\mathrm{q}, \mathrm{m}-\mathrm{Ar}^{\prime},{ }^{2} J_{\mathrm{C}-\mathrm{F}}=31 \mathrm{~Hz}\right), 125.5\left(\mathrm{q}, \mathrm{CF}_{3}-\mathrm{Ar}^{\prime},{ }^{1} J_{\mathrm{C}-\mathrm{F}}=\right.$ $272 \mathrm{~Hz}), 118.6\left(\mathrm{Ar}^{\prime}\right) .{ }^{19} \mathrm{~F}$ NMR $\left(282 \mathrm{MHz}\right.$, acetone- $\left.d_{6}\right) \delta-60.6$ (s, $\mathrm{CF}_{3}-\mathrm{Ar}^{\prime}$ ). Anal. Calcd for $\mathrm{PtBN}_{3} \mathrm{~F}_{24} \mathrm{C}_{58} \mathrm{H}_{44}$ (\%): C 48.21, H 3.08, N 2.91; found: C 48.43, H 3.05, N 3.03.

$\left[\left({ }^{t} \mathrm{bpy}\right) \mathrm{Pt}\left(\mathrm{CH}_{2} \mathrm{CH}_{2} \mathrm{Ph}\right)\left(\eta^{2}-\mathrm{C}_{2} \mathrm{H}_{4}\right)\right]\left[\mathrm{BAr}_{4}{ }_{4}\right](4)$. Complex $1(0.033$ g, $0.019 \mathrm{mmol})$ was dissolved in dichloromethane $(\sim 5 \mathrm{~mL})$. The reaction mixture was transferred to a stainless steel pressure reactor and pressurized with ethylene $(0.3 \mathrm{MPa})$ for $16 \mathrm{~h}$. The volatiles were removed and pentane $(\sim 2 \mathrm{~mL})$ was added to the crude solid. The pentane was removed under vacuum to afford an orange solid. The solid was collected and dried in vacuo $(0.027 \mathrm{~g}, 97 \%) .{ }^{1} \mathrm{H}$ NMR $\left(\mathrm{CD}_{2} \mathrm{Cl}_{2}\right) \delta$ $8.67\left(\mathrm{~d}, 1 \mathrm{H},{ }^{3} \mathrm{~J}_{\mathrm{HH}}=6 \mathrm{~Hz}, \mathrm{H}^{6}{ }^{t} \mathrm{bpy}\right), 8.21$ (s, $\left.1 \mathrm{H}, \mathrm{H}^{3}{ }^{\mathrm{t}} \mathrm{bpy}\right), 8.16(\mathrm{~s}, 1 \mathrm{H}$, $\mathrm{H}^{3}{ }^{t}$ bpy), 7.93 (d, $1 \mathrm{H},{ }^{3} \mathrm{~J}_{\mathrm{HH}}=6 \mathrm{~Hz}, \mathrm{H}^{6}{ }^{t}$ bpy), $7.79\left(\mathrm{~d}, 1 \mathrm{H},{ }^{3} J_{\mathrm{HH}}=6 \mathrm{~Hz}\right.$, $\mathrm{H}^{5}{ }^{t}$ bpy $), 7.72\left[\mathrm{br} \mathrm{s}, 9 \mathrm{H}, \mathrm{H}_{o}\left(\mathrm{Ar}^{\prime}\right)\right.$ and $\mathrm{H}^{5}{ }^{t}$ bpy $], 7.55\left[\mathrm{br} \mathrm{s}, 4 \mathrm{H}, \mathrm{H}_{p}\left(\mathrm{Ar}^{\prime}\right)\right.$ ], $7.28-7.12(\mathrm{~m}, 5 \mathrm{H}, \mathrm{Ph}), 4.14$ (br s with doublet $(\sim 33 \%)$ due to ${ }^{2} J_{\mathrm{Pt}-\mathrm{H}}$, $\left.4 \mathrm{H},{ }^{2} J_{\mathrm{Pt}-\mathrm{H}}=69 \mathrm{~Hz}, \mathrm{C}_{2} \mathrm{H}_{4}\right), 2.70\left(\mathrm{t}, 2 \mathrm{H},{ }^{3} \mathrm{~J}_{\mathrm{HH}}=8 \mathrm{~Hz}, \mathrm{Pt}_{-} \mathrm{CH}_{2} \mathrm{CH}_{2} \mathrm{Ph}\right)$, 1.48 and 1.43 (overlapping resonances, $20 \mathrm{H}$, tert-butyl tbpy and $\left.\mathrm{PtCH}_{2} \mathrm{CH}_{2} \mathrm{Ph}\right) .{ }^{13} \mathrm{C}$ NMR $\left(75 \mathrm{MHz}, \mathrm{CD}_{2} \mathrm{Cl}_{2}\right) \delta 169.4,167.0,157.7$, 154.5, 148.1, 145.5, 144.0, 129.2, 126.7, 126.5, 125.8, 121.0, 120.9 ( ${ }^{t}$ bpy and $\mathrm{Ph}$ aromatic), $70.2\left(\mathrm{C}_{2} \mathrm{H}_{4}\right), 37.7\left(\mathrm{PtCH}_{2} \mathrm{CH}_{2} \mathrm{Ph},{ }^{2} J_{\mathrm{Pt}-\mathrm{C}}=28 \mathrm{~Hz}, \mathrm{Pt}\right.$ satellites), 36.9 (tert-butyl, quaternary, ${ }^{t}$ bpy), 36.6 (tert-butyl, quaternary, tbpy), 30.3 (tert-butyl- $\mathrm{CH}_{3}$, bpy, coincidental overlap), $17.0\left(\mathrm{PtCH}_{2^{-}}\right.$ $\mathrm{CH}_{2} \mathrm{Ph},{ }^{1} J_{\mathrm{Pt}-\mathrm{C}}=674 \mathrm{~Hz}, \mathrm{Pt}$ satellites $) ; 162.3\left(\mathrm{q}, \mathrm{Ar}^{\prime},{ }^{1} J_{\mathrm{B}-\text { Cipso }}=49 \mathrm{~Hz}\right)$, $135.4\left(\mathrm{Ar}^{\prime}\right), 129.5\left(\mathrm{q}, m-\mathrm{Ar}^{\prime},{ }^{2} J_{\mathrm{C}-\mathrm{F}}=32 \mathrm{~Hz}\right), 125.2\left(\mathrm{q}, \mathrm{Ar}^{\prime},{ }^{2} J_{\mathrm{C}-\mathrm{F}}=272\right.$ $\mathrm{Hz}), 118.1\left(\mathrm{Ar}^{\prime}\right)$. Remaining three ${ }^{t} \mathrm{bpy}$ and $\mathrm{Ph}$ aromatic resonances are obscured due to broadening or coincidental overlap. ${ }^{19} \mathrm{~F} \mathrm{NMR}(282 \mathrm{MHz}$, $\left.\mathrm{CD}_{2} \mathrm{Cl}_{2}\right) \delta-63.1\left(\mathrm{~s}, \mathrm{CF}_{3}-\mathrm{Ar}^{\prime}\right)$. Anal. Calcd for $\mathrm{PtBN}_{2} \mathrm{~F}_{24} \mathrm{C}_{60} \mathrm{H}_{49}$ (\%): C 49.36, H 3.39, N 1.92; found: C 49.28, H 3.27, N 1.89.

$\left[\left({ }^{t}\right.\right.$ bpy $\left.) \mathrm{Pt}\left(\mathrm{CH}_{2} \mathrm{CH}_{2} \mathrm{Ph}-d_{5}\right)\left(\eta^{2}-\mathrm{C}_{2} \mathrm{H}_{4}\right)\right]\left[\mathrm{BAr}_{4}{ }_{4}\right]\left(4-d_{5}\right)$. This complex was synthesized by the procedure used for 4 . In the preparation of the initial starting material, $\mathrm{PhLi}$ was substituted with $\mathrm{PhLi}-d_{5}$ to produce ( ${ }^{t}$ bpy) $\mathrm{Pt}\left(\mathrm{Ph}-d_{5}\right)_{2} .{ }^{1} \mathrm{H}$ and ${ }^{13} \mathrm{C}$ NMR spectra were consistent with the spectra of the all-protio analogue minus the resonances for the phenyl ring in the ${ }^{1} \mathrm{H}$ NMR spectrum.

[( ${ }^{t}$ bpy) Pt(Et)(NCMe)][BAr' $\left.{ }_{4}\right]$ (10). Method A: Complex 4 (0.060 g, $0.040 \mathrm{mmol})$ was dissolved in nitromethane- $d_{3}(0.4 \mathrm{~mL})$ and transferred to a high pressure NMR tube. The NMR tube was then degassed, pressurized with ethylene $(0.3 \mathrm{MPa})$, and heated at $80^{\circ} \mathrm{C}$ for $16 \mathrm{~h}$. To the solution was added $\mathrm{NCMe}(200 \mu \mathrm{L})$. After $2 \mathrm{~h}$, the solution was filtered through Celite using dichloromethane. The volatiles were removed from the filtrate in vacuo, and the resulting solid was collected $(0.039 \mathrm{~g}, 70 \%)$. The identity of the product was confirmed by comparison to a sample prepared by Method B. Method B: To a cooled solution of ( $\left.{ }^{t} \mathrm{bpy}\right) \mathrm{Pt}(\mathrm{Et})_{2}$ $(0.017 \mathrm{~g}, 0.030 \mathrm{mmol})$ in THF $\left(\sim 15 \mathrm{~mL},-60{ }^{\circ} \mathrm{C}\right),\left[\mathrm{H}\left(\mathrm{Et}_{2} \mathrm{O}\right)_{2}\right]\left[\mathrm{BAr}_{4}^{\prime}\right]$ $(0.033 \mathrm{~g}, 0.030 \mathrm{mmol})$ in THF $\left(\sim 5 \mathrm{~mL},-60{ }^{\circ} \mathrm{C}\right)$ was added. After the addition, the solution immediately changed from red-orange to pale yellow. The solvent volume was reduced by $\sim 50 \%$ under vacuum. Acetonitrile $(1 \mathrm{~mL})$ was added. All volatiles were removed in vacuo. The crude solid was treated with $n$-pentane $(\sim 1 \mathrm{~mL})$, which was subsequently removed under vacuum to afford a fluffy, yellow powder. The resulting product was dried in vacuo $(0.040 \mathrm{~g}, 92 \%) .{ }^{1} \mathrm{H}$ NMR $\left(\mathrm{CD}_{2} \mathrm{Cl}_{2}\right) \delta 8.79\left(\mathrm{~d}, 1 \mathrm{H},{ }^{3} \mathrm{~J}_{\mathrm{HH}}=6 \mathrm{~Hz}\right.$, $\mathrm{H}^{6}{ }^{\mathrm{t}}$ bpy), $8.57\left(\mathrm{~d}, 1 \mathrm{H},{ }^{3} \mathrm{~J}_{\mathrm{HH}}=6 \mathrm{~Hz}, \mathrm{H}^{6}{ }^{-}{ }^{\mathrm{b} p p y}\right), 8.10\left(\mathrm{~d}, 1 \mathrm{H},{ }^{4} \mathrm{~J}_{\mathrm{HH}}=2 \mathrm{~Hz}\right.$, $\left.\mathrm{H}^{3}{ }^{\mathrm{t}} \mathrm{bppy}\right), 8.07\left(\mathrm{~d}, 1 \mathrm{H},{ }^{4} \mathrm{~J}_{\mathrm{HH}}=2 \mathrm{~Hz}, \mathrm{H}^{3}{ }^{-}{ }_{\mathrm{bppy}}\right), 7.74\left[\mathrm{~s}, 8 \mathrm{H}, \mathrm{H}_{o}\left(\mathrm{Ar}^{\prime}\right)\right], 7.70$ $\left(\mathrm{dd}, 1 \mathrm{H},{ }^{3} J_{\mathrm{HH}}=6 \mathrm{~Hz},{ }^{4} J_{\mathrm{HH}}=2 \mathrm{~Hz}, \mathrm{H}^{5}-{ }_{\mathrm{b}}^{\mathrm{bpy}}\right), 7.67\left(\mathrm{dd}, 1 \mathrm{H},{ }^{3} J_{\mathrm{HH}}=6 \mathrm{~Hz}\right.$,
${ }^{4} J_{\mathrm{HH}}=2 \mathrm{~Hz}, \mathrm{H}^{5}$ - bpy), 7.57 [s, 4H, $\left.\mathrm{H}_{p}\left(\mathrm{Ar}^{\prime}\right)\right], 2.61$ (s, 3H, NCMe), 1.73 $\left(\mathrm{q}, 2 \mathrm{H},{ }^{3} \mathrm{JHH}_{\mathrm{HH}}=8 \mathrm{~Hz}, \mathrm{CH}_{2}-\mathrm{Et}\right), 1.45\left(\mathrm{~s}, 9 \mathrm{H}\right.$, tert-butyl $\left.{ }^{t} \mathrm{bpy}\right), 1.44(\mathrm{~s}, 9 \mathrm{H}$, tert-butyl ${ }^{t}$ bpy), $1.00\left(\mathrm{t}, 3 \mathrm{H},{ }^{3} \mathrm{~J}_{\mathrm{HH}}=8 \mathrm{~Hz}, \mathrm{CH}_{3}-\mathrm{Et}\right) .{ }^{13} \mathrm{C} \mathrm{NMR}(125 \mathrm{MHz}$, $\left.\mathrm{CD}_{2} \mathrm{Cl}_{2}\right) \delta 166.3,165.9,158.6,153.6,149.1,147.8,125.9,125.4,120.9$, 120.3 ('bpy aromatic), 36.5 (tert-butyl, quaternary, ${ }^{t} \mathrm{bpy}$ ), 30.3 (tert-butyl$\mathrm{CH}_{3},{ }^{t}$ bpy, coincidental overlap), $16.7\left(\mathrm{NCCH}_{3}\right), 4.8\left(\mathrm{CH}_{2}-\mathrm{Et}\right)$, $1.8\left(\mathrm{CH}_{3}-\mathrm{Et}\right) ; 162.3\left(\mathrm{q}, \mathrm{Ar}^{\prime},{ }^{1} J_{\mathrm{B}-\text { Cipso }}=49 \mathrm{~Hz}\right), 135.4\left(\mathrm{Ar}^{\prime}\right), 129.2$ $\left(\mathrm{q}, m-\mathrm{Ar}^{\prime},{ }^{2} J_{\mathrm{C}-\mathrm{F}}=30 \mathrm{~Hz}\right), 125.2\left(\mathrm{q}, \mathrm{Ar}^{\prime},{ }^{2} J_{\mathrm{C}-\mathrm{F}}=272 \mathrm{~Hz}\right), 118.1\left(\mathrm{Ar}^{\prime}\right)$. ${ }^{19} \mathrm{~F}$ NMR $\left(282 \mathrm{MHz}, \mathrm{CD}_{2} \mathrm{Cl}_{2}\right) \delta-64.86\left(\mathrm{~s}, \mathrm{CF}_{3}-\mathrm{Ar}^{\prime}\right)$. Anal. Calcd for $\mathrm{PtBN}_{2} \mathrm{~F}_{24} \mathrm{C}_{60} \mathrm{H}_{41} \mathrm{D}_{3}$ (\%): C 46.43, $\mathrm{H} \mathrm{3.18,} \mathrm{N}$ 3.00; found: $\mathrm{C} 47.06$, H 3.29, N 2.86.

Catalytic Ethylene Hydrophenylation. A representative catalytic reaction is described. [( ${ }^{t}$ bpy $\left.) \mathrm{Pt}(\mathrm{Ph})(\mathrm{THF})\right]\left[\mathrm{BAr}_{4}{ }_{4}\right]$ (1) $(0.049 \mathrm{~g}$, $0.033 \mathrm{mmol}$ ) was dissolved in $12.0 \mathrm{~mL}$ of benzene containing $0.025 \mathrm{~mol} \%$ hexamethylbenzene (HMB) relative to benzene as an internal standard. The reaction mixture was placed in a stainless steel pressure reactor, charged with ethylene, and heated to $100^{\circ} \mathrm{C}$. After 4 and $16 \mathrm{~h}$, the reaction mixture was cooled to room temperature and analyzed by GC/MS. Peak areas of the products and the internal standard were used to calculate product yields. Ethylbenzene production was quantified using linear regression analysis of gas chromatograms of standard samples. A set of five known standards were prepared consisting of $2: 1,3: 1,4: 1,5: 1$, and $6: 1$ molar ratios of ethylbenzene to hexamethylbenzene in benzene. A plot of the peak area ratios versus molar ratios gave a regression line. For the GC/MS system, the slope and correlation coefficient $\left(R^{2}\right)$ for ethylbenzene were 0.53 and 0.98 , respectively. Identical procedures were used to quantify the production of 1,3diethylbenzene, 1,4-diethylbenzene, and 1,2-diethylbenzene. The slope and correlation coefficients $\left(R^{2}\right)$ for these species are $0.56,0.99 ; 0.56$, $0.99 ; 0.52,0.99$, respectively. At a minimum, reactions were performed in triplicate for a given set of conditions.

Determination of Percent Yield for Catalytic Ethylene Hydrophenylation. Complex 1 ( $0.040 \mathrm{~g}, 0.027 \mathrm{mmol})$ was dissolved in $12.0 \mathrm{~mL}$ of benzene containing $0.02 \mathrm{~mol} \% \mathrm{HMB}$ relative to benzene as an internal standard. The reaction mixture was placed inside a stainless steel pressure reactor with a gas buret $(300 \mathrm{~mL})$ attached. The buret was evacuated and backfilled with $\mathrm{N}_{2}$ (three times), evacuated, and pressurized with $\mathrm{C}_{2} \mathrm{H}_{4}(0.4 \mathrm{MPa})$. From the buret, the pressure reactor was charged with ethylene $(0.03 \mathrm{MPa})$. The buret was then evacuated and backfilled with $\mathrm{N}_{2}$ (three times) and pressurized, along with the pressure reactor, with $\mathrm{N}_{2}(0.8 \mathrm{MPa})$. The solution was then heated for $4 \mathrm{~h}$ at $120^{\circ} \mathrm{C}$, cooled to room temperature, and analyzed by GC/MS.

Kinetic Isotope Effect for Catalysis. A representative catalytic reaction is described. $\left[\left({ }^{t} \mathrm{bpy}\right) \mathrm{Pt}(\mathrm{Ph})(\mathrm{THF})\right]\left[\mathrm{BAr}^{\prime}{ }_{4}\right](\mathbf{1})(0.021 \mathrm{~g}, 0.014$ $\mathrm{mmol}$ ) was dissolved in $5.0 \mathrm{~mL}$ of $\mathrm{C}_{6} \mathrm{D}_{6}$ containing $0.025 \mathrm{~mol} \%$ hexamethylbenzene ( $\mathrm{HMB}$ ) relative to $\mathrm{C}_{6} \mathrm{D}_{6}$ as an internal standard. The reaction mixture was placed in a stainless steel pressure reactor, charged with ethylene $(0.1 \mathrm{MPa})$, and heated to $100^{\circ} \mathrm{C}$. After 4 and $16 \mathrm{~h}$, the reaction mixture was cooled to room temperature and analyzed by GC/MS. Peak areas of the products and the internal standard were used to calculate product yields. The reaction was performed five times, and the average TOs of ethylbenzene, diethylbenzenes, and styrene were determined. The catalytic KIE was determined from the ratio of total alkylbenzene TO after $4 \mathrm{~h}$ produced from reaction in $\mathrm{C}_{6} \mathrm{H}_{6}$ versus $\mathrm{C}_{6} \mathrm{D}_{6}$. The reported error is the deviation from multiple experiments.

Kinetics of Benzene $C-D$ Activation as a Function of $C_{6} D_{6}$ Concentration. A representative kinetic experiment is described. Complex 1 (0.071 g, $0.048 \mathrm{mmol}$ ) and hexamethyldisilane (HMDS, $2 \mu \mathrm{L}$ ) an internal standard, were dissolved in $1.3 \mathrm{~mL}$ of $\mathrm{CD}_{2} \mathrm{Cl}_{2}$. The solution was then divided $(0.38 \mathrm{~mL}$ for each sample) and added to three NMR tubes. To each tube was added $\mathrm{C}_{6} \mathrm{D}_{6}(0.040 \mathrm{~mL}, 0.42 \mathrm{mmol})$. The sample was then placed into a temperature-equilibrated $\left(30^{\circ} \mathrm{C}\right) \mathrm{NMR}$ probe. The kinetic runs were performed in triplicate. ${ }^{1} \mathrm{H}$ NMR spectra 
were collected every $10 \mathrm{~min}$ with $16 \mathrm{scans}$ and a $5.0 \mathrm{~s}$ pulse delay. The peaks for complex 1 were integrated against that of HMDS, and from a plot of $\ln \left([1]_{\mathrm{t}}\right)$ vs time (seconds), the rate constants were extracted. The rate of formation of complex 1- $d_{5}$, in the presence of $1.1 \mathrm{M} \mathrm{C}_{6} \mathrm{D}_{6}$, was $2.04(8) \times$ $10^{-4} \mathrm{~s}^{-1}$ with a correlation coefficient $\left(R^{2}\right)$ of $\geq 0.98$ for each plot.

Kinetic Isotope Effect for Stoichiometric Benzene C-H/D Activation. A representative kinetic experiment is described. Complex $1-d_{5}(0.063 \mathrm{~g}, 0.043 \mathrm{mmol}), \mathrm{C}_{6} \mathrm{H}_{6}(0.063 \mathrm{~mL}, 0.71 \mathrm{mmol})$, and HMB $(0.0014 \mathrm{~g})$ were dissolved in $1.4 \mathrm{~mL}$ of $\mathrm{CD}_{2} \mathrm{Cl}_{2}$. The solution was then divided ( $0.40 \mathrm{~mL}$ for each sample) and added to three NMR tubes. The sample was then placed into a temperature-equilibrated $\left(21^{\circ} \mathrm{C}\right) \mathrm{NMR}$ probe. The kinetic runs were performed in triplicate. ${ }^{1} \mathrm{H}$ NMR spectra were collected every $10 \mathrm{~min}$ with $16 \mathrm{scans}$ and a $5.0 \mathrm{~s}$ pulse delay. The peaks for complex 1 were integrated against that of $\mathrm{HMB}$, and from a plot of $\ln \left(1-[1]_{\mathrm{t}} /\left[1-d_{5}\right]_{\mathrm{o}}\right)$ vs time (seconds), the rate constants were extracted. The rate of formation of complex 1 , in the presence of $0.49 \mathrm{M} \mathrm{C}_{6} \mathrm{H}_{6}$, was $7.1(4) \times 10^{-5} \mathrm{~s}^{-1}$ with a correlation coefficient $\left(R^{2}\right)$ of $\geq 0.98$ for each plot. The conversion of 1 to $1-d_{5}$ was monitored under identical conditions, and from a plot of $\ln \left([\mathbf{1}]_{\mathrm{t}}\right)$ vs time (seconds), the rate constants were extracted.. The rate of formation of complex 1- $\boldsymbol{d}_{5}$ was $5.0(3) \times 10^{-5} \mathrm{~s}^{-1}$ with a correlation coefficient $\left(R^{2}\right)$ of $\geq 0.98$ for each plot. From these two reactions, a $\operatorname{KIE}\left(k_{\mathrm{H}} / k_{\mathrm{D}}\right)$ value of $1.4(1)$ was determined.

Catalytic Ethylene Hydrophenylation using 1:1 (v:v) $\mathrm{C}_{6} \mathrm{H}_{6}$ and $\mathrm{C}_{6} \mathrm{D}_{6}$. $\left[\left({ }^{t} \mathrm{bpy}\right) \mathrm{Pt}\left(\mathrm{NC}_{5} \mathrm{~F}_{5}\right)(\mathrm{Ph})\right]\left[\mathrm{BAr}_{4}{ }_{4}\right]$ (2) (0.009 g, $\left.0.006 \mathrm{mmol}\right)$ was dissolved in $2.0 \mathrm{~mL}$ of benzene $\left(1: 1 \mathrm{C}_{6} \mathrm{H}_{6}\right.$ and $\left.\mathrm{C}_{6} \mathrm{D}_{6}\right)$. The reaction mixture was placed in a stainless steel pressure reactor, charged with ethylene $(0.1 \mathrm{MPa})$, and heated to $100^{\circ} \mathrm{C}$. After $16 \mathrm{~h}$, the reaction mixture was cooled to room temperature and analyzed by GC/MS in order to identify the resulting isotopologues of ethylbenzene.

Catalytic Ethylene Hydrophenylation as a Function of the Concentration of $\left[\left({ }^{t} \mathrm{bpy}\right) \mathrm{Pt}(\mathrm{Ph})(\mathrm{THF})\right]\left[\mathrm{BAr}_{4}{ }_{4}\right]$ (1). Solutions $(12 \mathrm{~mL})$ of benzene and $\mathbf{1}(0.001,0.005,0.01,0.015$, and $0.02 \mathrm{~mol} \%$ relative to benzene) containing equimolar amounts of $\mathrm{HMB}$, relative to 1, were placed in stainless steel pressure reactors, charged with ethylene $(0.1 \mathrm{MPa})$, and heated to $100{ }^{\circ} \mathrm{C}$. After $30 \mathrm{~min}$, the reaction mixtures were cooled to room temperature and analyzed by GC/MS. Peak areas of the products and the internal standard were used to calculate product yields. Each reaction was performed in triplicate.

Catalytic Ethylene Hydrophenylation as a Function of Benzene Concentration. A representative experiment is described. Complex $1(0.014 \mathrm{~g}, 0.010 \mathrm{mmol})$, benzene $(8 \mu \mathrm{L})$, and hexamethyldisilane (HMDS, $2 \mu \mathrm{L})$ were dissolved in $\mathrm{NC}_{5} \mathrm{~F}_{5}(292 \mu \mathrm{L})$. The reaction mixture was transferred to a J-Young NMR tube along with an insert tube containing acetone- $d_{6}$. The tube was purged and pressurized with ethylene $(0.1 \mathrm{MPa})$. A ${ }^{1} \mathrm{H}$ NMR spectrum was obtained, and the ethylene concentration was extracted after integration relative to HMDS. The solution was then heated at $100{ }^{\circ} \mathrm{C}$ for $2 \mathrm{~h}$ and cooled to room temperature. An aliquot $(50 \mu \mathrm{L})$ of the reaction mixture and $\mathrm{HMB}$ $(145 \mu \mathrm{L}, 0.0104 \mathrm{M}$ in DCM) were dissolved in DCM $(2 \mathrm{~mL})$ and analyzed by GC/MS. Peak areas of the products and the internal standard were used to calculate product yields.

Catalytic Ethylene Hydrophenylation as a Function of Ethylene Concentration. A representative experiment is described. A solution of complex $1(0.01 \mathrm{~g}, 0.007 \mathrm{mmol})$ and $\mathrm{C}_{6} \mathrm{D}_{6}(2.45 \mathrm{~mL})$ containing $0.025 \mathrm{~mol} \% \mathrm{HMB}$ (relative to $\mathrm{C}_{6} \mathrm{D}_{6}$ ) was distributed $(0.4 \mathrm{~mL})$ among six J-Young NMR tubes. The tubes were purged and pressurized with ethylene $(0.3 \mathrm{MPa})$. The ethylene concentrations were determined after integration of the ethylene signal relative to HMB. The solutions were heated at $100{ }^{\circ} \mathrm{C}$ for $2 \mathrm{~h}$, cooled to room temperature, and analyzed by GC/MS.

Kinetics of Ethylene Insertion. A representative kinetic experiment is described. Complex $1(0.060 \mathrm{~g}, 0.041 \mathrm{mmol})$ and HMDS $(5 \mu \mathrm{L})$, an internal standard, were dissolved in $1.3 \mathrm{~mL}$ of $\mathrm{CD}_{2} \mathrm{Cl}_{2}$. The solution was then divided $(0.25 \mathrm{~mL}$ for each sample) and added to five highpressure NMR tubes. Each tube was degassed with a freeze-pumpthaw cycle, pressurized with $0.1 \mathrm{MPa}$ of ethylene, and cooled to $-78^{\circ} \mathrm{C}$ until it was placed into a temperature-equilibrated $\left(23^{\circ} \mathrm{C}\right) \mathrm{NMR}$ probe. The temperature of the probe was determined by using a sample of methanol- $d_{4}{ }^{104}$ The kinetic runs were performed in triplicate. The concentration of ethylene in solution was determined by integration against the internal standard. ${ }^{1} \mathrm{H}$ NMR spectra were collected every 2 min with 16 scans and a $2.0 \mathrm{~s}$ pulse delay. The product peaks were integrated against that of HMDS, and from a plot of $\ln \left(1-[4]_{t} /[1]_{\mathrm{o}}\right)$ vs time (seconds) were extracted the rate constants. The rate of formation of complex 4, in the presence of $0.1(1) \mathrm{MC}_{2} \mathrm{H}_{4}$, was $1.07(2) \times 10^{-3} \mathrm{~s}^{-1}$ with a correlation coefficient $\left(R^{2}\right)$ of 0.99 for each plot.

Thermolysis of [( ${ }^{t}$ bpy) $\left.\mathrm{Pt}\left(\mathrm{CH}_{2} \mathrm{CH}_{2} \mathrm{Ph}\right)\left(\eta^{2}-\mathrm{C}_{2} \mathrm{H}_{4}\right)\right]\left[\mathrm{BAr}_{4}^{\prime}\right]$ (4) in $\mathrm{C}_{6} \mathrm{H}_{6}$. To a stainless steel pressure reactor were added complex 4 $(0.016 \mathrm{~g}, 0.011 \mathrm{mmol})$ and $1 \mathrm{~mL}$ of benzene (containing $0.1 \mathrm{~mol} \%$ HMB relative to benzene). The reactor was sealed, pressurized with $0.9 \mathrm{MPa}$ of $\mathrm{N}_{2}$, and heated at $100{ }^{\circ} \mathrm{C}$ for $2 \mathrm{~h}$. At that time, the reactor was allowed to cool to room temperature. The reaction mixture was analyzed by GC/MS. Ethylbenzene was detected in $97 \%$ yield along with $\sim 2 \%$ of 1,3-diethylbenzene (no evidence for 1,4- or 1,2-diethylbenzene formation was obtained).

Thermolysis of $\left[\left({ }^{t}\right.\right.$ bpy $\left.) \mathrm{Pt}\left(\mathrm{CH}_{2} \mathrm{CH}_{2} \mathrm{Ph}\right)\left(\eta^{2}-\mathrm{C}_{2} \mathrm{H}_{4}\right)\right]\left[\mathrm{BAr}_{4}{ }_{4}\right]$ (4) in $\mathrm{C}_{6} \mathrm{D}_{6}$. To a screw-cap NMR tube were added complex $4(0.014 \mathrm{~g}$, $0.0094 \mathrm{mmol}$ ) and $0.5 \mathrm{~mL}$ of $\mathrm{C}_{6} \mathrm{D}_{6}$. The reaction mixture was heated at $100{ }^{\circ} \mathrm{C}$ for $1 \mathrm{~h}$, and then analyzed using GC/MS.

Thermolysis of [( ${ }^{t}$ bpy) $\left.\mathrm{Pt}\left(\mathrm{CH}_{2} \mathrm{CH}_{2} \mathrm{Ph}\right)\left(\eta^{2}-\mathrm{C}_{2} \mathrm{H}_{4}\right)\right]\left[\mathrm{BAr}_{4}{ }_{4}\right]$ (4) in $\mathrm{C}_{6} \mathrm{D}_{6}$ with added Lewis Base. To a screw-cap NMR tube were added complex $4(0.020 \mathrm{~g}, 0.014 \mathrm{mmol}), 0.5 \mathrm{~mL}$ of $\mathrm{C}_{6} \mathrm{D}_{6}$, and tetrahydrofuran- $d_{8}$ (100 equiv relative to $4,111 \mu \mathrm{L}$ ). The reaction mixture was heated at $100{ }^{\circ} \mathrm{C}$ for $24 \mathrm{~h}$ and analyzed via $\mathrm{GC} / \mathrm{MS}$.

Thermolysis of $\left[\left({ }^{t} \mathrm{bpy}\right) \mathrm{Pt}\left(\mathrm{CH}_{2} \mathrm{CH}_{2} \mathrm{Ph}-d_{5}\right)\left(\eta^{2}-\mathrm{C}_{2} \mathrm{H}_{4}\right)\right]\left[\mathrm{BAr}{ }_{4}\right]$ $\left(4-d_{5}\right)$ in $C_{6} D_{6}$. To a screw-cap NMR tube were added complex 4- $d_{5}$ $(0.022 \mathrm{~g}, 0.015 \mathrm{mmol})$ and $0.5 \mathrm{~mL}$ of $\mathrm{C}_{6} \mathrm{D}_{6}$. The reaction mixture was heated at $100{ }^{\circ} \mathrm{C}$ for $2 \mathrm{~h}$ and cooled to room temperature. The reaction mixture was analyzed by GC/MS.

Thermolysis of $\left[\left({ }^{t} \mathrm{bpy}\right) \mathrm{Pt}\left(\mathrm{CH}_{2} \mathrm{CH}_{2} \mathrm{Ph}-d_{5}\right)\left(\eta^{2}-\mathrm{C}_{2} \mathrm{H}_{4}\right)\right]\left[\mathrm{BAr}^{\prime}{ }_{4}\right]$ $\left(4-d_{5}\right)$ in $\mathrm{C}_{6} \mathrm{H}_{6}$. To a screw-cap NMR tube were added complex 4- $d_{5}$ $(0.018 \mathrm{~g}, 0.012 \mathrm{mmol})$ and $0.5 \mathrm{~mL}$ of $\mathrm{C}_{6} \mathrm{H}_{6}$. The reaction mixture was heated at $100{ }^{\circ} \mathrm{C}$ for $2 \mathrm{~h}$ and cooled to room temperature. The reaction mixture was analyzed by GC/MS.

Thermolysis of $\left[\left({ }^{t} \mathrm{bpy}\right) \mathrm{Pt}\left(\mathrm{CH}_{2} \mathrm{CH}_{2} \mathrm{Ph}-d_{5}\right)\left(\eta^{2}-\mathrm{C}_{2} \mathrm{H}_{4}\right)\right]\left[\mathrm{BAr}{ }_{4}\right]$ $\left(4-d_{5}\right)$ in $C_{6} D_{6}$ with added Lewis Base. To a screw-cap NMR tube were added complex 4- $d_{5}(0.022 \mathrm{~g}, 0.015 \mathrm{mmol}), 0.5 \mathrm{~mL}$ of $\mathrm{C}_{6} \mathrm{H}_{6}$, and tetrahydrofuran (100 equiv relative to $4-d_{5}, 120 \mu \mathrm{L}$ ). The reaction mixture was heated at $100{ }^{\circ} \mathrm{C}$ for $2 \mathrm{~h}$, and analyzed via GC/MS.

Variable-Temperature ${ }^{1} \mathrm{H}$ NMR of $\left[\left({ }^{t}\right.\right.$ bpy $) \mathrm{Pt}\left(\mathrm{CH}_{2} \mathrm{CH}_{2} \mathrm{Ph}\right)-$ $\left.\left(\eta^{2}-\mathrm{C}_{2} \mathrm{H}_{4}\right)\right]\left[\mathrm{BAr}_{4}^{\prime}\right](4)$. A sample of $\left[\left({ }^{t} \mathrm{bpy}\right) \mathrm{Pt}\left(\mathrm{CH}_{2} \mathrm{CH}_{2} \mathrm{Ph}\right)\left(\eta^{2}-\mathrm{C}_{2} \mathrm{H}_{4}\right)\right]$ $\left[\left(\mathrm{BAr}_{4}^{\prime}\right)\right]$ in $\mathrm{CD}_{2} \mathrm{Cl}_{2}$ was placed in a Varian $500 \mathrm{MHz}$ spectrometer. The temperature was cooled incrementally down to $-80{ }^{\circ} \mathrm{C}$, and ${ }^{1} \mathrm{H}$ NMR spectra were acquired after several minutes at each temperature to allow for equilibration. Temperatures were calibrated using a methanol- $d_{4}$ standard.

Variable-Temperature ${ }^{1} \mathrm{H}$ NMR of [( ${ }^{t}$ bpy $) \mathrm{Pt}\left(\mathrm{CH}_{2} \mathrm{CH}_{2} \mathrm{Ph}\right)-$ $\left.\left(\eta^{2}-\mathrm{C}_{2} \mathrm{H}_{4}\right)\right]\left[\mathrm{BAr}_{4}^{\prime}\right](4)$ in the Presence of Free Ethylene. $\mathrm{A}^{1} \mathrm{H}$ NMR spectrum of a solution of 4 in $\mathrm{CD}_{2} \mathrm{Cl}_{2}$ with an internal $\mathrm{HMB}$ standard was acquired on a Varian $500 \mathrm{MHz}$ spectrometer. The solution was then charged with ethylene by bubbling into a screw-cap NMR tube. Acquisition of a ${ }^{1} \mathrm{H}$ NMR spectrum revealed a single coalesced resonance $(4.77 \mathrm{ppm})$ for coordinated and free ethylene. Cooling the NMR probe to $-90{ }^{\circ} \mathrm{C}$ did not result in decoalescence of the resonances. 


\section{ASSOCIATED CONTENT}

S Supporting Information. Crystallographic and GC/MS data, additional experimental details, computational details, and complete reference 103 (as reference 6). This material is available free of charge via the Internet at http://pubs.acs.org.

\section{AUTHOR INFORMATION}

\section{Corresponding Author}

tbg7h@virginia.edu; t@unt.edu

\section{ACKNOWLEDGMENT}

T.B.G. and T.R.C. acknowledge The Office of Basic Energy Sciences, U.S. Department of Energy for support of this work (DE-SC0000776 and DE-FG02-03ER15387). T.R.C. thanks the NSF (CHE-0741936) for facility support. We also thank Professor Mahdi Abu-Omar from Purdue University for useful discussion.

\section{REFERENCES}

(1) Goj, L. A.; Gunnoe, T. B. Curr. Org. Chem. 2005, 9, 671-685.

(2) Roberts, R. M.; Khalaf, A. A. Friedel-Crafts Alkylation Chemistry: A Century of Discovery; Marcel Dekker, Inc.: New York, 1984.

(3) Olah, G. A.; Molnar, A. Hydrocarbon Chemistry; Wiley-Interscience: New York, 1995.

(4) Perego, C.; Ingallina, P. Green Chem. 2004, 6, 274-279.

(5) Degnan, J., T. F.; Smith, C. M.; Venkat, C. R. Appl. Catal., A 2001, 221, 283-294.

(6) Corma, A.; García, H. Chem. Rev. 2003, 103, 4307-4365.

(7) Cejka, J.; Wichterlova, B. Catal. Rev. 2002, 44, 375-421.

(8) Kocal, J. A.; Vora, B. V.; Imai, T. Appl. Catal., A 2001, 221, 295-301.

(9) Bejblová, M.; Žilková, N.; Čejka, J. Res. Chem. Intermed. 2008, 34, 439-454.

(10) Vora, B. V.; Pujado, P. R.; Imai, T.; Fritsch, T. R. Tenside, Surfact., Deterg. 1991, 28, 287-294.

(11) Perego, C.; Ingallina, P. Catal. Today 2002, 73, 3-22.

(12) Jia, C.; Piao, D.; Oyamada, J.; Lu, W.; Kitamura, T.; Fujiwara, Y. Science 2000, 287, 1992-1995.

(13) Widenhoefer, R. A. Unactivated Alkenes. In Catalytic Asymmetric Friedel-Crafts Alkylations; Bandini, M., Umani-Ronchi, A., Eds.; Wiley-VCH GmbH \& Co. KGaA: Weinheim, 2009; pp 203-222.

(14) Jia, C.; Kitamura, T.; Fujiwara, Y. Acc. Chem. Res. 2001, 34, 633-639.

(15) Kakiuchi, F.; Murai, S. Acc. Chem. Res. 2002, 35, 826-834.

(16) Ritleng, V.; Sirlin, C.; Pfeffer, M. Chem. Rev. 2002, 102, 17311769

(17) Colby, D. A.; Bergman, R. G.; Ellman, J. A. Chem. Rev. 2009, $110,624-655$.

(18) Lail, M.; Bell, C. M.; Conner, D.; Cundari, T. R.; Gunnoe, T. B.; Petersen, J. L. Organometallics 2004, 23, 5007-5020.

(19) Foley, N. A.; Lee, J. P.; Ke, Z.; Gunnoe, T. B.; Cundari, T. R. Acc. Chem. Res. 2009, 42, 585-597.

(20) Matsumoto, T.; Taube, D. J.; Periana, R. A.; Taube, H.; Yoshida, H. J. Am. Chem. Soc. 2000, 122, 7414-7415.

(21) Luedtke, A. T.; Goldberg, K. I. Angew. Chem., Int. Ed. 2008, 47, 7694-7696.

(22) Karshtedt, D.; Bell, A. T.; Tilley, T. D. Organometallics 2004, 23, 4169-4171.

(23) Lail, M.; Arrowood, B. N.; Gunnoe, T. B. J. Am. Chem. Soc. 2003, 125, 7506-7507.

(24) Foley, N. A.; Lail, M.; Gunnoe, T. B.; Cundari, T. R.; Boyle, P. D.; Petersen, J. L. Organometallics 2007, 26, 5507-5516.
(25) Foley, N. A.; Lail, M.; Lee, J. P.; Gunnoe, T. B.; Cundari, T. R.; Petersen, J. L. J. Am. Chem. Soc. 2007, 129, 6765-6781.

(26) Andreatta, J. R.; McKeown, B. A.; Gunnoe, T. B. J. Organomet. Chem. 2011, 696, 305-315.

(27) Oxgaard, J.; Periana, R. A.; Goddard, W. A., III. J. Am. Chem. Soc. 2004, 126, 11658-11665.

(28) Oxgaard, J.; Muller, R. P.; Goddard, W. A., III; Periana, R. A. J. Am. Chem. Soc. 2004, 126, 352-363.

(29) Karshtedt, D.; McBee, J. L.; Bell, A. T.; Tilley, T. D. Organometallics 2006, 25, 1801-1811.

(30) Bowring, M. A.; Bergman, R. G.; Tilley, T. D. Organometallics 2011, 30, 1295-1298.

(31) Foley, N. A.; Gunnoe, T. B.; Cundari, T. R.; Boyle, P. D.; Petersen, J. L. Angew. Chem., Int. Ed. 2007, 47, 726-730.

(32) Johansson, L.; Tilset, M.; Labinger, J. A.; Bercaw, J. E. J. Am. Chem. Soc. 2000, 122, 10846-10855.

(33) Zhong, H. A.; Labinger, J. A.; Bercaw, J. E. J. Am. Chem. Soc. 2002, 124, 1378-1399.

(34) Heyduk, A. F.; Driver, T. G.; Labinger, J. A.; Bercaw, J. E. J. Am. Chem. Soc. 2004, 126, 15034-15035.

(35) Wik, B. J.; Lersch, M.; Krivokapic, A.; Tilset, M. J. Am. Chem. Soc. 2006, 128, 2682-2696.

(36) Zhang, F. B.; Kirby, C. W.; Hairsine, D. W.; Jennings, M. C.; Puddephatt, R. J. J. Am. Chem. Soc. 2005, 127, 14196-14197.

(37) Reinartz, S.; White, P. S.; Brookhart, M.; Templeton, J. L. J. Am. Chem. Soc. 2001, 123, 12724-12725.

(38) Wick, D. D.; Goldberg, K. I. J. Am. Chem. Soc. 1997, 119, 10235-10236.

(39) Johansson, L.; Tilset, M. J. Am. Chem. Soc. 2001, 123, 739-740.

(40) Johansson, L.; Ryan, O. B.; Romming, C.; Tilset, M. J. Am. Chem. Soc. 2001, 123, 6579-6590.

(41) Lersch, M.; Tilset, M. Chem. Rev. 2005, 105, 2471-2526.

(42) MacDonald, M. G.; Kostelansky, C. N.; White, P. S.; Templeton, J. L. Organometallics 2006, 25, 4560-4570.

(43) McKeown, B. A.; Foley, N. A.; Lee, J. P.; Gunnoe, T. B. Organometallics 2008, 27, 4031-4033.

(44) Ong, C. M.; Jennings, M. C.; Puddephatt, R. J. Can. J. Chem. 2003, 81, 1196-1205.

(45) Shiotsuki, M.; White, P. S.; Brookhart, M.; Templeton, J. L. J. Am. Chem. Soc. 2007, 129, 4058-4067.

(46) Chen, G. S.; Labinger, J. A.; Bercaw, J. E. Proc. Natl. Acad. Sci. U.S.A. 2007, 104, 6915-6920.

(47) Owen, J. S.; Labinger, J. A.; Bercaw, J. E. J. Am. Chem. Soc. 2006, 128, 2005-2016.

(48) Janowicz, A. H.; Bergman, R. G. J. Am. Chem. Soc. 1983, 105, 3929-3939.

(49) Periana, R. A.; Bergman, R. G. J. Am. Chem. Soc. 1986, 108, $7332-7346$.

(50) Northcutt, T. O.; Wick, D. D.; Vetter, A. J.; Jones, W. D. J. Am. Chem. Soc. 2001, 123, 7257-7270.

(51) Vetter, A. J.; Flaschenriem, C.; Jones, W. D. J. Am. Chem. Soc. 2005, 127, 12315-12322.

(52) Jordan, R. Reaction Mechanisms of Inorganic and Organometallic Systems; Oxford University Press: New York, 1991.

(53) Shilov, A. E.; Shul'pin, G. B. Chem. Rev. 1997, 97, 2879-2932.

(54) Shilov, A. E.; Shul'pin, G. B. Activation and Catalytic Reactions of Saturated Hydrocarbons in the Presence of Metal Complexes; Kluwer Academic Publishers: New York, 2002.

(55) Li, J.-L.; Geng, C.-Y.; Huang, X.-R.; Zhang, X.; Sun, C.-C. Organometallics 2007, 26, 2203-2210.

(56) Stahl, S. S.; Labinger, J. A.; Bercaw, J. E. J. Am. Chem. Soc. 1996, 118, 5961-5976.

(57) Wik, B. J.; Lersch, M.; Tilset, M. J. Am. Chem. Soc. 2002, 124, 12116-12117.

(58) Hill, G. S.; Rendina, L. M.; Puddephatt, R. J. Organometallics 1995, 14, 4966-4968.

(59) Driver, T. G.; Day, M. W.; Labinger, J. A.; Bercaw, J. E. Organometallics 2005, 24, 3644-3654. 
(60) Parmene, J.; Ivanovic-Burmazovic, I.; Tilset, M.; van Eldik, R. Inorg. Chem. 2009, 48, 9092-9103.

(61) Oxgaard, J.; Tenn, III, W. J.; Nielson, R. J.; Periana, R. A.; Goddard, W. A., III. Organometallics 2007, 26, 1565-1567.

(62) Boutadla, Y.; Davies, D. L.; Macgregor, S. A.; PobladorBahamonde, A. I. J. Chem. Soc., Dalton Trans. 2009, 5820-5831.

(63) Perutz, R. N.; Sabo-Etienne, S. Angew. Chem., Int. Ed. 2007, $46,2578-2592$.

(64) Vastine, B. A.; Hall, M. B. J. Am. Chem. Soc. 2007, 129, 1206812069.

(65) Lam, W. H.; Jia, G.; Lin, Z.; Lau, C. P.; Eisenstein, O. Chem.Eur. J. 2003, 9, 2775-2782.

(66) Feng, Y.; Lail, M.; Foley, N. A.; Gunnoe, T. B.; Barakat, K. A.; Cundari, T. R.; Petersen, J. L. J. Am. Chem. Soc. 2006, 128, 7982-7994.

(67) DeYonker, N. J.; Foley, N. A.; Cundari, T. R.; Gunnoe, T. B.; Petersen, J. L. Organometallics 2007, 26, 6604-6611.

(68) Campbell, A. N.; Gagne, M. R. Organometallics 2007, 26, 27882790.

(69) Nakata, N.; Fukazawa, S.; Ishii, A. Organometallics 2009, 28, 534-538.

(70) Ittel, S. D.; Johnson, L. K.; Brookhart, M. Chem. Rev. 2000, 100, 1169-1204.

(71) Albano, V. G.; Demartin, F.; De Renzi, A.; Morelli, G.; Saporito, A. Inorg. Chem. 1985, 24, 2032-2039.

(72) Cucciolito, M. E.; De Felice, V.; Panunzi, A.; Vitagliano, A. Organometallics 1989, 8, 1180-1187.

(73) De Renzi, A.; Di Blasio, B.; Saporito, A.; Scalone, M.; Vitagliano, A. Inorg. Chem. 1980, 19, 960-966.

(74) De Felice, V.; Cucciolito, M. E.; De Renzi, A.; Ruffo, F.; Tesauro, D. J. Organomet. Chem. 1995, 493, 1-11.

(75) De Felice, V.; De Renzi, A.; Tesauro, D.; Vitagliano, A. Organometallics 1992, 11, 3669-3676.

(76) Albano, V. G.; Braga, D.; De Felice, V.; Panunzi, A.; Vitagliano, A. Organometallics 1987, 6, 517-525.

(77) Cucciolito, M. E.; De Renzi, A.; Orabona, I.; Ruffo, F.; Tesauro, D. J. Chem. Soc., Dalton Trans. 1998, 1675-1678.

(78) Ganis, P.; Orabona, I.; Ruffo, F.; Vitagliano, A. Organometallics 1998, 17, 2646-2650.

(79) Fusto, M.; Giordano, F.; Orabona, I.; Ruffo, F.; Panunzi, A. Organometallics 1997, 16, 5981-5987.

(80) Herzberg, G. Electronic Spectra and Electronic Structure of Polyatomic Molecules; Van Nostrand: New York, 1966.

(81) Helm, L.; Merbach, A. E. Chem. Rev. 2005, 105, 1923-1960.

(82) Cucciolito, M. E.; D’Amora, A.; Tuzi, A.; Vitagliano, A. Organometallics 2007, 26, 5216-5223.

(83) King, E. L.; Altman, C. J. Phys. Chem. 1956, 60, 1375-1378.

(84) De Felice, V.; De Renzi, A.; Tesauro, D.; Vitagliano, A. Organometallics 1992, 11, 3669-3676.

(85) Plutino, M. R.; Fenech, L.; Stoccoro, S.; Rizzato, S.; Castellano, C.; Albinati, A. Inorg. Chem. 2010, 49, 407-418.

(86) Crabtree, R. H.; Mellea, M. F.; Quirk, J. M. J. Am. Chem. Soc. 1984, 106, 2913-2917.

(87) Bernskoetter, W. H.; Schauer, C. K.; Goldberg, K.; Brookhart, M. Science 2009, 326, 553-556.

(88) Jensen, M. P.; Wick, D. D.; Reinartz, S.; White, P. S.; Templeton, J. L.; Goldberg, K. I. J. Am. Chem. Soc. 2003, 125, 8614-8624.

(89) Lo, H. C.; Haskel, A.; Kapon, M.; Keinan, E. J. Am. Chem. Soc. 2002, 124, 3226-3228.

(90) Jones, W. D. Acc. Chem. Res. 2003, 36, 140-146.

(91) Brookhart, M.; Grant, B.; Volpe, A. F. Organometallics 2002, 11, 3920-3922.

(92) Tanko, J. M.; Drumright, R. E. J. Am. Chem. Soc. 2002, 114, 1844-1854.

(93) Becke, A. D. J. Chem. Phys. 1993, 98, 5648-5652.

(94) Becke, A. D. J. Chem. Phys. 1993, 98, 1372-1377.

(95) Miehlich, B.; Savin, A.; Stoll, H.; Heinzwerner, P. Chem. Phys. Lett. 1989, 157, 200-206.
(96) Cundari, T. R.; Stevens, W. J. J. Chem. Phys. 1993, 98, 55555565

(97) Lee, C.; Yang, W.; Parr, R. G. Phys. Rev. B 1988, 37, 785-789.

(98) Stevens, W. J.; Basch, H.; Krauss, M. J. Chem. Phys. 1984, 81, 6026-6033.

(99) Stevens, W. J.; Krauss, M.; Basch, H.; Jasien, P. G. Can. J. Chem. 1992, 70, 612-630.

(100) Barone, V.; Cossi, M.; Tomasi, J. J. Comput. Chem. 1998, 19, 404-417.

(101) Barone, V.; Cossi, M. J. Phys. Chem. A 1998, 102, 1995-2001.

(102) Cossi, M.; Rega, N.; Scalmani, G.; Barone, V. J. Comput. Chem. 2003, 24, 669-681.

(103) Frisch, M. J., et al. Gaussian 03, Revision C.02; Gaussian, Inc.: Wallingford, CT, 200.

(104) The temperature was verified using the following equation provided by experimental data from the University of Nebraska (2001): $T(\mathrm{~K})=-23.1902 x^{2}-31.1062 x+399.081$, where $x=$ ppm(OD) vs $\operatorname{ppm}\left(\mathrm{CD}_{3}\right)$. 